

\section{Please}

handle this volume with care.

The University of Connecticut Libraries, Storrs

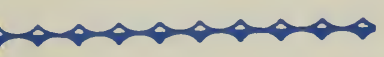

\subsection{3}

$\sqrt{2} 213 y$

$8503, v .3$

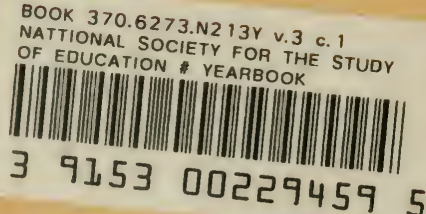





\title{
THE THIRD YEARBOOK
}

OF THE

\section{NATIONAL SOCIETY FOR THE SCIEN- TIFIC STUDY OF EDUCATION}

\author{
PART II \\ NATURE-STUDY \\ BY \\ W I L B UR S. JACK M A N \\ The University of Chicago
}

EDITED BY

MANFRED J. HOLMES

MEETINGS FOR THE DISCUSSION OF THIS PAPER WILL BE HELD AT 4:00 P. M., MONDAY, JUNE 27, AND AT 4:30 P. M., TUESDAY, JUNE 28, I904, ROOM I, HALL OF CONGRESSES, WORLD'S FAIR GROUNDS, ST. LOUIS 
COPYRIGHT, I904, BY

MANFRED J H L L ES

Chicago, Illinois 
This YeArbook brings before the National Society a timely and valuable contribution dealing with one of the most vital problems of the elementary course of study.

Professor Jackman is a well-known pioneer and leader in naturestudy, and what he says on the subject will command the attention of all serious students of the elementary-school problem.

There will no doubt be a large attendance of active members at our St. Louis meetings, and it is urged that each member make a careful study of the paper beforehand. Experience shows clearly that such preliminary study is necessary to appreciation and fair treatment of the author, and that without it our meetings cannot yield their highest value.

It is probably the unanimous voice of the members of the Society that the discussion should be on the paper, and that those who have studied it should be given preference in discussion. Carefully prepared discussions will be valuable for the YEARBook.

It will do much to extend and carry out the work of the Society if members will form local round tables for the study of the problems discussed in the Yearbooks. Such local circles can get extra books at a reduction of one-fifth the retail price by sending directly to The University of Chicago Press.

Election of active members and other business will be transacted at the Tuesday meeting. The time for this second meeting can be changed, if necessary, to meet the convenience of the members present.

At one of the meetings time will be given to the reception of fiveto ten-minute reports from active members setting forth some specific problem they are at work upon, showing method of attacking the problem, and indicating results when results have been reached. These reports ought to be of value in several ways; but first of all they will show the extent to which scientific spirit and method are found in the educational field, so far as the members of the National Society represent that field.

It is believed that these written reports will be one of the most interesting features of our programs, and, at the discretion of the Executive Committee, may be printed in the Yearbook. Any member having such report, but being unable to attend the meetings, is requested to send it to the Secretary. 


\section{OFFICERS AND EXECUTIVE COMMITTEE.}

Wilbur S. Jackman, University of Chicago, President.

Charles DeGarmo, Cornell University, Ithaca, N. Y.

Charles P. Cary, State Superintendent, Madison, Wis.

Reuben Post Halleck, Male High School, Louisville, Ky.

Chiarles A. McMurry, Northern Illinois State Normal School, DeKalb, Ill.

Manfred J. Holmes, Illinois State Normal University, Normal, I1l., Secretary-Treasurer. 


\section{TABLE OF CONTENTS.}

FOREWORD

Chapter I. Introduction

I. Nature-Study - Its General Meaning - - - - -

2. The Unity of Nature-Study and Natural Science - - - $\quad$ II

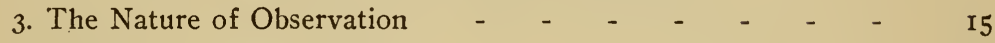

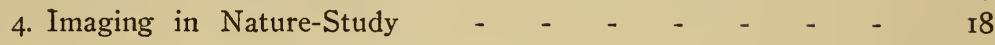

Chapter II. The Scope of Nature-Study - - - - - $\quad$ - 22-43

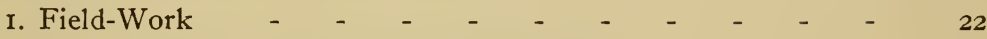

2. Nature-Study and Man in the Landscape - $\quad$ - $\quad$ - $\quad 27$

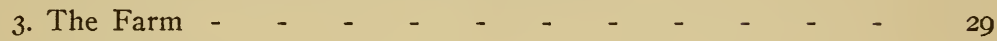

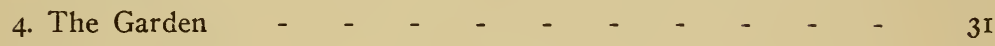

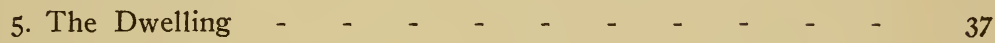

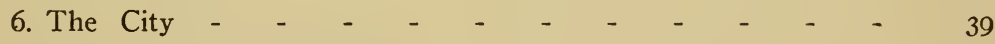

7. Nature-Study and History - $\quad-\quad-\quad-\quad-\quad-\quad-\quad-\quad 4 \mathrm{r}$

Chapter III. 'The Study of Individuals versus That of Types - 44-49

Chapter IV. Nature-Study and Expression - - - - - 50-64

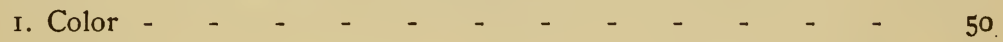

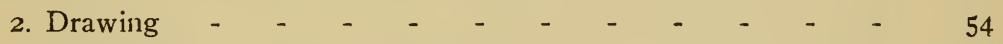

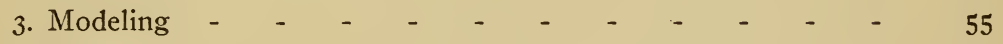

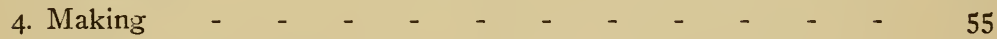

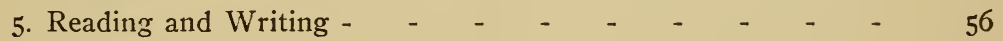

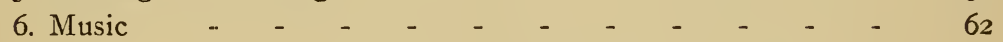

Chapter V. Number-Work in Nature-Study - - - - - 65-72

I. Dispersal of Seeds - $\quad$ - $\quad$ - $\quad$ - $\quad$ - $\quad$ - $\quad$ - $\quad$ - $\quad$ - 69

2. Seasonal Conditions: Were They Favorable or Unfavorable? 70 Chapter Vi. Nature-Study and Morals - - - - $\quad$ 73-8I Appendix A. A Record in Nature-Study - - - - $\quad$ - 82-83 Appendix B. Course of Study - $\quad$ - $\quad$ - $\quad$ - $\quad$ - $\quad$ - $\quad$ - $\quad$ - 84-96 Minutes of Meetings Held at Atlanta, Ga., February 22-25, 1904 97-99 List of Active Members - 



\section{FOREWORD.}

In placing this contribution before the Society, it is deemed necessary to offer a word of explanation as to form and content. Naturestudy is not a matter that can be argued into the schools, nor can it be established by tumbling down upon them a great load of miscellaneous facts. Neither can it ever play any important part in education while it is treated as a thing in itself. This monograph has been prepared, therefore, with three points in mind: (I) that naturestudy must be presented in accordance with the general principles of psychology which apply to all other subjects ; (2) by a few illustrations, to show how it is necessary to start with great general views or pictures of nature and to proceed gradually to the details, thus enabling the mind as it grows, to organize the facts, the lesser under the greater, at every step; (3) that nature-study forms but a part of the educational work; its relationships reach into all other subjects which go to make up the whole. The aim has been to emphasize these points by stating reasons, without entering upon exhaustive arguments; by suggesting salient centers of subject-matter, without becoming submerged in minute details; by dealing with the principles of method, without prolonging a discussion of devices; and, finally, by carrying through the whole a due regard for the needs of the young and growing mind, and a proper consideration for its methods and modes of development.

The paper embodies the best results of the author's experience of several years of teaching the subject, and he will be only too happy if it calls forth from his colleagues and many friends a discussion that will point the way to better things. 



\section{THE THIRD YEARBOOK}

\section{NATURE-STUDY.}

\section{CHAPTER I.}

INTRODUCTION.

\section{NATURE-STUDY: ITS GENERAL MEANING.}

THE spirit of nature-study requires that the pupils be intelligently directed in the study of their immediate environment in its relation to themselves; that there shall be, under the natural stimulus of the desire to know, a constant effort at a rational interpretation of the common things observed. If this plan be consistently pursued, it will naturally follow that the real knowledge acquired, the trustworthy methods developed, and the correct habits of observing and imaging formed will lay a sound foundation for the expansive scientific study which gradually creates a world-picture, and at the same time enables the student, by means of the microscope, the dissecting knife and the alembic, to penetrate intelligently into its minute details.

The study of nature ultimately resolves itself into a study of energy. The great aspects under which energy may be observedcolor, form, and force-are presented to the children through an inquiry into their functions.

In nature-study as in everything else, the work must begin with what the individual has already acquired, and it should proceed from this according to the natural laws of mind-growth. The pupil's knowledge of nature, which must be recognized as the basis for further study, has been gathered by a more or less careful observation of his surrounding landscape. The function of the teacher is to assist the learner through experiment, and by following the suggestions derived from experience in an elaboration of the details of this great indefinite picture. If properly conducted, the study will lead to a fuller recognition of natural laws which are simply the statement of the sequence of phenomena, that, so far as observed, remains constant. 
It is a fact of tremendous import for teachers to remember that there can be no rational observation of anything that is not stimulated and guided by the suggestion of law. This is true whether the pupil is a child or an adult. Failure to understand the importance of this point is responsible for the unspeakable confusion which now exists in most teachers' minds regarding the selection and presentation of material in nature-study. The examination by children into the minute details of a subject is not only a physical impossibility, but it is also an absurdity, for the simple reason that for them through these minutiæ there can be no manifestation of law. Illustrations are abundant. The older botany, when tried with the children, failed for precisely this reason. The children could see, physically, the venation, margin, shape, etc., of leaves; but their work fell below true observation, and consequently interest died out, because as presented, no reason or law suggested itself in explanation of these facts. When the same facts are reached through a broad presentation of the plant's relations to light, heat, and moisture, they at once become true and interesting objects of observation and fruitful sources of thought, because the perceived relationships suggest reasons that explain them. The same is true whatever may be the aspect of presentation-that of beauty as well as that of use. For the idea of beauty rests finally upon the perception of fitness, of adaptation; and adaptation points to the statement of a law.

It must not be supposed that it is here maintained that everything done in nature-study should lead at once to an actual formulation of law. This would be manifestly impossible and absurd. Many things are under observation at present for which the wisest cannot state the law but it is their suggestion in that direction that preserves interest in the study. The sweep of the seasons is a fact that may be so presented to children that its hint of law will stimulate active observation and thought long before any formula for it can be stated.

The region of nature is for the child, as for the savage and the ignorant man, a domain of mystery and of fancy. The aim of the teacher should be so to present nature and its various manifestations that the reasonableness of things shall appear. The pupil must be trained to see things, as nearly as he can, as they actually exist, and not as though he were intoxicated or insane or in a delirium. 
There is no reason to fear that this will rob anyone of his enjoyment of nature, or that it will reduce it at one stroke to the level of the prosaic. Truth in science is always more splendid than fiction, and the pictures developed by the imagination out of real conditions always eclipse those that are conjured up by flights of fancy.

\section{THE UNITY OF NATURE-STUDY AND NATURAL SCIENCE.}

In a general survey of the place and functions of nature-study it is quite important that its relation to the more technical branches of natural science should be duly considered. For the purpose of properly defining a subject it may be necessary to set it apart in a state of isolation and to place the emphasis upon its differences; but for finding the full measure of its usefulness it is of far greater importance to discover its true relations.

What seems to be an almost inherent tendency of the human being to worship the abstruse, the mystical, and the learned has never been more amusingly exemplified than in the disposition of many of those who call themselves scientists to disown nature-study and to deny that it bears any particularly useful relation to their own special subjects. This refusal to recognize nature-study as a part of science, and the denial that its methods are distinctly scientific, have done much to discredit the subject in the eyes of teachers and pupils and the public at large.

The objections as urged may have been valid, in some degree, against the crude and rudimentary methods employed in the beginning; these nature-study itself disowns. But they cannot be successfully maintained against the study when it is properly conducted. That nature-study is the forerunner, the direct progenitor, of natural science is a perfectly obvious and most helpful truth to anyone who will fairly consider the matter and the methods of both.

Nature-study is precisely what it proclaims itself to be-the study of nature. Its subject-matter lies in the kingdoms of earth, air, sky, and water; it embraces a search for knowledge of all phenomena and of the laws by which these are associated. Natural science finds all of its subject-matter in the same fields, and it pursues its course toward the same end.

In nature-study everything depends primarily upon the integrity and the proper use of the senses. Knowledge becomes clear and 
trustworthy exactly in proportion to the accuracy with which the senses furnish the data. Natural science is dependent upon the same organs and upon data obtained by precisely the same means.

In nature-study the value of the subject to the individual depends upon his own observation and investigation. The original and personal character of these determine the rate and amount of progress that an individual can make. It is this point, too, that is strongly insisted upon in natural science. Everything is open to question by everyone. Nothing is necessarily assured simply because someone else has claimed to have made the observation.

In nature-study the aim is to have the pupil investigate phenomena and things for the purpose of determining their relation. Nothing is studied in isolation. By such methods certain relationships are discovered to be constant and the pupil early gets the clue to the meaning of natural law. In natural science the aim is the same; the student seeks then the study of natural phenomena for those abiding relations, those sequences of cause and effect, the expression of which becomes the statement of natural law. The determination of the constant, hence natural, order of phenomena is the ultimate end of all study. It is the task of the scientist, the historian, the philosopher alike, and nature-study represents but a primary stage of the same thing. There is no actual dividing line, therefore, between the pupil in nature-study and the student of natural science. The motive, the material, and the principles of method are precisely the same. In practical instruction, however, the characteristic differences are encountered in teaching these subjects to pupils of different ages that are met with in other studies of the curriculum.

In nature-study with children the teacher has to deal with untrained senses and with mental powers generally undeveloped. The pupil is unable either to see great detail or to grasp relationships that exist among the minutiæ of the subject. As the story told by the pupil's senses is vague and inaccurate so the pictures of his incipient imagination are erratic and fanciful. He must therefore deal with larger masses than are necessary with the trained student of science. The sights must be more vivid, the weights heavier, the relations more striking, the movements more pronounced, and the functions more obvious. In natural science the better-trained student discovers minute details and recognizes more 
delicate relations. It is upon these facts that a true system of gradation in nature-study and science must rest. The attempt is usually made to establish grades by changing from one branch of the science to another and by the introduction of new and often unrelated subject-matter. This is done partially on the theory that repetition of the same thing becomes tiresome, which is true, and partially on the theory that, to keep alive the interest, the subject must be changed, which is not true. Nothing could be more detrimental to the genuine development of the pupil than the continual snapping of his thread of interest which is involved in the customary plans of gradation. The materials and phenomena of nature as subject-matter for study do not in themselves actually change; the continual and growing interest in the same thing, therefore, must always be preserved.

Nor is the distinction between nature-study and science, sometimes made, that the results in the latter may be more quantitative than in the former, a valid one. Such results in nature-study are possible and proper in any particular field when the student of science would find them desirable, and necessary. For example, in all study of physical force there is but one line open to the student who attempts to investigate, whether he is six years old or sixty, and that is to find out its value; this can be done only by measuring it.

The pupil very soon exhausts the qualitative aspects of such a subject, if indeed he has not already done so before he enters school. By this it is not meant that the pupil from the beginning must be asked to run down the result to the last decimal point in an indefinite series. In the outset it may involve none of the usual units at all. He may get the result in terms of which he can himself lift or push or pull, or otherwise physically accomplish. It is only then that he actually finds the need of the unit, pound, foot, gallon, etc.; it is as these gradually become definite in his mind that the fractional part has any value to hin.

Where the average student of science might be able to develop the picture he seeks by the analysis of a single leaf, or of a drop of water, or of an ounce of earth, the beginner in nature-study must use bushels, gallons, or pounds. There are two reasons for this: first, the pupil's undeveloped imagination must picture in the large - he cannot think in grains of sand; and second, because, unskilled in manipulation, the liability to losses during experimentation with 
the small quantities, enormously increases the percentage of error. True nature-study, therefore, is natural science, and its methods are strictly scientific.

It is not here sought to establish merely an identity of terms. Failure to recognize the true relation of the different parts of the subject has helped to emphasize the break that is already too pronounced between the elementary and the higher schools. Believing that there is some radical difference, the high-school teachers, as a rule, make but little effort to prepare a course of study that substantially continues the work of nature-study. The consequent abrupt change of method and material simply adds to the loss that the pupil suffers in other directions in this transition stage. The study of nature is the same, regardless of the age of the student. It will be a great step in advance when all teachers recognize this, and so plan the course of study that the pupil will not find it necessary to unlearn, ignore, or forget what he has learned in earlier stages. Every step taken should be a substantial preparation for the next throughout the course from the kindergarten to the university. This plan would also immensely strengthen the elementary teachers, and give stability, tone, and dignity to the work that it has seldom yet assumed. No teacher can put the best into his work when he feels that he is engaged simply in "busy work," which must serve as entertainment, at least, for the moment. It is not so in other subjects, and this fact contributes not a little to the strength of the position they hold in the curriculum. Every scrap of history, for example, that the pupil learns anywhere in his course is accounted for as he passes from grade to grade and from the grades to the high school. But not so with science; some misguided high-school, and even college, teachers have gone so far as to say that they would prefer to have their pupils come to them with no elementary work - a most preposterous position to assume. When the teachers from lowest to highest feel that all the good work they do will receive due recognition; when each understands that the true elementary work is as essential and fundamental as the more refined which is done farther along, then for the first time shall we be in the proper attitude of mind to develop a science course that will at once add strength to the curriculum and be a valuable contribution as a means to the development of the pupil. 
III. THE NATURE OF OBSERVATION.

One of the serious obstacles in the way of securing the best results in nature-study is that few teachers fully understand the nature and function of true observation. The primary reason for having introduced this study, as well as its ancestor, the objectlesson, into the school, was that. it offered a direct means of sensetraining. It is generally understood that sense-training is peculiarly necessary in nature-study, but it is not so clearly recognized that all education finally rests upon it.

Education depends upon observation. Whether it is in the domain of natural science, where, obviously, knowledge is gained by presentation of objects and phenomena to the senses, or in the field of history, where the lessons are to be interpreted and applied to life in its present condition, observation is of fundamental importance.

The most serious mistake made in dealing with the subject of observation is that of treating it as though it were wholly an affair of the senses. Educative observation depends not more upon the senses than it does upon the mental attitude of the observer. It is quite as much a concern of attention as it is of eyesight or hearing. It is the function of.observation to furnish data ; these data form the basis for determining relations - ultimately the mutual relations of form and function. The great fault to be avoided therefore, in planning and conducting work in observation, is that of insisting upon presentation of objects or parts of objects that make no appeal through either their function or their form. When this is done, it is inevitable that the interest must be spurred on by factitious means which never come from honest purpose and never lead directly to real knowledge. Through this mistake, chiefly, arise all the difficulties pertaining to the various forms of expression.

Observation is the mother of inference; given the former, the latter is inevitable. Nothing points more clearly to the distinct personality of each human being than the fact that no two persons will make exactly the same inference regarding an object which they observe in common. Each observes from a point of view that is slightly different from that occupied by the other, and his inferences vary accordingly. This may lead to endless contention; but discussion respecting the meaning of facts is always healthy until 
those engaged refuse to repeat their observations that their inferences may be corrected. The natural test for the extent and correctness of an observation lies in the expression which the individual is able to give respecting it. While it is not uncommon for one to say that he sees and knows more than he can express, it is doubtful if this is ever true. The technique of expression in all its forms is exceedingly simple. For instance, in expressing himself through a drawing, the pupil is required to do so by means of lines, straight and curved, which he can draw with little or no trouble. The real difficulty lies in putting the lines together at their proper angle, and in their right relation. But this does not belong to the technique of expression; the inability to represent by drawing must be referred, therefore, to the fact that the image is indistinct as a result of insufficient observation.

Again, in language, it is possible to describe things, most complex, by the use of words that are employed in common speech; yet it is not uncommon for the pupils to say that they can see more than they can tell, although their ability to talk may be beyond question.

In modeling, the clay is most plastic. It readily yields to treatment; but there are comparatively few who can bring it into a form which corresponds to the object observed. This is clearly not the fault of the material used, nor of the ability of the pupil to mold it; but the difficulty lies rather in an imperfect image that has been obtained through faulty or deficient observation.

The accuracy and the extent of an observation depend upon the purpose which controls the one who is making it. It is usually true that the desired knowledge concerning an object may be obtained through a partial examination, and the observation upon this point will be clear in proportion to the importance of the knowledge. All other knowledge of the object, which is absolutely necessary if we are to have an image of it clear enough to enable is fully to represent it by any means of expression, is weak and defective because the observation has not been intense.

Drawing, painting, modeling, etc., are difficult, therefore, because they require an accuracy and extent of observation which is not considered absolutely necessary by most people. For example, one may know, for all practical purposes of his life, the house in which he lives, and yet he may be utterly unable to represent that house 
in a drawing. That is, while he may know the proper number of windows in the front, he would fail, perhaps, in getting the due proportions of each window, and this would be because that particular observation had never been called out by any function that the house or window had performed for him. The window allowed light to come into the interior, and he learned to know it from this function, but he learned nothing more.

So in the study of a tree. The lumberman recognizes a tree by signs, most superficial, because his knowledge may end with knowing the kind of wood. The nurseryman by a glance merely at the fruit recognizes the different kinds of apple trees in his orchard. Both, however, might utterly fail in an attempt to draw the tree, because its function, so far as they are concerned, has not demanded that close and specific observation of form which must precede any drawing.

The fact seems to be that most people see just enough of an object to enable them to dodge it. Very much observation, so called, results in nothing more than a mere consciousness of the presence of the object. No image of educative value is formed. It will be a surprise to anyone to scrutinize closely the impressions received from an object, even after looking steadfastly at it for some time. He will find that he has been impressed chiefly by those characteristics and properties which indicate a particular function. Other characteristics and properties, no matter how important, lie indistinctly in the background of his consciousness, and it requires considerable effort, on returning to the observation, to bring them to their proper relation in the image.

Observation, therefore, does not become a vital part of the educational process because we wish to train the senses, but rather because we wish the senses to train the individual. They can fulfil their mission in furnishing data regarding the outside world only when the mind has been prepared through the impulse of a strong motive to receive them. The value of observation cannot be determined, primarily, by the character of the object presented, but, rather, by the attitude of mind which the pupil brings to it, or which the object before him can induce and control. Like all other educational problems, observation finally resolves itself into one of purpose or motive. There is no escape from this, and the only way to have it 
perform its proper function in nature-study is to be governed by the appeal which a generous presentation of nature makes to the child.

\section{IMAGING IN NATURE-STUDY.}

The direct purpose of observation is the development of an image. That it often falls short of this is a fact which will largely account for lack of interest in study, muddled thinking, and waste of time in education. Until an image of the thing desired is clearly formed in the mind, it is useless, and worse, to attempt to take the next step. Until this is done, in fact, there is no next step to be taken. To overemphasize the importance of external presentation, and to underemphasize the importance of the resulting mental product, is the mark of much poor teaching. This mistake is largely due to the intangible and indefinable nature of the image which in itself is the mystery of mysteries.

When an object or a physical phenomenon is presented to one or more of the senses, an effect is produced that in no conceivable manner can be said to resemble the cause. The phenomenon of vibration derived from a blow by a hammer striking some object may be traced along purely material channels, and its rate of movement is but a problem in mathematical physics. At a given point, however, its physical identity is lost, and in its stead there flashes out a mental phenomenon which remains. Assuming the integrity of the senses, each normal individual must bear witness to the constant correspondence between the physical presentation and the psychic result which is called an image. It is not properly an image, though, if there is associated with this word its ordinary meaning. An image is a likeness or a counterpart. The mental image is not a likeness, but a result which is remarkable in its unlikeness to the cause. In the process of living, during the conscious hours there is a continual effort, first, to interpret these psychic results - that is, to refer them to the proper material source; and, second, to organize them - that is, to discover by what relations they are associated. These operations are to the end that one may obtain his bearings and preserve his proper place in the scheme of creation. The process of education is the systematized attempt to economize this effort. It accomplishes its purpose only as it keeps unobstructed the pathway between the physical and psychic phenomena, and so far as it discovers methods of interpretation and 
organization that can be applied under the proper motive in dealing with psychic results or images.

Mental images, although bearing no resemblance to each other, may be considered as related when they can be referred to the same external source. The sound of the hammer striking the nail, the appearance of its falling through the air, the sinking of the nail into the wood, all give rise to images, that it is impossible to compare with each other; yet they are related, since they are referred to a common cause. When the psychic results of the sight giving color, and of the sight giving the effect of the blow upon the nail, and of the sound giving the nature of the substance, are interpreted as belonging to the same thing, the hammer, they become organized at once as the related parts of the image of the hammer, which has a certain form, weight, and substance. Psychic results may be produced from outside occurrences which follow in immediate sequence in time, or which may take place simultaneously; yet this timerelationship alone will not admit of their being organized into an image in the educative sense. As the hammer falls, a bird may fly across the field of vision; but the psychic result of the latter bears no educative relation to those derived from the hammer.

In nature-study, the landscape, embodying the entire field of observation, presents itself to the beginner as a great composite of confused parts; and to most people, perhaps, it always remains so. It should be the aim of instruction to assist the pupil to refer the separate and more or less confused mental impressions to the appropriate source, and, as this is done, to organize those referred to the same source into a clear and definite image. The landscape is revealed to the observer through its color, the initial interest being roused through the æsthetic sense. Everything, therefore, which involves color can be referred to a common external source, namely, light. All color-impressions, consequently, become organized in the mind, since they are related to a common cause. Whether it is the foliage of a tree or the decorative colors of a room, the questions arising in both are solved by this relation to the one thing - light. Still further, in plants many of the myriad varieties in form are nothing but inextricable confusion until their relationship to light is recognized; then the seeming confusion of forms becomes an orderly array. Even two structures so extreme in their unlikeness to each other as a leaf and the human eye become related, 
from the fact that each represents a concession of the organism to the same controlling cause found in light. A large number of landscape phenomena, therefore, may be grouped together, from which there will be formed an image of related parts representing the effects of light. Another group of phenomena will be referred in the same way to heat, another to moisture, another to soil, and so on. The channeling of the grass blade and the bladdery vesicles of submerged plants as isolated facts are of little importance. But when one is recognized as a dew-spout and the other as a swimbladder, and that both are an attempt to make friends with water, they become the organized parts of an image that is fundamental in the study of botany. Imaging thus begun opens the way to endless study. Simple enough in the outset to be clear to the child, the last step in scientific research is but the latest attempt of the trained mind to define more clearly the same image.

The chief reason why observation is slow and tedious is that sufficient aid in defining the image is not given through adequate expression. Expression is usually confined to one or two modes, whereas observation furnishes the data for a many-sided image which may need all the modes of expression to define it properly. People are continually wrestling with form, but they have almost no training in the development of form through the production of a model. They are continually called upon to distinguish colors, but expression through color has been practically unknown to most adults of the present time. Even in oral and written expression the pupils are enormously delayed by being compelled to deal with these modes in the beginning from the side of technique rather than from that of content. It seems to require endless time for teachers to learn that it is content which furnishes the motive to define an image, that must control technique in every form of expression. To attempt to teach technique beyond the demand of image-growth, or apart from it, is both to destroy the growth and defeat the real purpose of art-study. Even in most schools where the various modes of expression are employed the desultory character of the work growing out of and coupled with a corresponding desultory kind of observation tends to dissipate, rather than to conserve and strengthen, the pupil's power to image. If observation is of the highest educational character, the imagination is constantly called upon to arrange the different parts of the growing image in the 
proper order. Nature-study then becomes more than a simple amassing of facts; it involves also the organization into a rational and consistent whole. Science itself is nothing more. This kind of image-growth is educational because it is rationally continuous. No other kind of imaging is worth the trouble. The demand for details by an ever-incompleted image impels that research which always marks the true student of nature. 


\section{CHAPTER II.}

THE SCOPE OF NATURE-STUDY.

I. FIELD-WORK.

With that conception of nature-study which has already been set forth it follows that the children must lay the foundation for their knowledge by direct contact with nature under normal conditions. This end is to be attained by a variety of investigations, which for convenience may be classed under the head of field-work. It is not intended, here, to limit this to the mere collecting tours, but rather to expand the meaning so that it may include all the great aspects of life outside the schoolroom which may be conveniently studied. Field-work of this kind is usually done so irregularly, and with such a lack of well-conceived plan on the part of the teacher, that it often falls quite short of having its full educative value. The following principles, in accord with which outdoor work may be conducted, are offered as the basis of a plan that may be generally applied to the different aspects of field-work.

I. Each study should begin with a comprehensive survey of the landscape as a whole.- In thus treating the landscape, it should not be regarded as a great composite of confused facts, but as an organism of tremendous strength, having the relations of its parts balanced with the greatest delicacy.

Evidence of its strength, for example, may be witnessed in any garden or cultivated field. In the area of cultivation the foster-plant is brought into competition with wild ones that, in their own way, have made themselves possessors of the ground. It may be assumed that the conditions are generally favorable for the cultivated plant, or man would not have selected it for this particular spot. In addition to this, in most cases it requires the vigorous use of the best implements that the wit of man has yet devised to enable the plant to maintain itself against the onslaughts of the aborigines of the soil. There is not a cultivated plant in existence that would dare match itself, single-handed, in a race against the common garden purslain or pigweed on its own ground. As soon as a child 
is old enough to follow the growth of plants through a single season and to take some little part in their cultivation, he cannot but be impressed that this mighty support which nature gives to her own is something more than accident. In his realization of this fact is a stimulus that will drive him to examine, according to his skill, the leaf, the root, the stem, the seed, the soil, and all that has contributed to the victory of the one and the discomfiture or defeat of the other.

The delicacy of the balance that exists among the parts of the landscape is scarcely exceeded by the sensitiveness of the poise maintained by the organs of the living body. The slightest change anywhere is sufficient to destroy the balance abruptly and cause a readjustment of all the adjacent parts. The drying out of a marsin is marked year by year with a gradual reorganization of the flora and fauna. The falling of a tree in the midst of a forest allows a few shafts of light to fall unhindered upon the ground. Forthwith the shade-loving plants are driven from the spot, and grass sets in and works its way in all directions, literally, according to its light. The gradually changing course of a stream is continually reorganizing the life in the valley. The advent of a stray plant or seed may light the torch of conquest. Driven almost to desperation by the chance introduction of the Russian thistle, the farmers of the Northwest have besought government aid as they would against an army with banners.

Such a presentation of the landscape, by its simplicity and breadth, will not only attract the attention and enlist the interest of the children for the time being, but it will also place them at once in line with the best materials and methods of science.

2. In proceeding from the landscape to its details, the study should be directed to its related parts, not merely to unrelated fragments. From the whole to the parts in this instance does not mean from the whole to the pieces.-Almost any stretch of landscape will present some evidences of an underlying unity. Within the general scope, certain aspects or phases in its appearance will indicate minor related unities. Thus, in general, a landscape may include a valley or a stretch of prairie, each having a certain completeness. Within this there will be slopes, or marshes, or ridges, or lakes; and each of these aspects will be found to stand as secondary centers of organization for the plants and animals; and, still further, each 
minor center may be resolved yet into others, which have an organizing influence within the whole. The rational study of a landscape involves nothing but the study of the relations that exist among its parts.

The course of a stream is the dominating organizing influence in a valley. But each slope, especially if the stream lies east and west, will have an organizing individuality of its own. The writer recalls two such slopes which supported the two species of a genus of plants. Each species, however, was confined entirely to its own particular hillside, though the valley was not more than a quarter of a mile in width.

Each slope will present in itself different centers of organization. Even the casual observation of children will show that it is something more than accident that segregates the plants with the fine capillary roots on the sandy crest, and that it is more than coincidence that groups the thicker-fascicled roots in the alluvial bottoms.

Even a single living tree becomes an interesting center for study. It is beset by many things that without it could not possibly exist. The green algæ on one side and not on the other speak of the contrasts of heat which it affords. The moss clustering at its base, and ascending the stem in a thinner layer, accurately measures the area of moisture furnished by its capillary bark; while the papery lichens take undisputed possession of the dryer areas above. Its dried and riven bark furnishes protection for crowds of insects that find shelter in the crevices, and these in their turn become the chief attraction for a vigilant host of birds. Even when dead and prostrate it is a center of no less activity. Beset by a new race of animals and plants, it remains a determining influence upon a considerable community until the last vestige is returned to the original elements. Here again a broad presentation brings the pupil at once face to face with nature at work. He acquires some notion of the dynamism in creation, which is the beginning of wisdom.

3. The landscape as a composite whole presents several series of aspects, each of which includes a well-defined succession of events. - These may be described as:

a) The transitory and somewhat irregular changes; as, for example, those caused by the movement of a cloud over the sun, the passing of a storm, the work of a flood, etc. 
b) The seasonal: those which accompany the changes of temperature and other modifying climatic influences.

The observations under this division should take several directions :

(I) Toward a determination of the amount of sunshine. With the younger pupils, the variation in proportion to the day's length and to the amount of cloudiness can be understood. With older pupils, the relative values of sunshine, also, determined by the varying slant, can be calculated from measurements easily made.

(2) Toward a determination of the temperature of the air, of the soil at different depths, and of bodies of water.

(3) Toward a determination of the amount of moisture in the soil at different depths and in the air.

(4) Toward a determination of the amount of rainfall, and the distribution of rainy days through the year.

(5) Toward a determination of the amount of water, ash, and other constituents in plants at different periods of growth.

(6) Toward a study of all the habits of plants and animals germination, growth, maturity, nesting, feeding, migration, etc.that are associated with the season and conditioned by it. The presentation need not be in accord with any fixed order; the topics indicate merely the general observations that should be made.

c) Those operations resting upon profound causes, which; gradual and subtle, effect radical and permanent changes. Thus the slow drainage of a marsh (it may be for the purpose of agriculture), the denudation of the country of its timber, the encroachment of the water upon the shore or coast line, the shifting of the sand-ridges by the wind, the breaking of the shelving rocks in the cliff, are all changes which almost imperceptibly, but profoundly, affect the balance of parts in the landscape. These changes differ from those first named in being more gradual, and from those mentioned second, in being irregular. Whatever there may be of recurrence is at intervals that seem to be variable.

4. The study of landscape details, therefore, means the following of each minor unity, through each of these series of aspects as the changes occur, with due regard to the relations of the various aspects to each other.-For example, a tree presents certain phases of life which are due to the daily and hourly shifting influences of sun and shower, of light and darkness, etc.; these phases are 
marked mainly by the constant play of shade, tint, and color. Still further, other phases appear that correspond with the month and season; these show themselves in bud, leaf, flower, and fruit. And, finally, there are those phases which present themselves through the accumulation of years that are found in the tree's maturity, its decline, its death, its decay, and in the distribution of the elements of which it is composed. A true study of the tree will consist, therefore, of the thoughtful consideration of all the different phases of life which it presents, with due regard to their relations to each other and taken in connection with the underlying causes. The results of such study will always appear as a rational and coherent story, whether it is told by tongue, brush, spatula, or pen; but the description can be even approximately complete only when all are used. Every feature of the landscape, whether it be a plant, an animal, or a rock, must be studied in the same general way.

5. The different serics of aspects presented by the landscape make their appeal according to a well-defined order which is determined by the age and experience of the pupils.-The series of fleeting aspects possessing a lesser, though subtle, significance is strikingly beautiful, and they are generally most attractive to children. The appeal is made chiefly to the æsthetic sense; and, as these phases manifest themselves largely through changes in shade and color, the mode of expression must correspond.

Those aspects, which are included in the regularly recurring events of the season, have a deeper significance, none the less beautiful; but, in their relation to man, they appeal strongly to his notions of utility. Through this appeal, which reaches the mind gradually as it matures, they call forth from the human being those inventions, arts, devices, measurements, and calculations which have enabled man to utilize the forces of nature.

The series of aspects, including those gradual changes that can be timed, perhaps only by ages, enlist the profoundest interests of the mind. No comprehension, even approximately adequate, is possible without the aid of a great perspective of experience which has been developed through an intelligent contact with nature. The real significance of these larger aspects of creation can never fully appear. They make the appeal only as the mind ripens, and they become intelligible only as it acquires the disposition and the power to arrange, in accordance with the rules of philosophy, the facts that have been gathered and treasured by sense. 
In a study of a landscape, therefore, the teacher and pupil should seek for the dominant influence which organizes it into a great unity. For example, in the area in and about Chicago the center of influence at present is the lake, while one a little more remote and far-reaching is the glacier. Everywhere the country presents the character given to it by the lake, present and past. The sand, the pebbles, the small lakes and pools all testify to its work. But within this area are minor features which themselves operate as centers of influence. The trees, for instance, speak of the sandridges everywhere; while the rushes, reeds, flags, sedges, and coarse grasses speak of the more or less submerged lowlands.

The innumerable colonies of animals and plants which infest these minor centers tell of still further contrasted conditions, which differ from each other in slope or soil or sunshine, but mainly in water supply. The chance excavations in road-making or for buildings reveal something as to what the conditions have been in the past. The rapidly occurring changes which accompany the settlement of the country - the displacement of the fish, the tadpole and frog, the mussel and snail, the heron, rail, snipe, and bittern, by the earthworm, the toad, the snake, and the lark; the substitution of the fine meadow grass for the water lily, the bulrushes, the flags, the cattails, and the sedges - all give a glimpse of what the future may be. To decipher the story of the past, so to interpret the present that we may plan for the future - this is the fundamental purpose of all field-study.

\section{NATURE-STUDY AND MAN IN THE LANDSCAPE.}

One of the most important lessons of field-study is to show how man by slow and progressive stages avails himself of the various natural features of a given area. The home life, the industries, the transportation of products, the location of towns and cities, are in the immediate control of the natural features. Among these the most important is water supply, and this in turn is closely related to the nature of the rocks. A limestone region usually abounds in springs. The water, filtered and cool, is a prime necessity in the human life. Hence it is that in such a region the location of the home, the fundamental unit of our social and political system, is determined largely by this single physical feature. The pupils can easily canvass the area within reach of observation and 
note how uniformly this fact prevails. But the springs, still further, do much to determine the topography of a region. The general land-slope determines the direction of the water-flow, but the water and the nature of the rocks determine the channels and the character of the sloping sides of the valley. These, in turn, fix the accessibility and the immediate surroundings of the home which so powerfully react upon the life and character of the occupants. If the site of the home is unfavorable from the rsthetic or artistic standpoint; if it is beset by features which render it difficult of access; or if in any way the physical features make the labor for a livelihood so onerous and taxing as to leave little time for the rest and leisure so necessary for reflection, reading, and study, the character of the people who occupy such homes will be distinctly affected thereby.

The location of the roadways, too, are closely connected with the physical features. They follow, as far as practicable, the ravines and valleys that have been caused by the streams because of the easier grade. It reduces the cost of transportation to recognize this particular point. When it is necessary for the roads to ascend the hill, it is interesting to note how with increasing intelligence the grades are carefully surveyed and improved. In locating the railroads, too, the same features are observed; the easiest grades are along the streams.

The natural lines of transportation determine also the location of the villages, towns, and cities. The convergence of even but two country roads to a common point is often enough to establish a store, with perhaps a post-office and a cluster of houses. The two roadways bring to this point the merchandise or products of two or more different sections, and the opportunity for trade is created. The amount of barter and sale depends upon the soil, the natural products, and the extent and character of the thoroughfares. If the latter are two rivers, for example, of navigable size, a city is the inevitable result. These are enormously reinforced, but never quite replaced, by railroads that give speed to the movement of goods, but always at increased expense. The streams of a country are closely associated with the industrial history. They furnish the earliest and cheapest power for various kinds of mills. The course of almost any stream will show a number of generations of these which have come and gone keeping pace with the settlement 
of the country. First, the old overshot wheel, cumbersome and wasteful of water, then the turbine, and finally the steam-engine supplanting both - each serving its day and purpose; each represents a given horizon of ability that man has reached in availing himself of the natural features of his environment.

The location of the timber reserves, of the quarries, and of the mines bears a direct relation to the value of the soil for the purpose of cultivation, and to the natural transportation facilities. The houses, too, show an interesting evolution. The earlier ones were of woodlog cabins - or sod dugouts. These are often followed with stone buildings, when quarries of good building-stone are a part of the country's features. These are still further succeeded by either wooden ones of finer worked lumber, or by cut stone, or it may be by imported brick and tile. This study tends to bring out the fact that education and training do not, as often supposed, enable man to live at variance with nature, or in a measure independent, or even at war with her. They simply show how man learns to avail himself more widely of the benefits that nature is ready to bestow upon those who are willing to consider themselves a part of the great whole. This is the fundamental motive for nature-study. It can be brought to the experience of children of the earliest teachable age; and, once fixed, no artificial stimulus to observation will ever after be needed. The study of nature then becomes for the pupil a personal matter. Its problems are personal ones that make their appeal directly to him. There is an abysmal difference between learning about nature and learning from nature. Both methods of study may have outwardly the true scientific form; but it is the latter only that is really educative. In the former process the student finds her inert, spiritless, and dumb. In the latter she becomes active and eloquent, and almost conscious in her meeting at every point the gradually awakening needs of man.

\section{THE FARM.}

As a smaller or minor unit in the general landscape the farm may be considered as practically a natural division. When the topography varies at all, the farm boundaries will usually follow certain natural lines. For example, it is difficult for a man to farm if his land lies on opposite sides of a deep ravine or sharply divided ridge. The effort is made, then, in buying and selling, to recognize the 
fact, and so to arrange the lines that each farmer may get land that can be worked to the best advantage. Farmers who do not recognize these general facts soon find themselves in possession of undesirable areas, and consequently they suffer actual financial loss and physical discomfort from their failure to observe the character of the natural features.

The different soils and locations are always considered in the choice of crops. The lower lands are chiefly for grass; the higher for grain; the warmer southern slopes for corn and early pasture; the cooler northern hillsides for wheat and oats; the alluvial bottoms for gardens and vegetables, and the well-drained uplands for orchards and fruits. This distribution does not represent the arbitrary choice of man, but rather his implicit observance of the general facts of temperature, moisture, and soil. In short, all the rural occupations of agriculture, horticulture, and grazing should be determined upon beforehand by a scientific investigation of natural conditions. It would be preposterous for a man to erect an elaborate and expensive gold-mining plant on a spot that had not been thoroughly prospected. But many thousands of dollars are spent and endless disappointment results from a failure on the part of farmers to "prospect" similarly their farms before they begin their work. These financial losses, and the infinite social and physical discomforts of country life, will not be relieved until people are recreated by that rational study of nature which it is the function of nature-study in the schools to stimulate and direct.

It is important, too, to study the relation of the farm as a unit to all other sources which minister to the comfort and happiness of people. The country roads which radiate in different directions from it as a center are but the beginnings of lines that may connect it with the ends of the earth. Along these simple paths of transportation may begin the flow of aid, comfort, and blessings to people of every degree of need and in every station in life. This should be made in the lives of the children a personal matter. Upon their personal effort, their personal industry, honesty, honor, and integrity, depends the welfare of those more or less distant people to whom they are thus related. The fact that their productions are to be consumed by people in a remote quarter of the earth, savage or civilized, instead of by neighbors on an adjoining farm, lessens not one whit the obligation that such productions shall be prepared as 
honestly as nature can grow them. A pound should mean precisely a pound, and the contents of the package should correspond exactly with the claims of the label. The pupils should be taught that there are practically no limits to which the distinctively fine products and the distinctively honest preparations may not become known and honored. Inward, toward themselves, over the same routes flow the contributions demanded in their daily lives; and they learn in a different way to appreciate those qualities of character in others which others are glad to recognize in them. Herein lies the root of finance, and here is the basis of social and political structure. The financial condition of the farmer depends upon the ratio of his sales to what he buys. His wheat, corn, cattle, and minerals he transmutes to gold; if this be not used in part for those imported products which he naturally requires; if it be hoarded and put out at usury, instead of being devoted to means of perpetual intellectual attainment; if through it he become not a source of greater general influence, then the very last and highest lesson that nature has to teach remains unlearned, and ultimate disaster, if not to lim then to his children, is the inevitable result. Here again, in this approach to nature, we find the motive for the study. It is not remote; it is immediate. It is not vague; it is definite. It is not something which can be deferred; it is that from which the stimulus to the study must proceed.

\section{THE GARDEN.}

A most common and useful adjunct of the home is the garden. It offers an approach to nature that is fascinating both to old and young. The fresh and odorous earth; its swarm of worms, grubs, and insects; the birds rejoicing in the bountiful food supply; the spontaneity of the plants, incarnating as they grow the mysterious force of the sunshine; the appetite whetted by the gradual appearance of the vegetables that bring release from the monotonous and heavy menu of winter; the flowers that, in patches, rows, and clumps, give changing color to the whole - all these combine to draw man irresistibly from the usual daily routine and to place him once more under the benign influence of primeval nature. The children are charmed with the opportunity to do such work; they are not fretted by the feeling that it "does not seem to be like school," which is always the source of more or less worry to the older ones, to their teachers, and to the parents. 
The many vacant and desolate-looking school-yards still to be seen in both country and city; the door-yards of thousands of houses that almost cry out against the indignities of rubbish that are thrust upon them by careless and ignorant people of vulgar tastes, all testify how far away we still are from knowing how to utilize effectively a most potent means in education.

There are few problems in the plant world that are not presented in the garden in a form fit for study. It is true, too, that animal life is but little, if any, less well represented. It is a perfect laboratory in which to study the subjects of temperature, light, moisture, soil, and air that are the fundamental conditions of growth.

The chief reason why the school garden often falls short of the hopes of those who plan for it is that its projectors usually greatly underestimate the attention and labor which it should receive. Gardening is one of the highest arts, and there can be no more serious mistake than to suppose it is only necessary to plant the seeds and let them grow. Bacon said long ago that men come to build stately sooner than to garden finely.

It should be remembered in the outset that, in several senses, a garden represents a war with nature, as the latter term is usually understood. In the first place, it is commonly made up of plants that have been drawn from remote parts of the earth, often from places having diverse climatic conditions. These are all expected to grow within a limited area, for which naturally, they are not specially suited, and their "personal" objections are supposed to be overcome chiefly by artificial means and by processes known as cultivation and forcing. Cultivated plants can never be made to forget the ancient haunts of their ancestors. The one, therefore, that flourished best in primeval times in marshy soil will never feel quite at home in a dry, loamy garden alongside of a plant that has been enticed away from a sandy ridge. Nor will a plant which has been kidnapped from a warmer climate take kindly to a yokefellow that has spent countless ages in learning how to outwit the north wind.

In the second place, almost every cultivated plant may be regarded as either a freak or a genius; usually it exhibits all the eccentricities of both types. Man, in looking selfishly after his own ends, in many instances has seriously interfered with the ancient and prosaic process of seed-production, which comprises the whole 
of a plant's ambition in the wild state. Even where the want of the gardener and the need of the plant meet in the same thing, as in the seed, in some underground forms, and in many flowers, these parts are forced by the tricks of cultivation to a point in size and number that the plants could not sustain for a single season if they were left to battle alone with the elements and their natural enemies. Thus the potato, as well as the turnip, parsnip, and other roots; the cabbage, kale, kohlrabi, and other leaves and stems; the peas, beans, and other seeds, in their present marketable form, represent the ambition of the gardener rather than the needs of the plants themselves. The distortion and exaggeration of the normal form found in the majority of cultivated plants represent with fair directness the modification of the natural conditions under which these plants are produced. If members of the vegetable world were endowed with reflective powers, they would certainly view some of the results obtained by the gardener with alarm; as, for example, the production of the "seedless fruit" and the double flower, in which the original purpose of this particular part is entirely defeated.

Again, it should be remembered that cultivated plants are not only herded together without much regard for their natural affinities, but they are set down in a place which in most cases was pre-empted ages ago by other plants that have learned thoroughly. how to take care of themselves on that particular spot. It has been part of the business of these plants to kill off without mercy all members of any weakling tribe that might appear among them. The enormous strength with which these "natives" literally hold their ground is evidenced by the fact that the gardener's favorites must be aided and protected by the active and vigilant use of the best instruments yet devised for the extermination of weeds in order to carry the cultivated crop to a successful issue. There is no more striking illustration than this of the trouble one may expect, if he interferes with one of nature's established ways.

In designing a garden in connection with an ordinary school, therefore, three things should be observed: (I) select plants which do not represent a wide diversity of habit, unless the garden will lend itself to a variety of conditions as to water, sunshine, and soil ; (2) select plants which represent fairly well-established stages of cultivation; that is, avoid the so-called novelties, unless there is 
ample provision for unusual attention; (3) allow plenty of time for systematic care; odds and ends of time will not do; the weeds do not grow by fits and starts.

For the æsthetic effects of the garden most people will depend upon the flowers and ornamental foliage plants. Several arrangements may be suggested which will commend themselves according to the taste and opportunities of different individuals. The following is a description of the garden planned and cared for by the pupils of the University Elementary School:

The garden occupied a plot of ground lying on the south side of the school building, 55 meters long east and west, and 30.5 meters wide north and south. The south side and the ends were inclosed by a wire netting 6 feet high, and the north side was bounded by the schoolhouse.

The main cultivated portion was a strip near the south side 48 meters long and 12 meters wide. In the middle of the strip a circular bed 12 meters in diameter was devoted to flowers, oneeighth of the area being assigned to each grade. A bed in each corner, 6 meters square, was sown with spring grains. The four remaining plots on either side of the circular area, each about 6 meters square, was assigned to the grades as marked, and they were planted with vegetables.

Near the building there were nine beds, in which about one thousand tulip bulbs were planted in the fall. After these had finished blooming, their places were given to plants that bloom later in the season.

On the walls of the building, between the windows, preparations were made for planting a great variety of rapidly growing vines, which, it was believed, would somewhat soften the glare of the summer's sun upon the treeless grounds.

At the inner end of each bed, in the circular plot reserved for flowers, there was planted a castor bean; at a suitable distance from this, moving outward, there was planted a calladium; next was a ring of salvias; then corntlowers, verbenas, and a border of phlox, or sweet alyssum. By this selection and distribution the bed had the features of ornamental foliage and flowers, which was made possible by its large size. The flowering began rather early and, by the choice of plants, continued until frost. The order 
decided upon gave each different kind of plant a fair opportunity for growth.

The four adjacent areas on either side of the flower-bed-one for each grade - were devoted to plants selected for their economic value. Such plants were selected as would be useful in preparing the children's luncheons the next year. To this end each plot, 20 feet square, was devoted to one or two kinds of plants, and the grade caring for it was responsible to the entire school for the result. The plants chosen were beans, peas, potatoes, cabbage, carrots, parsnips, beets, tomatoes, turnips, onions, peppers, cucumbers (for pickles), and corn. Radishes and lettuce were sown in certain spots not available for other plants.

It was proposed to show, for example, the great debt of mankind to the Cruciferae. There is no part of the plant body that has not been developed in different members of this useful family for the food of nan; thus, in the turnip and radish, the root; in the cabbage, the leaves. The Solanaceae were represented by the tomato, potato, and pepper, the innocuous relatives of the poisonous nightshade. The parsnip and carrot represented the Umbelliferae, and beets strove for the ascendancy with their wild and vigorous relative, the pigweed of the goosefoot family, or Chenopodiaceae. The peas and beans are the favorites chosen from the Leguminosae-an interesting family of plants, both useful and ornamental.

The four areas at the opposite ends of the garden were devoted to various members of the grass family - maize, wheat, oats, rye, barley, broom-corn, and sorghum; and a small strip was sown with flax. Later in the season some space was found for buckwheat, the most useful member belonging to that family of gutter snipes, the smartweeds. The same aspects for study were presented by the plants cultivated for their flowers.

In connection with this part of garden-work there are three interesting lines of study: (I) the original habits of the plant in its wild state, and its near relatives that now may be found growing wild; (2) the steps in cultivation and the conditions provided which have developed the cultivated form; (3) the nature, constitution, relative value, and distribution of the food-product thus obtained.

Another point of view from which the garden as a whole was studied is that of the actual problems which the different plants 
must solve in the process of growth during different periods of the season. These problems are alike to all the plants cultivated in the garden, though differing somewhat in degree of importance. They arise mainly from the plant's efforts to establish helpful relations (I) with sunshine, meaning both light and heat; (2) with the soil for support and as a water reservoir, as well as for the sake of small quantities of minerals; and (3) with the atmosphere as a reservoir of oxygen and carbon dioxide as a food-supply.

The clew to a solution of the problems falling under (I) and (3) are found chiefly in a study of the leaves, including their mode of attachment, position, relative size, shape, margin, arrangement, structure, and movements. The problems involved in (2) are to be worked out through careful observation of the root, beginning when it leaves the sprouting seed.

Certain movements of the plants were shown by the various kinds of climbers that were trained up the walls of the schoolhouse. . The amount of work done by the plants was approximately calculated from data gathered from growing plants under special conditions. Thus, the amount of water discharged through the leaves was found by growing a plant in a wide-mouthed bottle closed about the stem so as to prevent evaporation. By weighing at intervals, placing the plant now in the sunshine, now in the shade, the loss noted will be from transpiration, and the quantity of water can be measured out so that the pupils may see it. Plants may be weighed fresh, and afterwards dried and weighed again, then burned, thus giving an idea of the water and of the dry solid, and mineral matter built up during any given period of its development.

Again, the resources upon which the plant must draw for materials were investigated through a study of the soil, rainfall, temperature, slant and distribution of the sunshine. The gist of the whole study under this head is (I) to see how the plants suit their problems to the seasons: germination to the cool, moist April and May; the rapid development of the leaf and flower to the long, bright, hot days of June and July; and the filling up of the seed to the early autumn; and (2) to observe how they manage to resist the encroachments of each other and to use each other, as they all together take possession practically of the whole earth. 
V. THE DWELLING.

Something has been said already about the relation of the home to the general features of the landscape. People as yet by no means fully realize how directly its great aspects affect them. This does not refer to the momentary effect upon the emotions, but to the power that such influences have upon the development of character. The constant presence of a great mountain range, studded with its cloud-capped peaks; or of a sweep of water whose surface, whether smooth or turbulent, is a constant reminder of the primitive forces of nature; or of the majesty of a river that rolls its way from hill to hill through a valley; or of a stretch of prairie whose vastness seems to lift and expand the arch of the sky into an almost limitless dome - the constant presence of any of these great elemental facts of nature insensibly impresses itself, especially in the early years of childhood and youth. In later years we become conscious that these raw materials, by the mysterious chemistry of life, have been transmuted into the strength, the refinement, and the subtleties of human character.

Realizing these facts, the outlook of a home becomes an important consideration. Farms are usually purchased with an eye chiefly to fertility of the soil, but no less attention should be given to possibilities of outlook for the dwelling. The site of a home does something to determine whether its occupants will be honest or dishonest; the way it faces will in some degree determine whether the family will be happy or morose. These facts are not the products of the imagination belonging to the domain of poetry; they rest largely upon chemistry and physics, and are the legitimate considerations of science. In its construction, from the arrangement of its rooms and windows so as to secure the maximum amount of sunshine, to the means employed for the disposal of garbage, everything should rest upon scientific principles. The character of the soil and subsoil determines its stability upon the foundation, and it also affects the drainage. In latitudes having long winters the questions of heating and ventilation are of paramount importance. To solve these problems, properly, requires a fairly liberal education in physics and chemistry. Most of the teaching and most of the text-books in these subjects, however, are still as hopelessly dull and remote as though no such necessity existed. Modern construction involves plumbing, gasfitting, and 
electric wiring, all of which rest upon the very latest results obtained by experts in physical and sanitary science. Many houses may be so located that the water supply, delivered from a spring having a higher level, may be piped to all parts of the dwelling where it is needed. These and other conveniences, which soon become necessities, might have a place in many homes, were the instruction in the schools to take them into due account. The actual personal investigation into one's own home, with a view to understanding its relations to himself, is certainly as legitimate as it is for him to spend his time in the study of the red man's wigwam or the igloo of the Esquimos.

The study of the materials that enter into the construction of the dwelling opens endless opportunities for observations. The stones can be traced to the quarries and to the rock strata from which they were obtained, the bricks to the "yards" and to the sand and clay pits furnishing the raw materials. The processes of manufacture are easily understood, and may be duplicated by the pupils themselves. The use of wood and iron in the building, the strength of materials, and the means of testing the same open to the pupils the usefulness of mechanics which is one of the most interesting branches of physical science to children.

The lack of knowledge and appreciation of nature is not more apparent on the side of the mechanical and sanitary aspects of the average home than it is on the artistic side. Thousands of homes and schoolhouses too, that present an appearance of neglect and desolation might be made beautiful by a little thoughtfulness and care in the planting of trees and shrubbery. Landscape architecture is, indeed, one of the most refined sciences, drawing, as it does, directly from the fields of both technical science and art. It is especially close to the interests of children, because of the direct appeal which it makes to their resthetic nature. But the neglected door-yards everywhere testify to the insensibility of the general public to the importance of this factor in the education of the children.

The dreariness of the exterior, as a matter of course, usually finds its counterpart inside the house. The waste of Sahara is not more lonesome than a house whose furnishing and decorations bear no relation to the lives of the occupants; that do not grow out of and bear the impress of the thought of those who live with 
them. Instead of really contributing to the joy and movement of home life, such decorations introduce a stiffness that always exists between strangers. The parlor and "best rooms" become places to be shunned, not enjoyed, and the real available portion of the house for living purposes becomes narrowed down to those regions where the work is actually done.

This opens up at once the true function of the domestic arts. Instruction in textiles, manual training, modeling, drawing, and painting should at this point find easy entrance into the lives and affections of the pupil, and nature-study properly presented should furnish an inexhaustible supply of material and an endless variety in design. It is useless to try to teach the relation of nature-study to art until the pupils feel a need for the art-until they see a place for it and begin to picture in their imagination what it can do. The study of art usually begins in a gallery which is but a warehouse and most people grow old and die without once realizing that it can exist anywhere else.

Homes that are made more livable through a greater sanity of arrangement and decoration would react powerfully upon the social relations. In many otherwise good communities the people are not social because they dread each other's parlors; whereas, if their rooms expressed something of the actual joy that the people get out of living, they would add immensely to the pleasures of social intercourse.

This phase of home life offers one of the easiest and most obvious points of departure for the instruction of our pupils, but it is one of the last to be discovered. If teachers were to devote as much time to such instruction, were to bring to it the same enthusiasm, the same use of pictures and books which they now bring to the study of the houses of savages and of primitive men of other days, their own homes and home life and the general social condition would be almost revolutionized in a generation.

\section{THE CITY.}

The most that has been said and written about nature-study has been done with direct reference to the country. The city, however, is no less a natural object than a tree or a fox. It belongs to the earth; it is as inseparable from it as a mountain range or a river, and it should be studied in precisely the same way. Chicago is 
no less a natural feature than Lake Michigan. The waves that roll up on the sandy beach are not more natural than the stream of life that rolls up and down the streets of the great city. As in the case of the country, the study should begin with field-work. The location of the city, as a natural feature, in the landscape, is as truly a theme for nature-study as the clouds that float overhead. The widest possible conceptions of which the children are capable should be developed first by observation of fundamental conditions. The great congregation of people upon one spot has a general meaning that appears at once on the surface. Just as the single dwelling is built with due regard to the country highway and the village with regard to the "crossroads," so the city bears an obvious relation to the great highways of commerce. These all center in its markets, and from them again traffic radiates to the country. The location of the earliest dwellings and business houses will be found to bear some relationship to the primitive natural features which lend themselves to economy of construction, to sanitary conditions, or to business advantages. From these initial points as centers the buildings creep outward along the natural lines of least resistance. The surrounding farms gradually change their general agricultural character to more special forms of gardening, the raising of small fruits and other products to meet the immediate demand of the city. In their turn, these areas become suburban, and are finally absorbed, becoming secondary business districts that accommodate the part of the population that is now too remote from the principal centers. The transportation facilities follow the population and play an important part in differentiating the residence sections from those devoted to business. As the town or city is favored with natural means of communication with other points, it reacts upon the surrounding country to an indefinite distance, stimulating productive energy. With the increase in production of raw materials, the city is driven to take advantage of whatever natural features there may be which favor manufacturing, thereby diminishing labor and expense in shipping and acquiring additional profits from sales.

From the side of nature-study, the facts to be emphasized here are those which show the close adherence of man in his city building to natural conditions. Just as the root of a tree seeks this way and that for the moisture and the best soil, so the growing city seeks and finds its nourishment in equally elemental features. A 
city so developed possesses the stability and the majesty of a mountain, and it bears no more relation to the sporadic growth of the illy considered "boom town" than the towering oak does to the made-up plant with paper leaves. The result of such study will be to unite the interests of the city and country in the minds of the pupils, not to separate them. The life of each will become less strange to the other, and every step taken will tend to develop and strengthen the bonds of sympathy necessary to a happy social life and to strong political existence.

\section{NATURE-STUDY AND HISTORY.}

In adapting the general plan of nature-study here suggested to a particular region, it is evident that it will involve many interesting facts in history. Our country is so young that its history is comparatively simple, and the relationship of man to primitive natural features may be easily traced from the earliest settlements.

A study of boundary lines will usually show how the present farms have been derived from those of larger areas which were secured by original government grants. This will be true also of the township and county lines. The history of all boundaries, political or otherwise, will show the influence of topography and natural products, in which ravines and ridges play a conspicuous part.

From the first generation that devoted itself to pioneering and the rudest agriculture almost everywhere, there have issued those specialized occupations that mark at each step a close acquaintance with nature. Each occupation has drawn to it men of a peculiar type of mind and of a particular social grade from the Old World, and each has exerted a unique influence upon the education of the young. The undisturbed quiet of a strictly agricultural and grazing region has produced a distinctly different kind of man from the one developed in a mining or a manufacturing district. An area not easily accessible by natural lines of communication lacks the alertness and progressiveness in its people usually found in communities having freer communication with social and industrial centers of a somewhat different order. The effect of the occupation upon the intelligence of the workmen is simple and direct. It would be unreasonable to expect the same mental and moral character in a man who delves day after day in the gloom of the mines, performing an endless task, every day's part being 
like that of every other day, that we should expect to find in the man who under better physical conditions performs work which at every moment exacts his individual and personal initiative. The great differences which are easily recognized do not arise because the one kind of labor is so much harder than the other; for both may make about the same drafts upon the sum total of human strength. They depend much more upon quality - upon the kind of reaction that they stimulate in the worker. Herein is the real reason for the long struggle for shorter hours in the working-day; it is not so much that the muscles may be relaxed, as it is that the mind may be released from the monotonous alternatives of the pick and shovel, and the rhythmic bang of steam-driven tools. The short working-day will accomplish its true purpose only when the hours now largely spent in idleness shall be filled with some stimulating purpose that turns the energies of the individual upon some personal problem relating to the public good.

Mingling with the influences of the present surroundings are the traditions that in many instances go back to some remote spot in the Old World. The result is a general disturbance of ideals and a modification of methods that serve to add to the confusion which a great diversity of new conditions would of itself naturally induce. Add to this the theory of self-government, only imperfectly understood, but which by its very terms must mean the extreme reverse of what a large part of the people have been accustomed to, and there is no need to seek farther for the causes of social and political turbulence. The mystery concerning the origin of political parties no longer remains; the only wonder is that there are not more of them than already exist. The shifting of political boundaries in our country's history following, now one great natural feature, now another, is a very simple story that need not be detailed in this connection. The pupils should be taught to study the great drama, not as a spectator reviews the panorama of the stage, but as active participants. For most people history is an affair of the books; for our pupils it should be a matter of present concern and of personal experience. It is only as they really become intelligent as to man's place in nature that the theory of self-government can be appreciated or fully understood. It is from such wisdom that the proper machinery of government must be devised, so that the mutual and natural relations between the governed and their repre- 
sentatives may be preserved. Civics is as essentially a subject of natural history as are the instincts of the brute creation or the habits of climbing plants. When we learn how to draw its lessons from the story of man's efforts to adapt himself to ever changing conditions, it will be possible to frame a machinery of government that will be flexible enough to meet his growing needs, and still have all the stability of nature's laws. 


\section{CHAPTER III.}

\section{THE STUDY OF INDIVIDUALS VERSUS THAT OF TYPES.}

ONE of the most important reasons for the remarkable hold which the stories of history and biography take upon the minds of children, and of older students, too, is the fact that they contain a dramatic element which fires the imagination. The characters portrayed in history are in action; they are doing something which always involves their relations to others, and the part they play is easily recognized as being essential in the general movement. The events themselves become the embodiment of action. One thing follows another in an order that stirs the emotions, appeals to the reason, and irresistibly fastens the entire attention. The treatment also of the subject-matter has been essentially different. In the teaching of history, there is a careful arrangement of details in a proper perspective. The great actors stand well in the foreground as chief centers of interest. The influence of a people, often covering the entire life of a nation, is summed up as a single event in the great historic succession.

The plan followed by most teachers of nature-study has been the reverse. Believing it to be largely an affair of the senses, the pupil at the outset is completely immersed in details so numerous and minute that it is beyond the power of his reason and imagination to reduce them to order. It is as though the teacher of history should begin the study of a great military campaign by a critical study of all the different kinds of buttons on the uniforms of the soldiers. The imagination is a fact and a factor in human education which must be taken into account, regardless of the kind of subject-matter presented. If the presentation for any reason fails to reach and rouse the imagination, no educative result can come from it, though the appeal may have been made to every sense in the body. Many teachers, realizing the lack of this element in nature-study, have sought to supply it by treating all individuals under the guise of human beings. There is nothing in nature, from a raindrop to an oyster, that has not been personified in the hope that this personal relationship to the pupils may be brought out a 
little stronger. The general effect of this plan reminds one of the grotesqueness of the hand-organ monkey that is dressed up in a red coat and a cocked hat. His ill-fitting garments certainly add nothing to his character as a monkey, and they fail to give him anything of the bearing and dignity of a man.

An attempt has been made in the foregoing pages to show how the pupil may become properly conscious of the sweep and movement of nature. The events of the year keeping step with the seasons, if properly presented, form the natural setting and background for all the minor details. The latter must be studied as to the part they play in the well-ordered whole. This leads to a study of personal traits and characteristics that are peculiar to each individual; and the study becomes a thousandfold more interesting than it is when everything is reduced to the common denominator-man. In the past too much emphasis has been placed upon classification. There has been too little attention given to individuals and too much stress laid upon types. The type is a figment of the imagination. The typical animal or plant cannot do anything, because it does not exist. Such study, therefore, is uninteresting and profitless.

The most interesting thing about an animal or plant is its own peculiar methods of solving the personal problems that come up in its life. It is able to make its way in the world not more by reason of its likeness to other individuals than by its unlikeness to them. The most fortunate thing in life is to be born different from everything else; with just enough difference to have a unique point of view; to have novel ways of reaching results; to be able to see the opposite sides of questions presented; to be able to utilize what others waste; to have the ability to save when others lavish-these are the personal traits which contribute to the strength and virility of the individual, and it is through such that the race survives. Everything born into the world becomes the immediate possible progenitor of a line of individuals not more remarkable for their likenesses than for their power to vary from each other. It is by means of these fortunate unlikenesses that living forms have been enabled to take possession of every nook and corner of the whole earth.

While it is barbaric and unnatural therefore, to clothe everything in the garb of a man in order to study it, it is most desirable 
to treat it as a unique personality that has a particular mission to fill in the world's economy, and as having the power to devise special ways and means for accomplishing its work. Studied in this way, it becomes an actor with a definite part, not merely a cumberer of the earth.

It is safe to say that one rarely observes with care the habits of any particular creature without discovering that it has some peculiarity not noted in the books. The hunter and trapper, the breeder, the fancier, the keeper of pets, the man of science, each has his story that shows up the child of nature from his own particular line of approach. The following instances, taken from personal observation, will serve to illustrate the point:

I once was on more or less intimate terms with an old fox that had a large family of young housed in a deserted coal mine that entered the side of the hill about half a mile away. Naturally enough, the mother depended largely upon the farm-yard products for the maintenance of her family, and one time I had a chance to study her methods. She was observed, some distance away from the barn, stalking a flock of chickens. She simply walked after them, apparently knowing that if she became too enthusiastic in the pursuit, they might, and probably would, take wing. Finding that she was being watched, she bounded away to the den. Noticing a bunch of feathers lying in the course over which she had stalked the chickens, I proceeded to investigate, not doubting that I should find the mangled remains of a fowl. To my astonishment, instead, I found a rooster, with his heels in the air, lying on his back in a shallow hole, left by a horse's foot in the soft turf, and entirely unhurt. When I set him upon his feet, he ran away, no doubt much surprised to find himself alive. The fox evidently had put the chicken on his back into this hole, at the same time hypnotizing him into the belief that he could not extricate himself. Presumably he, by following this plan up, would have secured a full load of poultry before returning to the den to face the clamoring youngsters. I subsequently tried the same experiment upon a rooster, and found that by placing him on his back, as the fox had done, I, too, could make him lie still - but I learned the trick from the fox. I have never read of a similar observation, and cannot say whether it was a habit peculiar to this particular fox or not. 
One time, in a large city, I kept an opossum as a pet for nearly a year. It is a misnomer to speak of him as such, for he never seemed to appreciate in any way the attentions he received. One day in the summer he escaped, and for a time all trace of him was lost. The following spring, hearing that a man several blocks away had killed an opossum which he had caught in his chickenhouse, I visited the place and found that it was my unfortunate pet. The man said that he had been missing chickens all winter, but had been unable to find the marauder until he had actually lain in wait for him. The interesting point was to know where the creature had lived all these months following his escape. About half a mile away was a shelving rocky cliff formed by the construction of a railway tunnel through a hill. It seemed most plausible that he had sought shelter and refuge in this place, but one could not be sure. The important fact was that this stupid (?) little beastie, reared in the wilds of the Blue Ridge Mountains, with certainly no opportunities of knowing city ways, had managed to support himself and remain undiscovered for nearly a year, in the midst of thousands of his most deadly enemies. Could a human being under corresponding circumstances have done any better? Would a Japanese spy get along so well if he tried to live in Russia? Yet the opossum took just such chances in staying in the city, and he must have found it necessary to invent some ways of doing things that were new and strange to the "typical "possum." "

It is well known that the members of the pigeon family lay but two eggs. I once found a dove's nest in an apple tree that contained but one young one. While it was still quite small the mother dove laid a second egg. This one the young dove kept warm until it was finally hatched; by this time the first one was able to leave the nest. Whether this curious arrangement was made by accident or design it is difficult to say. The only advantage seemed to be in the fact that the nest did not have to be quite so large, nor the food supply at any one time quite so great. I have never seen it noted as being a characteristic habit of doves.

I recall an instance where a weasel produced a reign of terror in a certain chicken-house, and a reign of indignation in the household, for almost an entire summer before his whereabouts were discovered. The marauder was known to be a weasel from the peculiar way that the chickens were killed. In each case the throat 
was cut, and often there would be a number of victims in one night. One day while in the door-yard I saw something like a flash dart down a gatepost and enter a knot-hole on the side. Investigation revealed the devastator of the chicken-coop. This creature had managed to maintain itself on the fowls and to live within one hundred feet of the door of the dwelling, in a gatepost which was passed scores of times every day by the different members of the family. It appeared that he had the habit of entering the hole by coming down the post, and that he traveled to and from the chicken house on a fence so that he was safe from discovery by the dogs.

An even more remarkable case was that of a polecat that made her nest and reared her young almost to maturity in a pile of old fence rails that lay within a few feet of a path between the house and barn. There were two or three dogs about whose sole business was to look after "varmints," but this family was able to thrive undiscovered, and their presence was revealed only by an accident. Of course, this animal is nocturnal in its habits, but how, even so, it was able to leave and return to the wood-pile for almost an entire summer without once rousing the suspicions of the inquisitive dogs must always remain a mystery.

These animals adapted themselves to new and novel situations. It seems almost impossible to believe that they obey merely the instincts of the type, the traditions of the race. Apparently they had to invent ways of getting along that were made necessary by the strange and dangerous surroundings.

The knowledge acquired by working out the customs of individuals is more interesting and stimulating in the direction of further study than anything that can be gotten from books or from a more general study of types. The same principle must be applied to the study of nature that we observe in the study of human beings. No one is interested, except in a general way, for example, in the study of tailors as a class. But the study of how the individual tailor makes his way, by contriving special forms of advertising, by changing the cut of his clothes, and by other devices that are peculiar to himself, and which tend to distinguish him-these are full of interest. The same applies to all living things. The fact that they are on the earth today shows how skilful they have been in devising ways and means of self-support. Those less skilful are embalmed in the rocks as fossils or have utterly disap- 
peared. The survivors, therefore, should be objects of the greatest individual interest. In their field their skill outwits our own. Were we to attempt to live by the chances taken by a kingfisher, we should have to go to school to the kingfishers for a million years. It is only through the study of the personal life of the individuals that we can have that true nature-study upon which we must depend to broaden the sympathies of the children for the world of nature at large. 


\section{CHAPTER IV. \\ NATURE-STUDY AND EXPRESSION.}

In nature-study it is indispensable that adequate and intelligible records, corresponding to the different modes of observation, shall be carefully made and preserved. Few people seem to appreciate sufficiently the importance of appropriate and adequate expression. Teachers are apt to be content with having the pupils see, and then "tell what they see" in oral language, forgetting that the most and the best that they have to tell cannot be expressed in that way. The fear that the technical side of the various modes of expression cannot be mastered in the earlier grades adds materially to the difficulty. The fact is, however, that the mere technical or formal side of a subject is always the easiest part of the subject to learn.

Whatever may be the mode employed it is of the greatest importance that the expression shall be preserved carefully in the form of a record of the work done. Such a record is a powerful and a perfectly legitimate stimulus to further study and effort, and at the same time stands as a coherent history of what has been accomplished. In this way, also, a just basis is established for the judgment of teacher, parent, and pupil as to the merits of the work.

\section{COLOR.}

Among the records that can be made by pupils of all grades there is no one capable of a wider and more varied application than that of color. Of the mediums that may be employed, for simplicity and effectiveness water-colors are superior to others. With children and with all beginners this record has the highest value: first, because with children, particularly, nature exists as a thing of color, and it is through color that it makes its earliest appeal; second, because the simplicity of the materials used - water-colors - enables the children to express more fully and more graphically, by this means than by any other, what they see.

Fig. I shows one month's record in a pictorial history of the year in color. In the Chicago Normal and Practice School this plan was followed with various modifications for several years. Above 


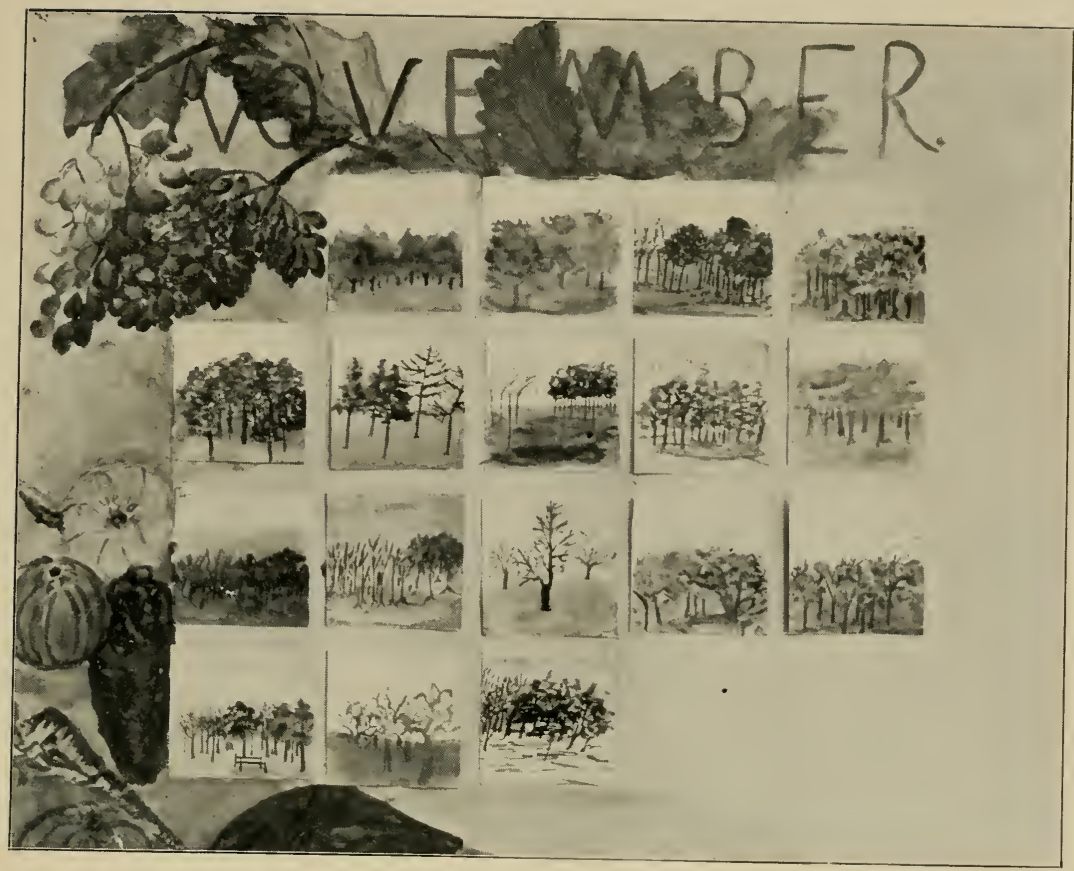

FIG. I.- Pictorial History for November. (Water Color.)

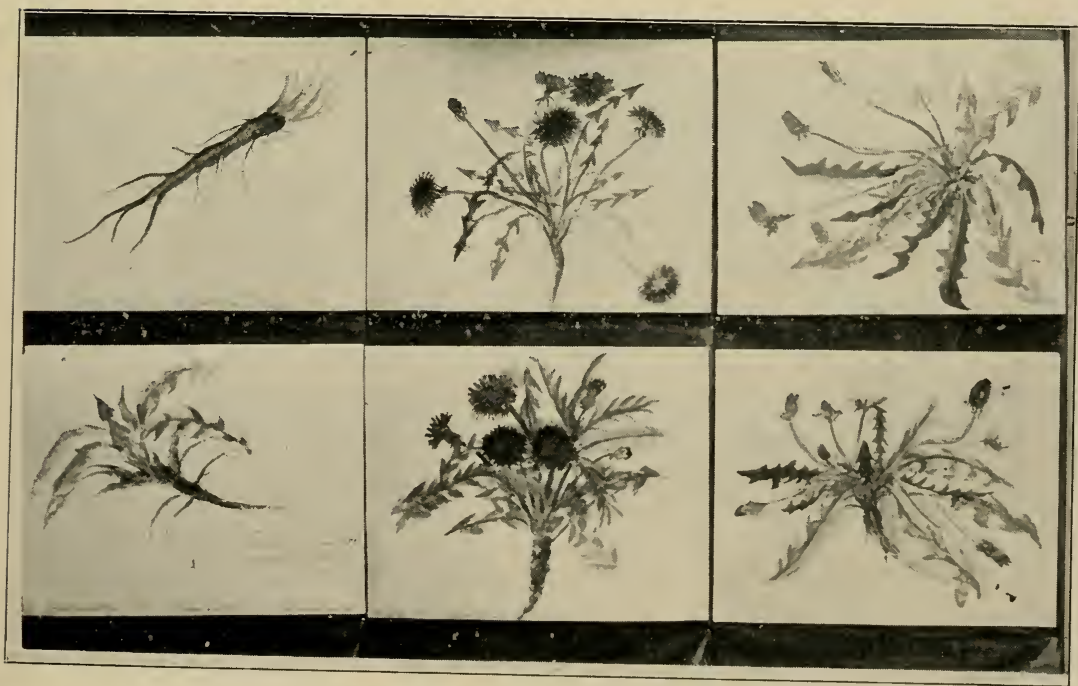

FIG. 2.- History of the Dandelion. (Water Color.) 

the fifth grade, the pupils daily painted the landscape, having chosen the time and place most convenient or that would best tell the story of the day. By vote of the children, that landscape was chosen which seemed to be the most faithful portrayal, and it was mounted upon a card. Fig. I shows the record of the month of November. Space forbids the reproduction of more of these, and the effectiveness is also much impaired by the necessary loss of color in the half-tone. As such cards are prepared, day by day and month by month, they form a record of the transient aspects of the landscape that is far more graphic and impressive than any other form of expression that can be used by the pupils. The series of cards for the year show with surprising clearness and with panoramic force the seasonal aspects that appear in color. No other form of record brings out so well those subtle changes, occurring from day to day and through the seasons, which appeal so strongly to the æsthetic sense. All are invariably filled with surprise to find the incessant change in the shades of green that sweep over the landscape during the summer. No two months are the same. The earliest tingeing of autumn shades strikes the treetops, and through a series of browns and yellows finally descends to the winter drab of the ground. In the spring the earliest signs of reviving life appear on the surface, and they gradually work their way, through a new series of shades, to the treetops again. In the winter almost the entire color effect is derived from the dead - the dried grass and weeds, the bark on the trees - and from the inorganic domain of nature - the ground, rocks, streams, bodies of water, snow, and ice. That this scene does not become a pulseless monotony through the long winter is very largely due to the infinite change in appearance that is wrought by its constantly shifting background - the sky. The rose and the pink, the purple, the lilac, the gray and blue of the winter heavens in the evening and morning, seem to be the finest of the year.

In the summer time color speaks of life and of work. Every hue and shade tells of something done - of a twig that has grown, of a flower, or of a fruit. No record of tongue or pen that the children can prepare will compare in its completeness and vividness with this history which they can write with the brush.

In descending to the details of the landscape the same mode of expression may be used with equal effect. In Fig. 2 there is given 
the history of a dandelion from its earliest sprout to the seed. This history finds an interesting parallel in the docks, thistle, cinquefoil, and many other plants that are in almost every vacant spot of ground.

In Fig. 3 the story of germination is told in a series of paintings illustrating the growth of the ragweed which infested a vacant lot adjacent to the schoolhouse. These plants were observed through the spring; and in the autumn, when school reopened, the children again went to the lot and finished the history by studying and representing the full-grown plant with ripened seed.

It has taken teachers a long time to find out how much more interesting it is to study germination when all creation is sprouting than it is when observations must be confined solely to windowboxes. The latter may supplement, but they should not take the place of, outdoor study. By the latter means only, when the plants are starting under natural conditions, is it possible for the pupils to find out the fundamental facts in germination. A seed represents a plant in a state of isolation. Germination and growth mean the establishment of definite relations with heat, moisture, and light. When the proper degree of heat is reached, the plantlet establishes relations with moisture, which it finds in the soil, by means of a root. A little later it forms its relationship with light by means of stem and leaf. The relative importance of these two relationships is indicated by the measurements of root and stem. Later, as the plant develops, the part that the leaf plays in the plant's adaptation to varying quantities of heat and moisture also appears.

The study of germination in this manner includes observations on the temperature of the soil at different depths, the moisture in the soil, the temperature of the air, and the distribution of sunshine and rainfall.

Another interesting detail of the landscape which may be studied in the same way is the development of branches, flowers, and leaves from buds. Fig. 4 shows such a record made by fifth-grade pupils from a study of various trees in the neighborhood. This history shows that in taking up the work of a new season the plants form a regular procession, in time, in which each has a tolerably welldefined place.

The bud, like the seed, has several interesting problems to solve. 


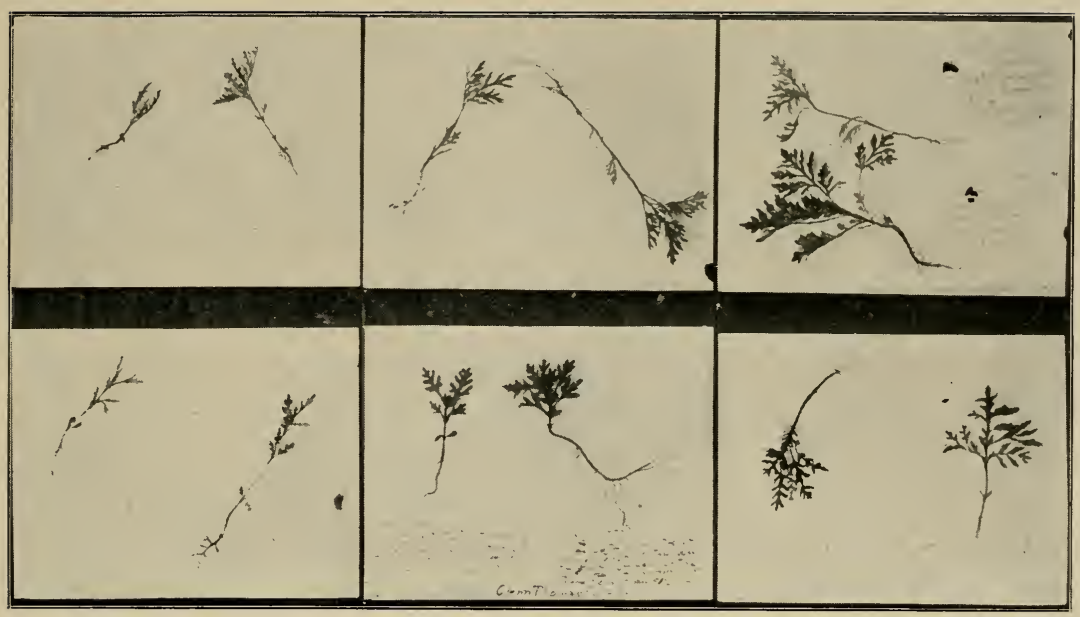

FIG. 3.- History of the Ragweed. (Water Color.)

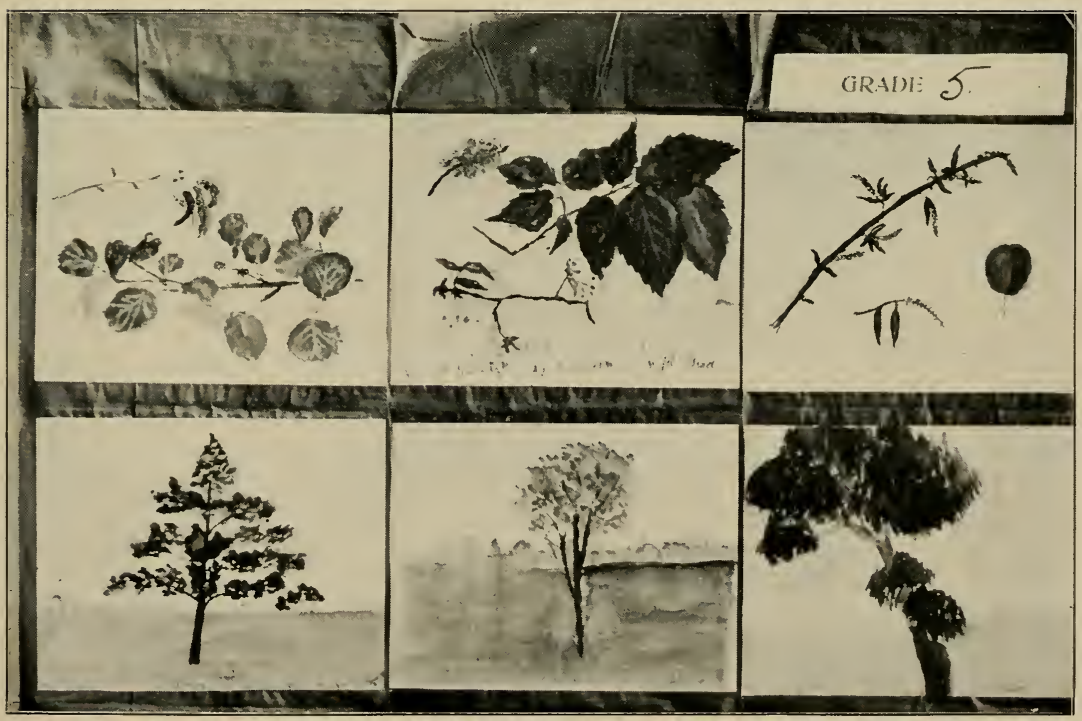

FIG. 4.- Development of Leaves. (Water Color.) 

It involves no small risk to unfold the tender leaflets and shoots to the uncertainties of early spring. The extent of the risk may be broadly imagined by the numbers of dormant buds that are held as reserves. In sundry ways each plant tries to checkmate the possible treachery of the elements. In some cases, as in the ash, the bud scales grow and attain considerable size, thus affording the early protection possibly needed. In others the stipules perform a similar office; and all seek to gain more or less time, before fully exposing the young leaf surface to the glare of heat and light, by a diversity of folding, wrinkling, and curling of leaves. The brilliant coloring of some young leaves, as in the oak and sassafras, probably expresses a heat-relation by means of which the young cells are able to extract a little more warmth from the sunshine, and thus give the plant the advantage of a little earlier start. This seems like a doubtful explanation in the case of the sassafras, at least, whose young leaves put forth in July are as highly colored as those are which start in April and May.

In addition to their work upon the landscape and its details, many of which limited space forbids even mention, the pupils for several years had under observation an area known as the school garden. A view of this is given in Fig. 5. The garden was about 40 by 50 meters, and contained approximately half an acre. It was divided in various ways to suit changing conditions, but always in such manner as to give each grade, from the kindergarten up, a fair proportion of the ground to care for. It is a great point for the teacher to recognize the fact that children's interests are by no means all identical in nature-study. None are lacking in all interest, but very few interests run exactly in the same channel. The value of the work is much enhanced by throwing open the whole field to the pupils. Some of them, therefore, have been allowed to follow up certain phases of the garden-work, while others have devoted themselves more closely to the wild plants or to the birds or insects. As the different pupils report "1pon their work, however, there always appears a considerable community of interest, corresponding to the interrelations that develop among the things studied.

In autumn the color record becomes, if possible, more varied and richer. The landscape changes are more vivid and striking. Insect life is at its best. Caterpillars in almost endless variety 
afford continued entertainment, and through their curious habits initiate the children into some of the most interesting of life's mysteries. Fig. 6 shows some of these studies. One is that of a caterpillar that found its way into the schoolroom, and in seeking the upper corner of the window frame in order to spin its coccoon, for reasons possibly known to itself, certainly not to the observers, it spun for itself a kind of Jacob's ladder on the window pane, by means of which it climbed to its destination.

Another is that of the sand spider which the children dug out of a sand dune at a depth of two feet. This little creature had walled up its chimney-like burrow with a finely woven web which prevented the loose sand from caving in upon it when, relatively, as far below the surface as a man would be in one of our deepest mines.

A third study shows the larva, a caterpillar, which has itself become the unwilling and luckless host that supports two or three score of smaller larvæ, which now have spun their tiny white coccoons on the outside of its miserable and shriveling body. A fourth shows how some of the insects have successfully run the gauntlet so far as to be sntigly ensconced in their winter garments - the coccoon. But whether they shall escape the lynx-eyed, hungry blue jay, and emerge in the springtime in the glorified garments of their final transfiguration, no one can tell.

\section{DRAWING.}

There is a good deal of confusion in the minds of most teachers as to the relations of painting or color-work to drawing. It is evident that both modes of expression, as such, have certain elements in common. For example, form in two dimensions must be expressed by both. It is equally clear, though, that there must be some points of fundamental difference, and the failure to recognize these leads to undiscriminating and vague use of both. The function of any mode of expression depends upon the nature of the image. In this case it would seem, therefore, that when the function of the thing observed is expressed through color, wholly or chiefly and the image thus is largely visual painting is the proper morle to be adopted. But in cases when the color is secondary in denoting function, and when outline is primary, and the image is therefore chiefly motor, then drawing is the most direct mode to 


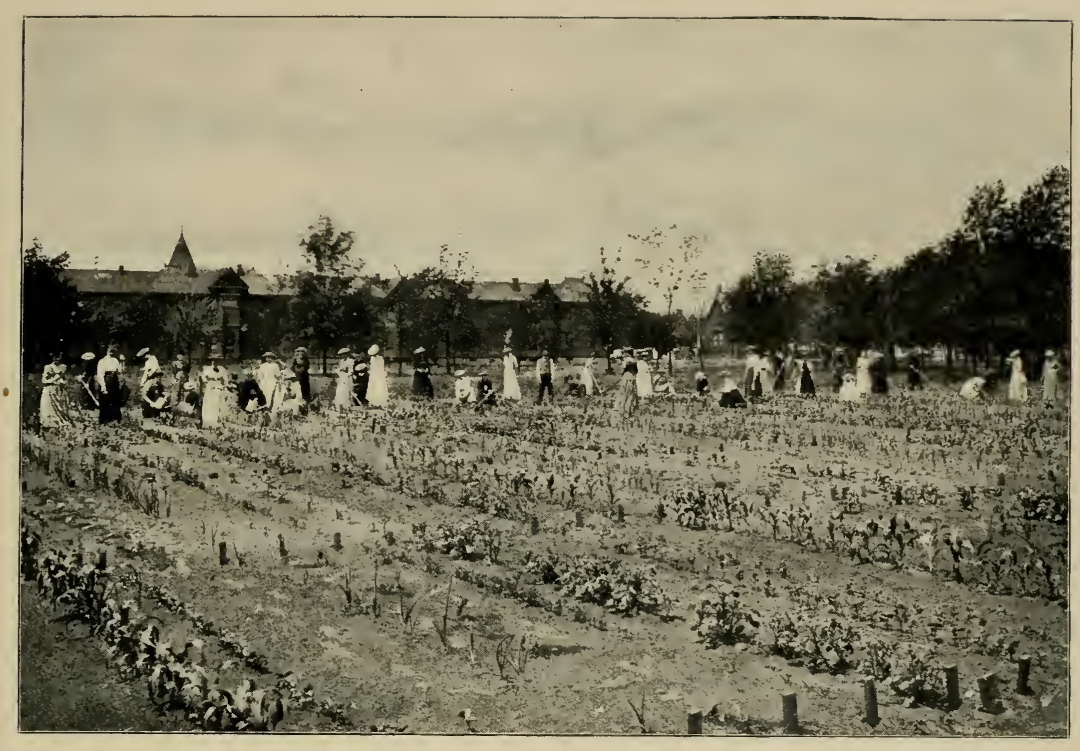

FIG. 5.-The School Garden.

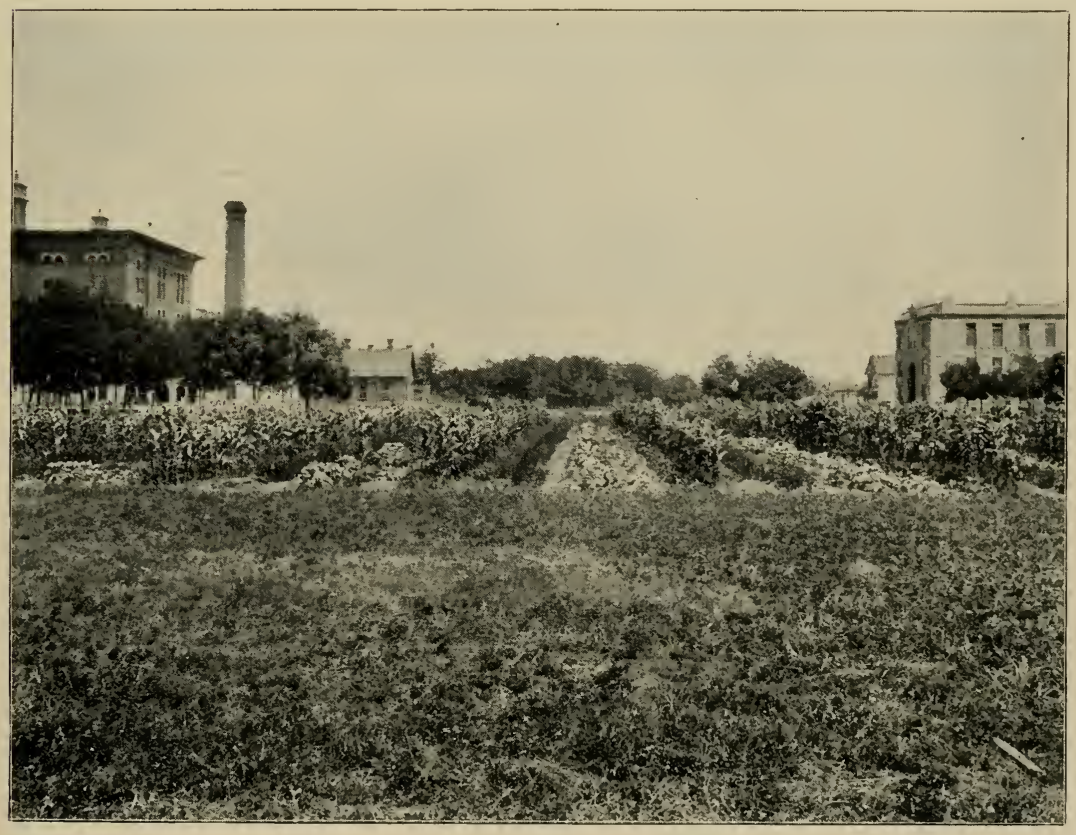

FIG. 5a.-The Same Garden in the Month of June. 



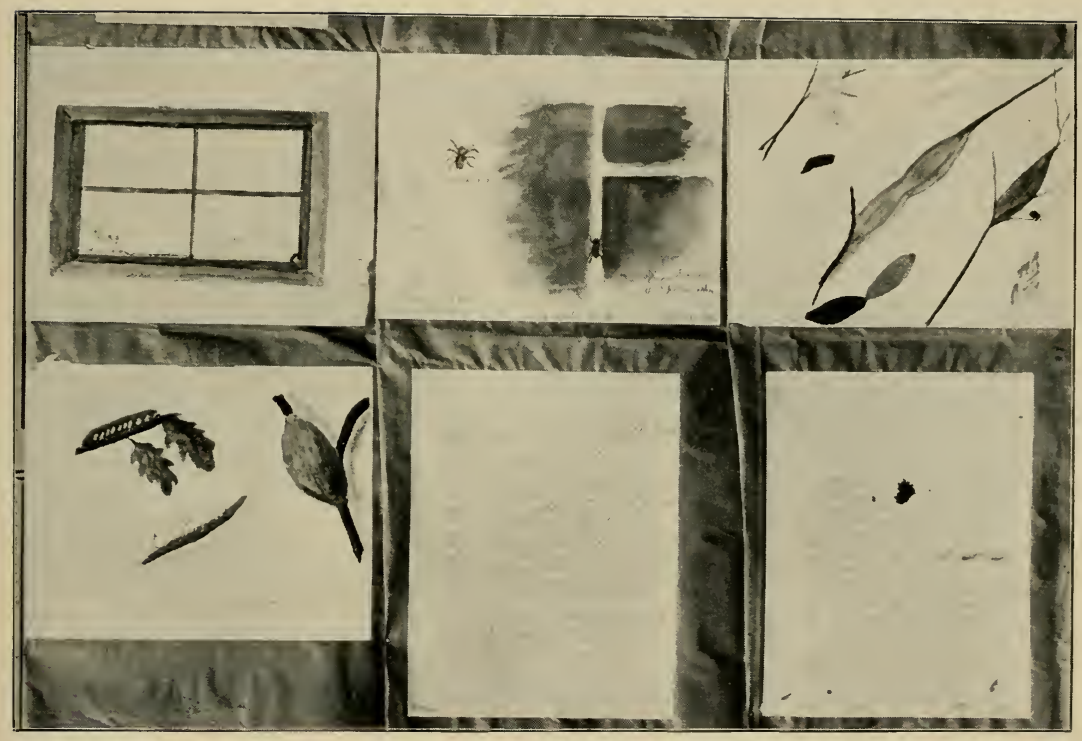

FIG. 6.- Paintings with Written Work. 

be used. As an illustration of this point, it may be said that when a child sketches a tree in winter with its bare branches, color plays a secondary and unimportant part; but the outline of the tree, by the direction of its branches and the contour of its top gives rise to an image involving direction and distance, and the image is therefore chiefly motor, and drawing is the direct and appropriate mode of expression. But in the summer, when the life of the tree is shown in the color of the leaves, the contour of the top and other outlines are secondary; the image is chiefly visual and painting becomes the appropriate mode.

\section{MODELING.}

The relation of both these modes of expression to modeling is obvious. When the function of the thing is expressed wholly or chiefly only when the third dimension is taken into account, then the image becomes motor, and it is clear that modeling is the directly appropriate mode of expression. For example, in the case of a fruit, the chief function is not dependent upon either color or outline, but upon the form in three dimensions. The image is, therefore, motor; and since the three dimensions are involved, modeling is the mode that should be used. If, now, color, too, plays an important function, as it does in the case of some fruits, then the model should be colored also, because an important aspect of the image is visual.

\section{MAKING.}

The great value of making, which is here intended to include all forms of manual training and constructive work, lies in the fact that the thing made need not be constructed in accordance with any model or pattern. In painting a landscape, the result, to be rational, must embody the essential features of this or that area, or it may be a composite of many areas. But in building a conveyance, for example, the maker is at liberty to invent a form never yet beheld by anyone - the only prime requisite being that it shall perform its function better than any other conveyance already built. In this respect, mechanical drawing is closely allied to making.

Nature-study opens up an exhaustless field for manual work, not only in the construction of apparatus, but in the performance of experiments in physics, chemistry, and other sciences, all of which require the constant exercise of the inventive function of the mind and the greatest manual skill that the pupil can command. 


\section{READING AND WRITING.}

It is needless to dwell upon the fact that the chief reasons why reading and writing become irksome tasks are that the form side has been emphasized at the expense of interesting content. The ordinary school-work does not furnish a great demand for the use of these particular tools. In order to illustrate the part that these subjects may play in nature-study from the earliest steps in observation, the following lesson is given with a summary showing the way in which it was prepared and something of its educational value:

\section{READING LESSON ON THE FARM.}

November 2 we went to visit a farm.

It was a beautiful day.

Deep-blue sky above us.

Not a cloud in it.

Cool fresh air around us.

Bright warm sunshine all day long.

"The nicest day of all the year!" said Fritz.

The farm we visited is fifteen miles from our school.

It is on Halsted Street.

We might have gone all the way out in wagons.

That was too slow for us.

It took us forty-two minutes to go to Thornton, on the train.

Then we were only one mile and a half from the farm.

Big hay-wagons were waiting for us at the station.

Oh, what fun we had going to the farm!

We passed a big limestone quarry.

We wanted to see it.

But we could not stop for that.

We passed some beautiful oak woods.

We wanted to gather leaves.

But we could not stop for that.

We passed a great yard full of horses and colts.

We wanted to watch them.

But we could not stop for that.

We passed cows and calves, goats and little pigs.

We saw old hens and chickens, and a big, proud peacock.

But we could not stop for any of these things.

They needed our horses at the farm, you see.

After a while we came to more beautiful woods. 
We heard turkeys gobbling.

We saw a red-brick house.

We were at the farm.

'i he people at the farm were very kind to us.

They came out to meet us.

They let us go everywhere.

They let us see everything.

We went first to the horse-barn.

We saw each horse go into his stall.

They were fine, large horses.

They were black, white, and brown.

Some of us liked the white one best.

Some liked the big black one best.

In each stall was a manger full of hay.

We saw the horses fed and watered.

We saw them hitched up for work.

The man showed us how he kept the horses clean.

He combed their hair with a curry-comb.

One boy said: "I am glad my hair is not combed that way!"

The man showed us the hayloft full of hay.

He showed us the oat-bin full of oats.

Then we went to the cow-barn.

The cows were out in the cow-yard.

That was back of the barn.

There were twenty-five cows in the yard.

In the barn was a little black and white calf.

It was only two days old.

Its mother was in the yard.

She kept calling it.

It always answered her.

"Moo! Moo!" said the old cow.

"Maa! Maa!" said the little calf.

We wanted to stay and watch him.

But there were many things to see yet.

We had to go on.

We saw all the food for the cows.

There was ground corn, and oats.

There was plenty of hay and corn fodder.

Corn fodder is the dry stalks and blades of corn.

We saw the stalls where the cows were milked.

They were not like the horses' stalls. 
There were no mangers in them.

There were slats to hold the cows' heads straight.

Why do people wish to hold the cows' heads straight?

We saw much straw for the cows' beds.

In summer the cows sleep outdoors.

Then we went to sec the pigs.

They grunted and squealed when they saw us.

"Give us something to eat," they said.

We ground corn for them in the corn-grinder.

We fed them some of our lunches.

Still they grunted and squealed.

Pigs never seem to know when they have enough to eat.

They would eat all the time, I think.

Then we went to see the machines.

There was a shed full of them.

There was a ground-roller.

We rode on that awhile.

There was a drill to make holes for the seeds.

There was a hay-rake and corn-cutter.

There were a great many other machines, but we did not see them used.

Then it was noon.

We sat down outdoors to eat our lunches.

Some of us sat on pumpkins on the porch.

Some of us sat under the trees.

It was nice to look up at the blue sky.

We had to look out through the red and yellow leaves.

There was a large woods across trom the house.

Oh, there were such pretty leaves on those trees!

The oak leaves were purple, brown, and red.

The maple leaves were bright yellow.

The pines were deep green.

After lunch we ran over into the woods.

We played games and climbed trees.

We filled baskets witlı acorns for Bunny, our squirrel.

We gathered pretty leaves to take home to mother.

We saw a man cut down a pine tree.

First he cut a notch all around with his ax.

Then he cut in deeper and deeper on one side.

Down came the fine tree.

We wondered why he cut it down.

One boy said: "It's for a Christmas tree." 
Do you think it was?

Another said: "Oh, they want to get the pineapples."

He thought the cones were pineapples.

That was a joke. Do you know why?

We went to see the man plow a field.

It took three horses to draw the plow.

The plow-knife was round like a wheel.

It cut through the sod.

The plowshare was behind the wheel.

It was made of bright steel.

It turned the soil over.

It was a long, long field, but we went to the end of it.

The soil by the house was sandy, but this soil was black.

We brought some of it home.

It is not like our garden soil.

At four o'clock we all got into the hay-wagon again.

"Good-bye, pretty woods," said one girl.

"Good-bye, nice farm," said another.

"Good-bye, and thank you," we all said to the kind people.

Then we came home.

Was it not a nice day?

In summing up this lesson as to its educational place and function, the following points may be noted:

I. The day's observations of a widely varied character, enlisted the equally varied interests of the pupils.

2. When the pupils returned for days, perhaps weeks, they were permitted - invited - to tell the stories of their experiences.

3. They were confronted by the fact that the oral story could not be held strongly in mind, and they at once appreciated the real function of writing as a means of keeping a record.

4. The teacher at first wrote these stories, as they came to her, on the blackboard. This was the strongest possible stimulus for the pupils themselves to make the effort to write. It is of the utmost importance that the teacher be a clearly legible and rapid writer, so that the pupils may have as nearly as possible the perfect copy.

As to the method, the teacher wrote the entire sentence or story. After the opportunity of a minute or two had been allowed the pupils for examination, it was erased and they were permitted to try to reproduce it from memory. If they failed, as they always did at 
first, the sentence was rewritten, and repeated trials were permitted until the pupils could reproduce the story. This was to induce the pupils to grasp and hold the entire thought and the complete forms that embodied it, and to prevent that painful copying, letter by letter, which is the bane of the old copy-book method.

5. As the stories were written on the board, they were read by the pupils. These were interesting to all, because each generally contained some bit of a picture that had partly or wholly escaped the attention of others, and then writing and reading were both given immediately their proper function.

6. It was soon evident to the pupils that the order in which the stories were told by the class was not the best to express the experiences of the day as a whole. They then selected those stories which bore upon the same point and grouped them together, forming something of a chapter. Within this chapter, too, they arranged the stories in the most effective sequence.

7. When this work was done, the stories were copied upon paper and sent to the printing-office. In a day of two it came back in large type. It was a matter of some conjecture as to whether the pupils would care to read the story, now, after having dealt with the details so fully before printing. But the doubt was immediately dispelled. There was the most eager desire to read partly, no doubt, from the novelty, and from the fact that each had contributed to the composition, and therefore had a desire to see himself in print; but, in the main, because through the reading they actually lived the day over again. In this way the reading performed its perfect function as an aid in imaging.

Of course, the pupils did not recognize all the words - perhaps not more than half of them. Their eagerness to get the meaning, though, rendered them alert in getting the new ones; and the meaning was clear to all. Teachers are frequently so overconscientious in making sure that the pupils get every word that they spoil the spirit of the reading. Nobody is ever expert enough to be perfectly sure that he will know either the pronunciation or meaning of every word on the page of the ordinary newspaper, magazine, or book. Yet we get the sense from the context without this final detail of meaning, and we get from the page all it was intended to give. The same rule should apply to the children. The nature 
picture is the thing to be developed, and the reading must be, and it is, a useful means, not a hindrance, to that end.

8. When the work of the school, in reading as well as in other subjects, can be printed, as it was in the present instance, the pupils can be given an opportunity for bookbinding. In the present case, an old book was soaked and the cover removed, and the different parts were separated so that the pattern could be obtained. Then, with cardboard, and paper suitable for the covering, and leatheret, the pupils constructed a back that held a number of short stubs of leaves. To these, they pasted the printed sheets, as they were prepared, and thus built up their own reader and text-book.

Reading taught in accordance with the principles suggested above becomes of immense service to nature-study, and it is also much more. It makes a direct appeal to the literary taste. Not only does it create a taste for what others have written, but it lays the basis for literary composition by the pupil himself. The two following reading lessons on "Sunrise" and "Sunset" are a child's original expression concerning two sets of natural phenomena that have given to literature some of its choicest gems :

SUNRISE.

I saw the sunrise.

It was beautiful.

Some clouds were red.

Some clouds were white and pink.

Some clouds were golden.

The sky was blue.

Then the sun came.

I could not look at it.

It was too bright.

'The birds were singing.

The dew was on the grass.

The sun rose in the east.

That way is east.

SUNSET.

That way is west.

The sun sets in the west.

I saw the sun setting.

It was beautiful.

It was large and red. 
I could look at it.

Some clouds were golden and pink.

Some clouds were white and fleecy.

The white clouds looked like ships.

The sky looked like a great still lake.

Will you look at the sunset tonight?

Teachers of nature-study too often imagine that their work ends when the senses have been employed in observation. Pupils are tanght to observe for themselves, but they are generally given the impression that for the literary and artistic aspects they must depend upon others. Hence, while they see for themselves, they read the poetry and sing the songs of other people. This is as bad as it would be to have them depend wholly upon the observations of others. The literary and artistic impulses are roused in the children by nature, as they have been aroused in older people before them, and it is the teacher's business to nurture and develop the appropriate forms of expression in the children themselves. This cannot be done by having them always read what has been said any more than they can be taught to observe by telling them what someone else has seen. A field trip has not been wholly successful if it does not rouse the artistic feelings - if it does not stimulate them to paint, or lift them up to the use of the best language; or if it does not furnish the spirit for a song. The chief reason why these results are not secured is that teachers pay no attention to the foundations which nature-study lays for them. These impulses in children are easily roused; but, uncared for, they soon wither and die, never again to reappear. Hence, the dull and prosaic life, instead of one rich in feeling, in sympathy, and in appreciation of both nature and man.

\section{MUSIC.}

The following song was composed under the direction of Mrs. May Root Kern by a class in the Laboratory School of the University. Song-writing should be almost as common an expression in connection with nature-study as drawing or written composition. 

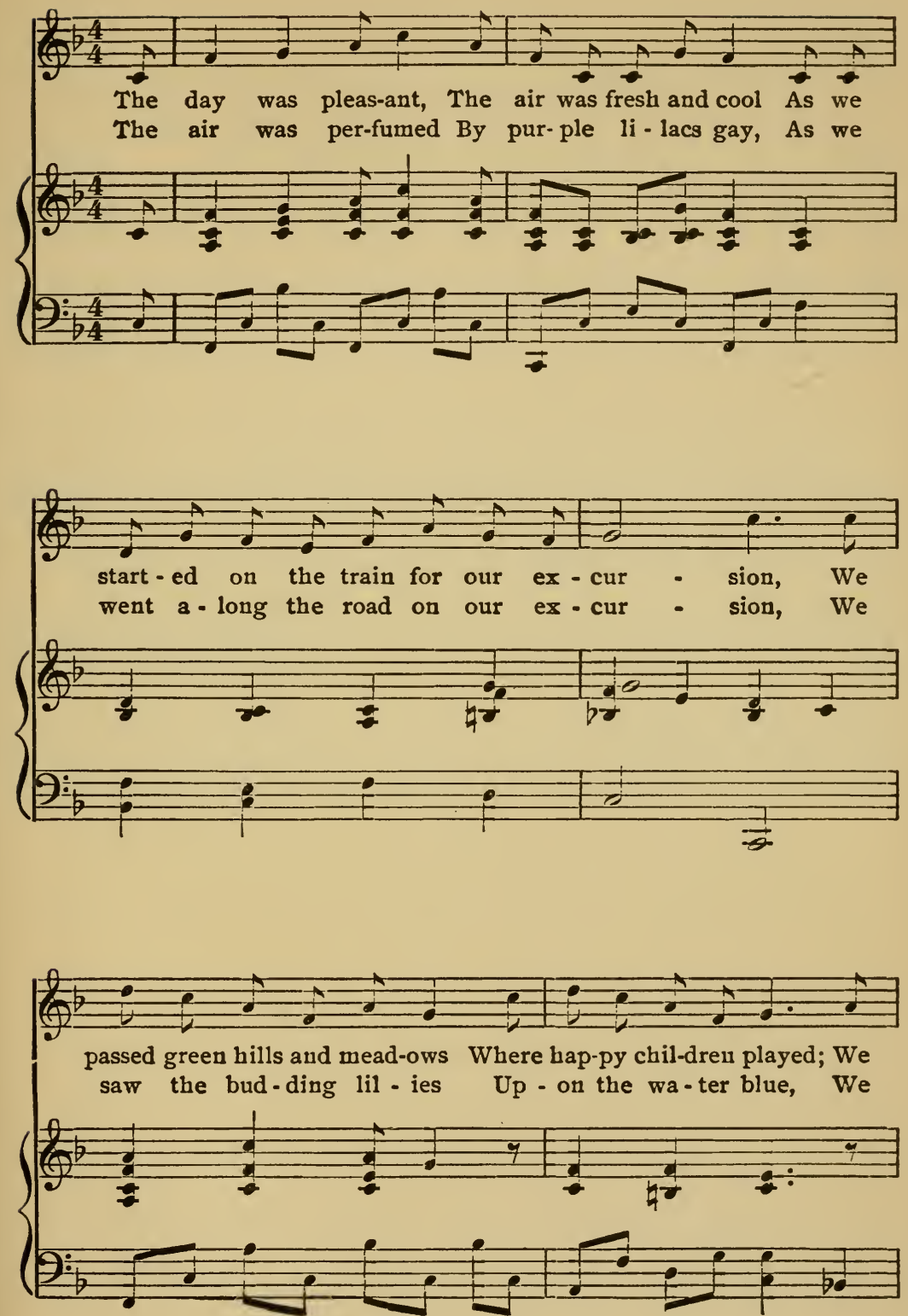


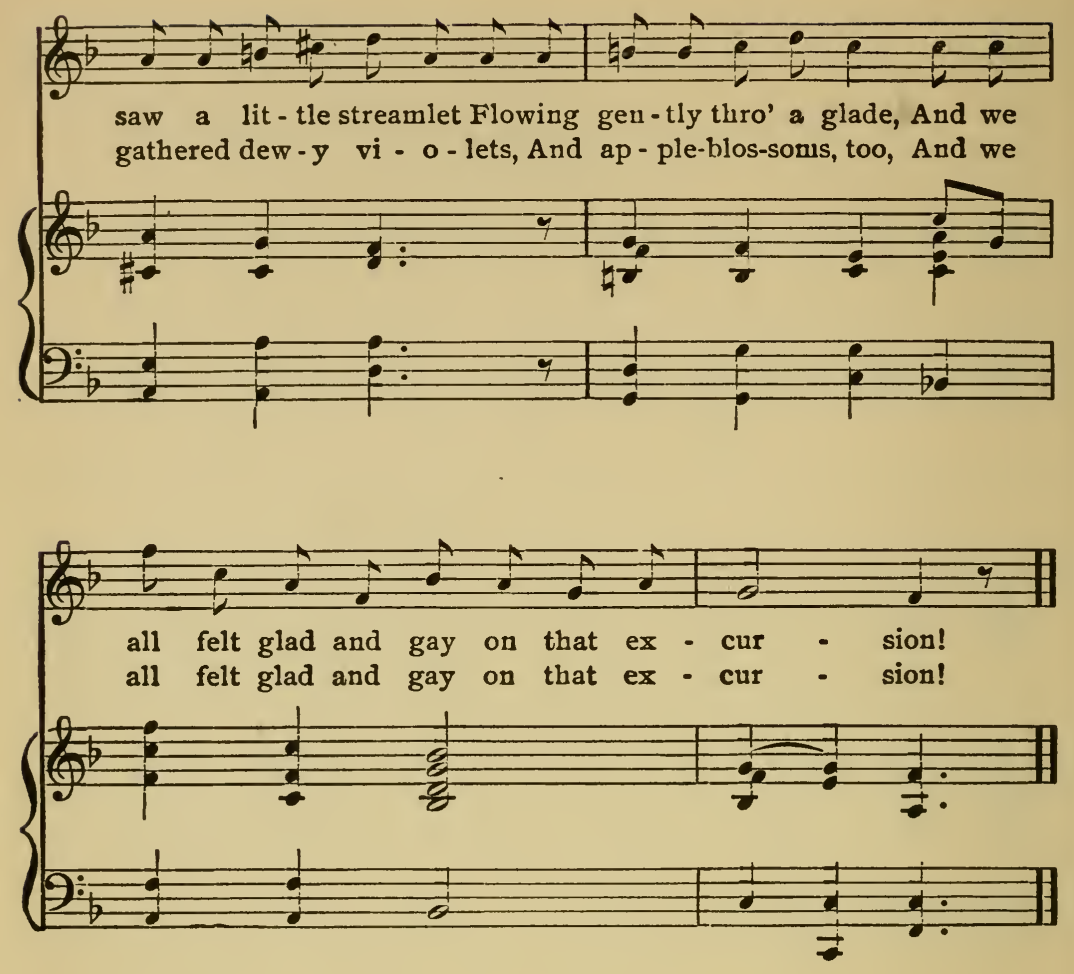




\section{CHAPTER V.}

\section{NUMBER-WORK IN NATURE-STUDY.}

IT is the function of observation to define a mental picture or image. By means of number the image is defined through a determination of quantity. In the application of number therefore, the same principles must be observed that are employed in defining the image by other means.

I. There must be a clear idea concerning the image to be defined. - If, for example, a pupil is required to find the number of barrels of water in the rainfall of a given area, he should know beforehand how this result is to contribute to the nature-image that is being developed. The life-conditions of a given area are largely affected by the rainfall. By finding the quantity the student determines exactly the value of that particular factor, which enables him to make definite comparisons with other areas, or with the same area in different months or years.

2. There must be an appropriate selection of units of measurement.- The units chosen must be such as will involve the pupils least in the details of process, and which, at the same time, will best approximately define the image.

Pupils in the early grades should deal with quantities of large amount. For example, the amount of water in the soil found by drying out one cubic inch might serve the purpose with an adult, but it would make practically no impression on young children; whereas the picture might be made very interesting if in the latter case a bucketful of soil were used. The bucketful would be, perhaps, as much as the pupil could lift, and might weigh ten pounds. It would be much easier to get numerical results that would be intelligible if pounds were used, than it would be if ounces were employed. So, too, yards in many cases would mean more than feet or inches.

3. The most expeditious methods of measurement should be adopted.-Estimate, then measure. Neglect the fractions that do not stand for an actual image in the pupil's mind. This will fix naturally the limits of the decimal. If a hundredth of a pint 
possesses no significance to the pupil in his image of the quantity involved, then neglect it. Fractions should be taught along with whole numbers when they assist in determining an actual image not otherwise, any more than a useless or meaningless word. Common and decimal fractions should be taught from the beginning. The difference is merely one of written language.

4. There must be careful selection of the processes by which the comparisons are made.-This will be determined by the pupil's ability to picture and use the different standards of comparison. The earliest processes will be addition and subtraction; then fractions; later ratio and percentage.

5. The results obtained must be represented objectively until they will be habitually imaged.- Thus, if it is found that a cubic foot of soil contains three gallons of water, $(a)$ the actual size of the cubic foot must be shown (by a model or otherwise), and (b) the water must be actually measured and put into some convenient receptacle. In the same way, the units yard, foot, inch, acre, mile, square mile, etc., etc., must be actually seen until they become a part of the mental equipment. They should be ready for immediate use, just as the color green or red is always ready when needed in our thinking. Represent proportions by diagrams and models.

6. Using the results obtained as data, a great nature-picture must be constructed.-By calculation, the real magnitude of the world-operations should be brought out with all possible distinctness. For example, a certain series of rainstorms that crossed the United States gave an average depth of five and one-half inches of rainfall. This amounted to nearly three and one-half gallons of water per square foot of surface. (The result should be shown objectively, as suggested in 5.) When the amount of water is calculated for the entire area, the mind is staggered at the quantity. It would fill a hole having a cross-sectional area of twenty acres, about two thousand miles deep. Athough the quantity of water is so enormous, it fell as rain not only harmlessly, but in such a way as to greatly revive and refresh the earth. There is no other means of opening up these world-pictures to the pupil except through the intelligent use of numbers.

It is useless to merely enumerate topics in nature-study which require number-work. The number-work is not required in fact, unless the topics themselves are fully worked out. A random use 
of number with nature-study materials is as bad as the present sterile array of problems in the ordinary text-book in arithmetic. There will never be any such thing as rational mathematical work until it is confined to the appropriate part it plays in the development of an image.

One of the chief obstacles to intelligent number-work is the deep-seated feeling in the minds of most teachers that a large amount of drill-work is necessary in order to fix the process. That much repetition may be necessary does not imply, however, that it shall take the nature of drill on empty and meaningless forms. The same principles apply here that apply to reading. It would be just as senseless to isolate the words of a lesson and require the pupil to learn them all by rote before learning to read, as it is to isolate a lot of facts in the form of the multiplication table or the tables of compound numbers and require the pupils to memorize them. That both words and certain results in arithmetic must be memorized no one will dispute, but there is no reason for doing one thing with words in reading and another thing with number.

The tables of various kinds in arithmetic should be built up just as a vocabulary is formed. When a word is used by the pupil in the development of an image, the teacher usually, as she should do, makes an effort to fix the word in the mind. If the child fully understands its function in the development of his image, it is comparatively easy to do this; otherwise it is not readily done. So in number, if the development of the image requires that the pupil get the product of 6 times 8 , when the result, 48 , is obtained the operation should be fixed in the same way that the word is memorized. In fact, this part of the work is nothing but a language lesson, and it should be treated as such. If from day to day these operations are all gathered up and tabulated as they occur, the tables will take care of themselves.

The real point of importance that is involved here is a moral one. No one has yet been able to calculate the evil done to the pupil by enforcing the current drill methods in arithmetic. By this practice it habituates the pupils to dealing with forms without meaning - to blindly doing things from which they expect no intelligible result. If we were to practice the same methods in teaching reading, if we were to "drill" the pupils upon words without meaning for year after year, as we now drill them year after year upon 
processes which lead to senseless or meaningless results in arithmetic, we should engender the same indifference, not to say hatred, to literature that now exists in regard to mathematics. Why is it that when pupils leave school they always have more or less taste for their literary studies while not one in ten thousand even attempts to "keep up" his mathematics? Why is it that at a certain point in the academic course students have sometimes instituted the custom of publicly burning their calculus? Why is it they have never thought of burning their Shakespeare, or Milton, or Tennyson? There is no reasonable answer to these questions, except that in the one case the study of literature has been made to contribute something to their lives of real value which they are able to appreciate, while in the other case they have got nothing. Everybody clings to that which really helps him grow, and the fact that the great majority of pupils who leave school either detest mathematics or are in a state of helpless despair about the subject is enough to make the philosophers who are inundating us with volumes on the psychology and pedagogy of the subject stop to think. They have surrounded the subject with so much mystery that most teachers are no longer even curious about it, and they have given up trying to penetrate it. There is no more mystery about the psychology of number than there is about the psychology of reading or drawing or any other subject. The fact is that there is no psychology of any subject- it is all the psychology of thinking. It is simply a question of finding out what image the pupil has that is worth developing, and then of helping him to the use of tools, as he needs them, in its growth. Mathematics plays a distinct part in image-development which any teacher of ordinary sense can recognize. It is nothing but the blindest slavery to tradition that keeps the pupils from a rational use of number. It is due to the general prevalence of the antiquated notion that in these early stages of education it is necessary to isolate in a meaningless way the process side of the subject for the purpose of drill. It has been shown very clearly, both in theory and in practice, that the pupil does not get by this method that mental discipline that is supposed to come with the study of mathematics. It is evident that this must be so because, as before pointed out, the drill is necessarily much more a matter of language than of number; the drill fails even as a linguistic exercise because the language is 
meaningless. With the disciplinary idea out of it, the ancient method of teaching number that still so largely prevails has not a single foot left upon which to stand.

The lessons given here are submitted as illustrations only. They are worthless to any except those pupils who actually made and recorded their observations. The work was done with great deliberation and covered many weeks, because great nature-images grow slowly with children. The lessons in this connection, are only intended to illustrate what has been said as to the function of number in defining an image.

I. THE DISPERSAL OF SEEDS.

An attempt is made to form some idea of the rate at which plants might multiply, as indicated by the seed-production.

I. Near the schoolhouse a vacant city block rather thickly covered with wild verbenas was selected for study.

2. By measurement and calculations this area was found to contain approximately one-fourth of an acre.

3. Areas of one square yard each were measured in various places and the average number of plants was calculated.

4. An average of thirty plants per square yard gave approximately 36,000 to the quarter acre.

5. Each seed pod contained four seeds, one of which, on the average, it was found, failed to mature. The number of pods on a spike was counted, which, when multiplied by the number of spikes, gave 2,300 seeds as the average number produced by each plant. Since only three-fourths of the total number matured, each plant furnished, therefore, (approximately) I,700 good seeds available for growth.

6. If these good seeds were properly distributed, and if each were to produce a plant, the one-fourth of an acre the second season could populate 425 acres - approximately two-thirds of a square mile; $i$. e., equal to an area bounded by Cottage Grove Avenue and State street on the east and west, and Sixty-third and Fifty-fifth streets on the north and south.

The third season, under the same suppositions, enough seeds would be furnished to populate I,I22 square miles; $i$. e., more than six times the area of Chicago.

The fourth season, under the same suppositions, the area popu- 
lated would be $1,907,400$ square miles; $i$. e., equal to about thirtyfour times the area of Illinois.

The fifth year the number of seeds would be sufficient to furnish plants as thickly as those found on the quarter of an acre for an area equal to sixteen times that of the entire earth.

These measurements and calculations give $(a)$ an idea of the vitality and the tremendous push and rush of the living things; (b) since there is no such increase, as an actual fact, they indicate the degree of failure on the part of the plant to get its seeds properly scattered and safely planted, and also the enormous resistance offered by other plants and climatic agencies to the growth and spread of the verbena.

II. SEASONAL CONDITIONS: WERE THEY FAVORABLE OR UNFAVORABLE?

I. Rainfall.-One inch of rainfall furnishes 540 fifty-gallon barrels of water per acre, or I35 barrels for the quarter acre. During the month of May, June, July, August, and September, where the verbenas grew, the rainfall due the plants, according to the thirty-year average given by the Weather Bureau, is I6.I inches, or 2,229 barrels. The actual rainfall for three months in I90I was 13.9 inches, or 1,874 barrels. There was, therefore, a shortage of 2.6 inches, or $35 \mathrm{I}$ barrels. That is, from this cause alone the vitality of the plants was reduced by about 16 per cent. This may be viewed in different ways: (a) that only about eight plants out of ten would grow this season; or (b) that eight seeds out of ten would mature; or $(c)$ that the general vitality was lowered, which would be felt the following season.

2. Sunshine.-The Weather Bureau records for the past eight years show that this region has received 65 per cent. of the sunshine possible during the months under consideration. In the year I90I this area received 68 per cent. of the possible sunshine. It follows therefore that, since plants are most active in sunshine, there was an overstimulation of 3 per cent. above the normal. Since, also, during sunshine plants are most active in the transpiration of water, and since there was a shortage in the supply of I6 per cent., it follows that the combination of these two causes operated to intensify the strain upon the plant. The plant endeavors 
to resist this strain by reducing the leaf surface exposed to the sunshine.

3. Temperature.- The average temperature for the five months for thirty-one years is 66 degrees. For the year Igor the average temperature for the same month is 68 degrees. There was actually, however, an excess of 6 degrees during this time, as shown by the Weather Bureau records. This condition meant, also, not only a possible increase of plant activity; it meant more than the normal evaporation from the soil which would tend to cut off the water supply from the plant.

4. Variation in intensity of sunshine.- On the twenty-first day of each month the distribution of a given beam of sunshine at noon is proportional to the following areas: May, Io8; June, I05; July, I07; August, II5. These results are obtained approximately by the use of the skiameter. The intensity of the sunshine varies inversely with the areas of distribution. In the month of June, when the intensity of sunshine is greatest, the average cloudiness is 32 per cent.; in I9OI the average cloudiness was 3 I per cent. Therefore the withdrawal of the friendly cloud shelter by the amount of I per cent. in the month when the intensity was greatest served still further to increase the stress laid upon the plant in the year rgor.

These causes all happened to combine directly in this particular year to menace the future of the verbena. They also operated indirectly, so far as they favor other plants that know how to get along with the reduced amount of moisture and the increased amount of sunshine and heat.

The botany of the verbena, therefore, for this particular year, becomes chiefly a study of the various devices of leaf, stem, and root by which this plant is able to maintain itself against all these unfavorable influences, which the work in number shows to be actual and definite forces of enormous power.

As an illustration of the point; already urged, that the form side of the subject should be studied as the image-growth proceeds, it will be found by an examination of the lessons that the following processes have been involved, which should be formulated or tabulated in any convenient fashion (and learned) as the study proceeds:

I. Reading and writing of numbers up to and beyond six places.

2. All the fundamental operations. 
3. Fractions: common and decimal; fundamental operations.

4. Percentage: all the processes or "cases."

5. Square measure, units: acre, square rod, square yard, square foot, square mile.

6. Linear measure: inch, foot, yard, rod, mile.

7. Volume: pint, quart, gallon, barrel.

A word further must be said as to the method of teaching these forms and processes in connection with the actual imagedevelopment. Most teachers are so overconscientious about the matter, to put it charitably, that when a pupil fails to learn the processes at once, he forthwith drops everything else and proceeds to belabor him so that "he will never have to learn that particular fact again." The teacher who does this is not thinking of what he is doing. He is merely trying with his eyes shut to make a reputation for being "thorough." Such a teacher pays no attention whatever to the way in which we naturally learn all those things in childhood that we never, never forget. A child never learns anything thoroughly the "first time;" neither does an adult. But he comes back to it again and again as he needs it; its function becomes all the while clearer and clearer, and finally we have the astonishing result that neither the worries of active life, nor the ravages of disease nor length of years, can efface the picture from memory. It is probably not without the deepest significance that teachers would do well to heed that, when in old age all the experiences of an entire middle life fade, there remain those vivid memories of childhood that were garnered up in nature's own deliberate way. In the delight of those visions of a long-ago youth, it is doubtful if the multiplication table or the division of fractions ever plays an important part. The pupil should not be belabored into mathematical processes any more than he should be belabored into words in his reading. In the latter subject the principles of the kindergarten are beginning to be appreciated; in the former, the methods of the penitentiary still prevail. 


\section{CHAPTER VI.}

\section{NATURE-STUDY AND MORALS.}

THE questions which relate to material and method in naturestudy are beginning to be treated with great intelligence and skill. It is a serious mistake to suppose, however, that when all such problems are solved we shall find the subject on its final and highest educational footing. The teacher until now has been concerned chiefly with matters of expediency and of lesser importance. $\mathrm{He}$ has but barely reached the point where a discussion of the fundamental question is possible. I refer to its place in the training for moral character. In spite of the tremendous impetus from the practical side which nature-study has received within the past decade, its position in the schools is still tentative, and its final mission in education is still problematical. It might be said, better, that its position is tentative because its mission is problematical. In these days there is a decided tendency to measure the value of any subject by the direct contribution which it is able to make to the development of character. In answer to this question, "What can nature-study do to make the pupil more upright, and more moral generally?" the teachers have not been specific; they have been hesitating, equivocal, indirect, and quite unsatisfactory. As compared with the teachers of the so-called humanities, in their answer to this great question which is the final one in education, the teachers of nature-study have not appeared to the best advantage. The former are always ready to point out that, since the materials for their subjects are drawn directly from the interrelations of men, the results of such teaching will therefore bear directly upon those mutual relations. The claim is commonly made that it is only through this direct study of human relations that moral standards become known, established, and enforced. There is scarcely any dealing between man and man that cannot be seized upon by the shrewd teacher of the humanities as proper material from which to derive a legitimate lesson that will tend to elevate and more clearly define the moral status of the human being. But when the teacher of nature-study is called upon to show an 
equivalent value in the studies that he requires his pupils to make of the tree, of the grasshopper, of the snake, of the crayfish, or of all of them together, he is not so ready with an answer. I have frequently made some interesting tests with my pupils which indicate that this indefiniteness of purpose, or possibly a lowered purpose, in teaching has its effect upon them. When they are asked for specific instances of lessons that they feel have made distinct and direct contributions to their character, they almost invariably cite examples that fall within the humanities. They say that this or that lesson has made them distinctly stronger. It has made them more certain of themselves in times of temptation than they otherwise likely would have been; that the withdrawal of such lessons from their fund of experience would be to them a real and specific loss. On the other hand, it is rare to find any student who has had high-school science who will attach anything like the same value to the lessons he has had upon the grasshopper, the earthworm, the beetle, the dandelion, or the oak tree. They are generally ready to say, still further, that, so far as they can see, these lessons might be blotted out from their experience without affecting in the least their status as moral beings.

I certainly have no desire to overstate the case, but I am decidedly of the opinion that we have here the real reason why science has such a tremendous struggle to maintain itself in the curriculum. It matters not how ignorant the teacher may be, he generally has, at least, vague notions that it is his chief business to turn out people of good moral character. He therefore devotes whatever energy and skill he may possess to the presentation of those subjects which, as he has been taught, lead to that end, and everything else is left to become the incident, or rather the accident, of the curriculum.

That we may see what has brought this state of things to pass, it is only necessary to enumerate briefly the stock reasons that are usually given for the teaching of science. In the pre-evolutionary period, all things in nature were considered almost entirely as having a peculiar relation to man. They were classified broadly into the useful and the useless. In the former there was always a strong selfish interest ; toward the latter there were feelings of indifference, if not positive hostility.

With the advent of Darwin's Origin of Species, a new interest was aroused that, for the popular mind, was derived chiefly from 
those novelties of animal and plant life which this book so strikingly portrays. It is quite probable that most teachers even today depend more upon the novelties of nature as a means of interesting their pupils in their subject than upon any other one means.

Still further, it is claimed that a great mission of science is to train the pupil in the art of seeing - that its distinct mission is to minister to the senses. That the work in science came into prominence at a time when such training was bitterly needed no one will deny, and neither will anyone claim that its value in sense-training has been overestimated.

It is urged, too, that the constant dealing with the realities of nature tend to beget an accuracy in statement, and in all forms of expression, that is directly conducive to a high moral tone. This reason is probabiy the corner-stone upon which, so far, the claims of science to moral training have chiefly rested.

The reason for the study of science, however, that has made the strongest appeal is probably found in its bearing upon the practical and economic affairs of life. Its enormous influence for good in all that we prize in material affairs is apparent to the dullest mind. The rapid development of technical schools within a generation is the strongest possible evidence as to a sincere belief in the value of a scientific education.

Finally, it is often said that nature is the embodiment of truth; that in studying science we are dealing with the eternal verities, and the effect of this must necessarily be intrinsically moral.

It is interesting to inquire whether these reasons just enumerated either separately or taken together are sufficient to give science a standing in the curriculum on as high moral grounds as that which is supposed to be occupied by the so-called humanities. While each of the reasons given may make it apparent that science is a valuable and even necessary study, it will be seen that they may be explained as mere incidents in the situation. It is no longer possible to present nature to our pupils in the two classes, the useful and the useless, because these are now known to be but relative terms, and they express but accidental relations rather than those belonging to a great design. Thus the amiability and strength of the horse are the accidents of creation which made him useful. These characteristics were developed under influences that are not wholly understood, and it has happened that man has for a time 
availed himself of the advantages offered by these qualities. But it is conceivable that the development of the automobile and its successors may seriously disturb, if not entirely change, the relationship that has heretofore existed between man and the horse. Similarly, the housefly is worse than useless; it is injurious in its habit of feeding, which makes it a carrier of disease. But the ultimate solution of this difficulty will likely be through the discovery of some means of destroying the disease germ rather than in the utter destruction of all the flies. If the germs can be controlled, the flies will become harmless. It is evident, therefore, that the study of man and the other forms of life must be done in the light of some other relationship of a more fundamental character. No one will claim that the study of nature as a novelty can ever do more than afford entertainment for a passing hour. Nor is the training of the senses an ultimate reason. For, as it has been stated already, we do not study nature so much because we wish to train the senses as we do because we wish the senses to train the man. In this function, other things not usually classed as natural objects may play an important part.

As to the clainis for a training in accuracy that comes with dealing with the realities of nature, it may be said that in this the demands of science are not unique. Accuracy is required in all the relations of life, and its importance is far more evident in the dealings between man and man than it is in the enumeration of the legs of a beetle. If the claims of science are to rest upon practical grounds, then what is to be said of the study of the thousand and one things in nature that interest the children, and older students too, which cannot by any stretch of the imagination be ranked with the so-called practical aspects of our lives? And, lastly, if we assert that nature is an eternal verity worthy in itself of study, are we not assuming the proposition which it might be conceived to be the business of science to prove?

If I have not misstated nor overstated the case, we find ourselves confronted with a difficult problem in education toward the solution of which but little has been done. It is evident, too, that until some common ground is reached upon which the two great divisions of learning, the humanities and science, may stand, we shall always find the parts of our curriculum at cross-purposes. If we are to unravel the difficulties of the situation, we must begin 
with the fundamental point from which the humanities and science have diverged. Having arrived at this, we may be able to determine whether the divergence is necessary, and to what limits it should extend.

In the first place, it must be remembered that it was the function of all education in early times to teach dogmas which were usually sunimed up in the form of a creed. This was equally true of both the humanities and science. "The heavens declare the glory of God, and the firmament showeth his handiwork," expressed the essence of a creed which for centuries held the scientific thought of the world as in the grip of a vise. In its relation to science this creed was no less exacting than the dogma set up by the humanities in regard to "the chief end of man." Modern science, however, through its slow development, gradually drew away from this creed-bound condition, and with the advent of Darwinism it suddenly broke all the bonds that remained. Then, practically, for almost the first time, men began to investigate nature with an open mind. They began to hunt for the facts unbiased by prejudice or by traditions, and utterly regardless of results. The world has never expressed even a tithe of the debt which it owes to these bold pioneers in true scientific thought and method. With almost reckless abandon they turned their backs upon all creeds and all philosophies and said: "We will know the facts. No matter whether they teach rightly or wrongly, or whether they teach anything at all, we will have the facts." This independent attitude of mind was absolutely necessary that solid foundations for natural science should be laid. It was an attitude so entirely different from what had ever been assumed before by the students of nature that it is no wonder it was misunderstood. Throughout the past, the so-called facts of science had been marshaled to prove the preconceived notions of men; not only their notions regarding their relations to each other, but also to those regarding the mission and destiny of things in general and of man in particular. It is easy to understand how these scientists, divesting themselves of every ulterior purpose in the investigation of the facts of nature, should give rise to the widespread impression that they believed, therefore, that the facts themselves were without moral significance in the lives of men. From that day forth science has seemed like a purposeless study, except so far as it may incidentally minister to 
our material wants. It is no wonder that the apparent indifferentism of science should seem cold and heartless in contrast with the sympathies of philosophy and the consolations of religion which watched every step of man's life through all its vicissitudes from the cradle to the grave, and even beyond. Teachers of science have been trained to take every precaution to prevent their pupils from bringing to their studies a preconceived notion. But we should remember that the preconceived notion is dangerous and obstructive in the search for truth only when it assumes the obstinacy of a prejudice. The preconceived notion as a tentative hypothesis is absolutely necessary to intelligent scientific research. The world for centuries was so anxious to identify the significance of the facts of nature with some selfish interest in human life that accuracy of observation became a secondary matter, and finally observation itself seemed even not to be necessary. As a reaction against this, most teachers of science have gone to the other extreme of attaching no importance whatever to the moral significance of these facts in the lives of the pupils. In many instances, no doubt, the pupils get the impression that there is no moral significance to be looked for; and so a large part of science-work remains vague and purposeless in their consciousness. I should be the last to reimpose upon science the task of supporting dogmas in morals or religion. I should like at this point, however, to raise the qucstion distinctly as to whether it is not advisable to lay more emphasis, relatively, upon a rational interpretation of the facts of nature in terms of human life and character. It seems to me to be true that a study of the moral significance of the facts in their relation to human life is as much the subject for scientific research as the facts are themselves. Indeed, to go still farther, this relationship is itself a part of the fact that is studied, and no more to be parted from it than the color is to be separated from the rose. It is evident that these facts either have a significance in the upbuilding of character, or they have not. If they have, then the pupil has a right to be taught what it is, or at least how to search for it. If they have no such significance, then it is difficult to see why they should be studied at all. Even if the study of science is pursued only for the sake of the white light of truth which it is supposed to contain, such study ever must find its ultimate justification in the effect it has upon human character, good or bad; and the pupil should be so taught as to keep this end clearly in view. 
In the endeavor to work out the moral bearings of scienceteaching, we should be careful not to employ the utterly unscientific methods of those who teach the humanities. If there is anyone who would like to support the proposition that the humanities understand how to teach morality, I should like to have him explain why it is, after centuries of effort in which they have had it all their own way, it happens that we have so much corruption, vice, and dishonesty in public, in social, and in private life. And, in these latter days, if there are any signs of quickening of the human conscience, may it not be true that it is in part due to the enlightening moral influence of scientific knowledge? I believe that morals in the past have been badly taught, because the lessons have been enforced either through a warning to flee from the wrath to come or through an exhortation to imitate some illustrious example. The moral forms may be established through fear or through imitation, but morality itself is a deeper matter. The fact that somebody else is scared into certain forms of action, called moral, by the idea of future punishment is no good reason why I, too, should be scared into the same forms. Neither is there in the simple fact that George Washington would not prevaricate any real reason why I should not lie like a pirate if I wish to do so. I believe that the exceedingly shallow and primitive methods mostly employed in teaching morals belong as far back at least as the age of the stone hatchet.

It is now the privilege of science to place the teaching of morals upon as solid ground as that upon which science itself rests. It appears to me that moral relations among men represent or express nothing more nor less than the highest known adaptations among living creatures. The final lesson of science, its very last words, are concession and adaptation. In the whole gamut of life, whether we study the microscopic motes that throng the waters, or the awkward crab that fiddles his way over the sands of the beach, or the insect buzzing in the grass, or the grass itself, or the trees, or the birds in the branches, or the tender heart that proffers the cup of cold water to the thirsty wayfarer, or the glorified soul that at once sacrifices and saves itself for the weak and unfortunate - it is still a question of concession and adaptation. To recognize and abide by this fact means development and life-physical, mental, and moral; failure to do so means degradation and death - annihila- 
tion. This lesson is taught as plainly and forcefully by the grasshopper, the mosquito, and the roadside weed as by the life of man. This is the ground of the new morality, which, supported by modern science, will furnish the ethical code for the twentieth century.

The supreme test for the value of nature-study is now at hand. For years teachers all over this country have bravely struggled to get the children in touch with nature. Books have been written by the score suggesting endless ways by which this may be done, and detailing devices to make the study interesting and pleasant; and substantial ground has been gained. During this time many burdens have been lifted from the pupils, and the teacher's work has been greatly improved. But the period of diversion is approaching an end. Not that the study of nature is to be less pleasant and interesting, but its purpose is to be more serious, more definite, more manifest.

The task now set for the friends of nature-study is great. It is not without deep-seated result that for centuries mankind has been taught that the world and the flesh have been the joint partners of the evil one. That nature-study can be a positive stimulus to the moral nature of man is a proposition resisted by the prejudices deeprooted in the ignorance and bigotry of two thousand years. From the standpoint of moral development, man at first feared nature as something that was bent upon his eternal ruin; then he despised nature as a stifling incubus upon his spiritual life. Today he regards nature as neutral and her teachings as irrelevant. This false view has given rise to an equally false and utterly misleading classification of studies in our curriculum, namely, the humanistic and scientific. We may study man and the tree; but we must study man. This partial view must always give undue precedence to the so-called humanistic, to the corresponding detriment of the so-called scientific; whereas in the not distant future we shall find through the study of nature a proper evaluation of the so-called humanistic studies. It will be according to new standards of morality set up by a study of nature, that the true worth of all studies will be determined. When this is done, all studies will be humanistic. As long as the ancient, but now almost obsolete, dualistic conception of man's nature prevailed; as long as man the spiritual being was set over against man the carnal being, so long has the house been divided against itself. But through the study of nature-of life, 
in the last analysis, human life, and its conditions - from that tiny speck, that, somehow, came into being in some sequestered spot, in a mysterious way, countless ages ago, down to the magnificent functions of a great brain that in its sympathy embraces the world, we are slowly getting rid of our primitive conception of a divided man. When at last our study shall no longer be man and nature, but man in nature, then for the first time shall we be able properly to marshal its facts as the natural means of developing the highest moral life. 


\section{APPENDIX A.}

\section{A RECORD IN NATURE-STUDY.}

\section{EXPLANATION OF FIG. 7 .}

THE three charts above the landscapes record graphically the observations of certain meteorological phenomena for April, May, and June. The narrow vertical strips are eighteen inches long and represent (arbitrarily) the day of twenty-four hours. Upon the lower part of the strips (blue on the chart) is measured off the correct proportion to represent the length of night. What remains above (yellow on the chart) represents the daylight. Upon the latter the cloudy days and the rainy days are represented respectively by the lighter and darker shades of gray. The straight horizontal line represents the freezingpoint. Above and below this, at either end, the edge of the card is graduated as a thermometer. The upper zigzag line shows the curve of mean temperature, and the lower one shows the barometric curve, the card at one side being scaled as a barometer.

Between the two lines, arrows are placed which indicate the direction of the wind. Various relationships are easily worked out. The wind that oftenest accompanies clouds, rain, or sunshine; the combination of events that accompanies the low or the high temperatures; the rise and fall of the barometer, and the rise and fall of temperature; the relation of both these curves to cloudiness and rainfall; the gradual change in the length of day and night, absolute and relative; the bearing of all combined upon the landscape pictured below - these and many other comparisons may be made at a glance, and all reveal the close interdependence of the phenomena of nature.

Above these charts, by means of the skiameter, the relative distribution of sunshine for the latitude of Chicago is shown for each month. Since the intensity varies with the distribution, and the ratio of the April rectangle is to that of June as 15 to 12 , it follows that the intensity of the latter month is one and a fourth times the intensity of the former. In other words, the sunshine that does duty on a fifteen-acre field in April will cover only about twelve acres in June.

At the left of the chart, three drawings show the slant of the sun's rays for each of the three months, and also the area that each beam covers.

The Mason jars below the landscape illustrate graphically the rainfall. Each jar contains the quantity of water that fell in a month on an area of twenty-four square inches, January being on the left. The upper row shows the average for each month during a period of thirty years. The lower row shows the rainfall by months for the year 190I. The upper row shows what 


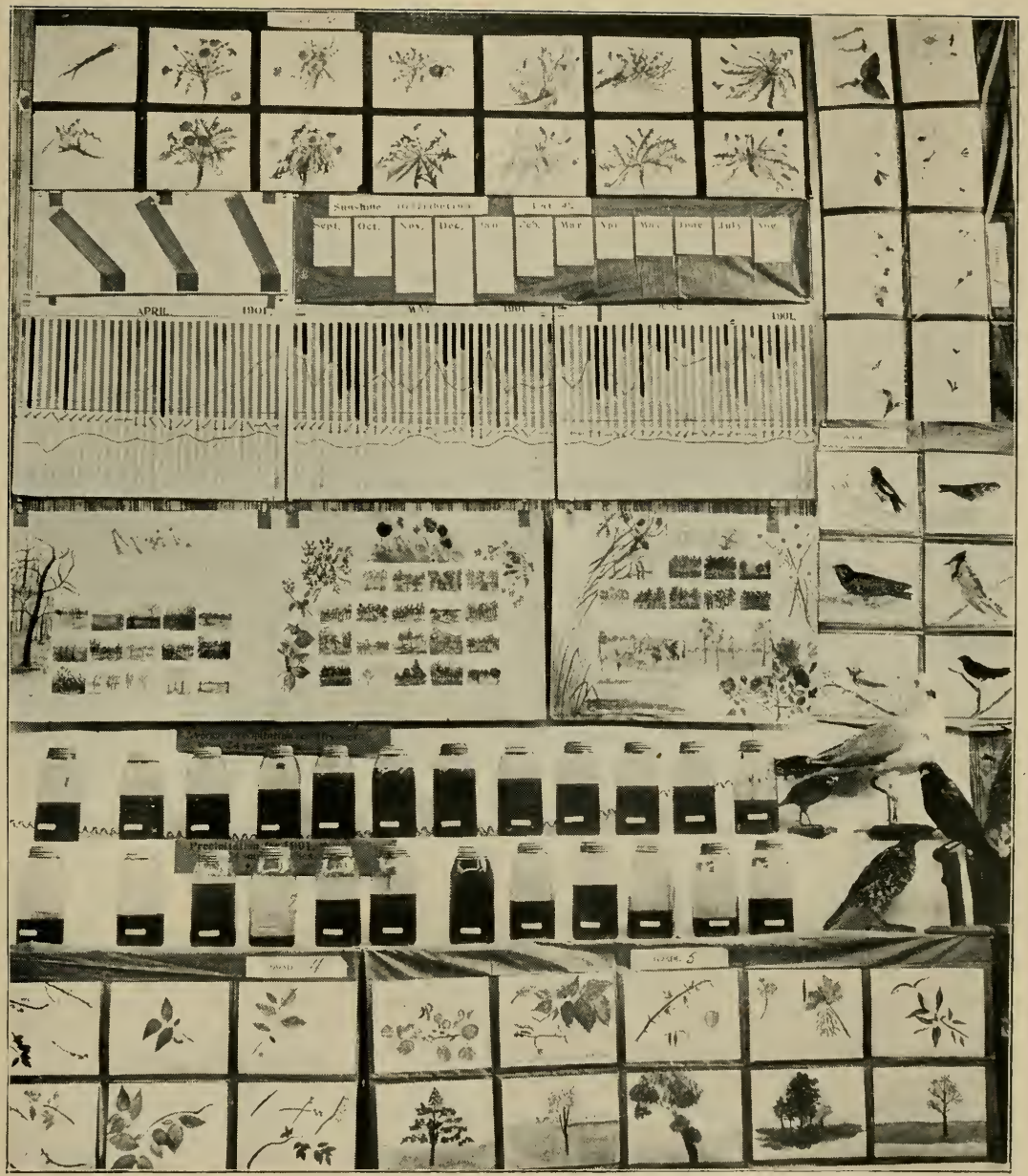

Fig. 7.-A Record in Nature-Study. 

nature promises; the lower one shows how she performs - at least how she did in I90I. During the growing season, the months are marked by important events - as, for example, germination of seeds, opening of buds, flowering, insect-development, ripening of fruit. The variation in the rainfall from the average, as told by the jars, shows how the plant and animal world, ourselves included, is subjected to great strains. It gives a striking meaning to the phrase "struggle for existence."

In the upper right-hand corner the story of the seedlings for these months is told by some plants selected from the garden. At the upper side a series of paintings shows the chapters of the dandelion's history, which represents a large number of plants that spring from roots which have survived the winter. At the bottom, the unfolding of the buds, the story of how the plant makes friends with the sunshine during these months, is told in a similar way. On the right, a few of the birds and the opossum give something of completeness to the season's pictures.

Associated with the observations of the development of plant life are records of the temperature, not only of the air, but also of the soil at different depths and of the water in the ponds. By these means the really complex nature of the environment of the living thing comes to be better understood, and the sensitiveness and plastic character of the organism grow to be more thoroughly appreciated. 


\section{APPENDIX B.}

\section{COURSE OF STUDY.}

IT is practically impossible to prepare in detail a schedule of work in nature-study that will have much value beyond that of suggestion. The aspects of nature vary greatly, and the subject-matter selected for the curriculum must vary in a way that corresponds.

The following outlines, selected from a year's work given in the author's Nature Study and Related Subjects, are submitted with a view to indicating certain typical selections of subject-matter based largely upon seasonal conditions, and also the relations of other subjects to nature-study. It must be understood that this is not an attempt to make nature-study the organizing center of the curriculum; it merely tries to show some of the things which the pupil will be interested in, most likely, and it offers suggestions as to how some other subjects may be used to assist in the development of the naturepicture. Three months, September, January, and June, representing the extremes of seasonal conditions are presented. These charts and the remaining ones for the year are described in detail in the author's book above noted.

References for September.-(Numbers correspond to those found in the charts, Appendix B.) (1) Population of an Old Pear Tree (Macmillan) ; (2) Readings in Nature's Story Book (American Book Co.) ; (3) Living Creatures of Land, Water, and Air (American Book Co.) ; (4) Flyers, Creepers and Swimmers (American Book Co.); (5) This Continent of Ours, King; (6) Entertainments in Chemistry (Interstate Publishing Co.); ( $z$ ) World of Matter (D. C. Heath \& Co.) ; (8) Normal Course in Reading (Silver, Burdett \& Co.).

References for January.-(I) Seaside and Wayside, No. 4 (Heath \& Co.) ; (2) Seaside and Wayside, No. 3 ; (3) Readings in Nature's Story Book (American Book Co.) ; (4) Normal Course in Reading; (5) Hooker's Child's Book of Nature (American Book Co.) ; (6) Story of our Continent (Ginn \& Co.) ; (7) Storyland of the Stars, Pratt; (8) Stories Mother Nature Told Her Children (Lee \& Shepard); (9) First Book in Geology (Heath \& Co.); (10) Monteith's Science Readers; (11) King's Geographical Reader, No. 2 (Lee \& Shepard) ; (12) Common Minerals and Rocks (Heath \& Co.); (I3) Leaves and Flowers (American Book Co.); (14) Fairyland of Science (Appleton); (15) Heart of Oak, Book I (Heath \& Co.) ; (I6) Heroes of Science; Botany, Geology, Zoölogy (E. \& J. B. Young \& Co., New York); (I7) Normal Course in Reading; (18) Pioneers of Science, Lodge. On Foods: Human Body, Martin (Holt \& Co.) ; Chemistry of Cooking and Cleaning, Richards (Estes \& Lauriat). 
SEPTEMBER.

THOUGHT WORK.

\begin{tabular}{|c|c|c|c|c|c|c|}
\hline \multirow[b]{2}{*}{ 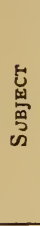 } & घू. & ZoöLOGY & \multirow{2}{*}{ 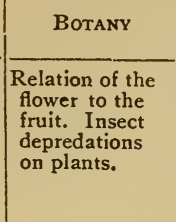 } & \multirow{2}{*}{$\frac{\text { GEOGRAPHY }}{\begin{array}{l}\text { Distribution of } \\
\text { fruits. }\end{array}}$} & \multirow{2}{*}{$\begin{array}{l}\text { Physics } \\
\text { The spectrum. } \\
\begin{array}{l}\text { Use of the } \\
\text { prism. Use } \\
\text { of compass. }\end{array}\end{array}$} & \multirow{2}{*}{$\begin{array}{l}\text { Cинмistry } \\
\text { Chemical } \\
\text { change illus- } \\
\text { trated in find- } \\
\text { ing the ash in } \\
\text { fruits. Chem- } \\
\text { ical properties } \\
\text { of the ash. }\end{array}$} \\
\hline & 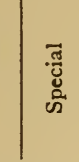 & $\begin{array}{l}\text { Insects. List of } \\
\text { birds in the neigh- } \\
\text { borhood. }\end{array}$ & & & & \\
\hline & 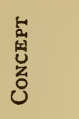 & $\begin{array}{l}\text { The adaptations of } \\
\text { animal life through } \\
\text { form and color. }\end{array}$ & $\begin{array}{l}\text { The transforma- } \\
\text { tion of parts of } \\
\text { the plant for } \\
\text { special func- } \\
\text { tions. }\end{array}$ & $\begin{array}{l}\text { Fruits.as } \\
\text { affected by } \\
\text { climate. }\end{array}$ & $\begin{array}{l}\text { Relation of } \\
\text { color to light. } \\
\text { Direction. }\end{array}$ & $\begin{array}{l}\text { The composite } \\
\text { nature of } \\
\text { fruits. }\end{array}$ \\
\hline & $\sum_{0}^{0}$ & $\begin{array}{l}\text { Insects of all kinds; } \\
\text { especially butter- } \\
\text { flies. Materials for } \\
\text { an aquarium, tad- } \\
\text { poles, fishes, craw- } \\
\text { fishes, and turtles. }\end{array}$ & $\begin{array}{l}\text { Seeds and al! } \\
\text { kinds of fruits. } \\
\text { Leaves and } \\
\text { flowers. Nuts. }\end{array}$ & $\begin{array}{l}\text { Pictures show- } \\
\text { ing fruit trees } \\
\text { of various } \\
\text { kinds, and the } \\
\text { manner of cul- } \\
\text { tivation. Also } \\
\text { the various } \\
\text { nut-bearing } \\
\text { trees. Fruits } \\
\text { and nuts. }\end{array}$ & $\begin{array}{l}\text { Leaves and } \\
\text { fruits showing } \\
\text { different } \\
\text { colors. }\end{array}$ & $\begin{array}{l}\text { The apple, } \\
\text { peach, plum, } \\
\text { pear, quince, } \\
\text { melon, squash. } \\
\text { egg-plant. }\end{array}$ \\
\hline & 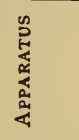 & $\begin{array}{l}\text { Drying boards for in. } \\
\text { sects. Insect nets. } \\
\text { Cyanide bottles. } \\
\text { Insect trays. Jars } \\
\text { for aquaria. Col- } \\
\text { lecting boxes. }\end{array}$ & $\begin{array}{l}\text { Boxes for pre- } \\
\text { servation of } \\
\text { seeds. }\end{array}$ & $\begin{array}{l}\text { Sandpans for } \\
\text { modeling. } \\
\text { Clay for mod- } \\
\text { eling. }\end{array}$ & $\begin{array}{l}\text { Prism, mirrors, } \\
\text { and lenses. }\end{array}$ & $\begin{array}{l}\text { Scales, Drying } \\
\text { trays, Batter- } \\
\text { sea dishes or } \\
\text { porcelain } \\
\text { crucibles. }\end{array}$ \\
\hline \multirow{2}{*}{ 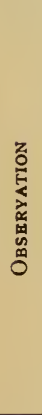 } & तี & $\begin{array}{l}\text { Flight and other } \\
\text { modes of locomo- } \\
\text { tion of insects. } \\
\text { Compare with } \\
\text { birds. Food and } \\
\text { feeding of animals. } \\
\text { Colors as related } \\
\text { to plants. }\end{array}$ & $\begin{array}{l}\text { Colors of flow- } \\
\text { ers as related } \\
\text { to the visiting } \\
\text { insects. Colors } \\
\text { of fruit-un- } \\
\text { ripe and ripe. }\end{array}$ & $\begin{array}{l}\text { Influences of po- } \\
\text { sition as seen } \\
\text { in ripening } \\
\text { fruits. Ripen- } \\
\text { ing of same } \\
\text { fruits in differ- } \\
\text { ent parts of the } \\
\text { country. }\end{array}$ & $\begin{array}{l}\text { Colors appear- } \\
\text { ing in fruits, } \\
\text { flowers, leaves, } \\
\text { and animals } \\
\text { compared with } \\
\text { spectrum. }\end{array}$ & $\begin{array}{l}\text { The decay of } \\
\text { fruits. The } \\
\text { amount of ash } \\
\text { left after burn- } \\
\text { ing wood and } \\
\text { coal. }\end{array}$ \\
\hline & 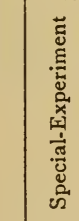 & $\begin{array}{l}\text { Organs of insects } \\
\text { for feeding and lo- } \\
\text { comotion. Struc- } \\
\text { ture of wings in } \\
\text { different insects- } \\
\text { butterfly, beetle, } \\
\text { grasshopper, fly, } \\
\text { bee. }\end{array}$ & $\begin{array}{l}\text { Parts of a fruit. } \\
\text { The modifica- } \\
\text { tions of the } \\
\text { leaf. Work of } \\
\text { insects upon } \\
\text { the leaf and } \\
\text { fruit. }\end{array}$ & $\begin{array}{l}\text { Location of } \\
\text { fruit belts. } \\
\text { Study of the } \\
\text { geographical } \\
\text { origin of culti- } \\
\text { vated fruits. }\end{array}$ & $\begin{array}{l}\text { Study of condi- } \\
\text { tions under } \\
\text { which the spec- } \\
\text { trum is formed. } \\
\text { Recomposition } \\
\text { of spectrum by } \\
\text { means of con- } \\
\text { cave mirrors } \\
\text { and convex } \\
\text { lens. }\end{array}$ & $\begin{array}{l}\text { Weigh and dry } \\
\text { definite am'nts } \\
\text { of fruits. Burn } \\
\text { definite w'ghts } \\
\text { of fruits. Ob- } \\
\text { tain amount of } \\
\text { water, dry solid } \\
\text { and ash in } \\
\text { each. }\end{array}$ \\
\hline \multicolumn{2}{|r|}{ 高 } & $\begin{array}{l}\text { A Tragedy in the } \\
\text { Grass.* (r) Mira- } \\
\text { cles of the Butter- } \\
\text { fly. (2) Muscular } \\
\text { Strength of Insects. } \\
\text { (2) Butterflies } \\
\text { and Moths. (3) }\end{array}$ & $\begin{array}{l}\text { Fruit and } \\
\text { Grain Destroy- } \\
\text { ers. (4) How } \\
\text { Plants Employ } \\
\text { Insects to } \\
\text { do their } \\
\text { Work. (2) } \\
\text { The Fruit. (2) }\end{array}$ & $\begin{array}{l}\text { Some industries } \\
\text { of Canada. (5) } \\
\text { The People of } \\
\text { Mexico. (5) } \\
\text { From St. Louis } \\
\text { to St. Paul. (5) }\end{array}$ & $\begin{array}{l}\text { "Sunbeams and } \\
\text { Their Work." } \\
\text {-Fairyland of } \\
\text { Science. } \\
\text { (Buckley.) }\end{array}$ & $\begin{array}{l}\text { The Chemistry } \\
\text { of Yeast. (6) } \\
\text { A Lesson in } \\
\text { Chemistry. (7) }\end{array}$ \\
\hline & 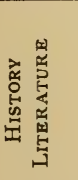 & $\begin{array}{c}\text { Grasshopper and } \\
\text { Cricket.-Leigh } \\
\text { Hunt. } \\
\text { The Humble Bee. } \\
\text { The Emerson. } \\
\text { Holydid.- } \\
\text { Holmes. }\end{array}$ & $\begin{array}{l}\text { Field Flowers. } \\
\text {-Campbell. } \\
\text { To Daisy Ele- } \\
\text { gans. -Pal. } \\
\text { mer. } \\
\text { To the Fringed } \\
\text { Gentian.- } \\
\text { Bryant. }\end{array}$ & $\begin{array}{l}\text { The Mountain } \\
\text { Monarch.- } \\
\text { Palmer. } \\
\text { The Apple.- } \\
\text { Burroughs. }\end{array}$ & $\begin{array}{l}\text { "Light," } \\
\text { Echoes of Half } \\
\text { a Century.- } \\
\text { Palmer. }\end{array}$ & $\begin{array}{l}\text { Apples in the } \\
\text { Cellar.-Hol- } \\
\text { land. }\end{array}$ \\
\hline
\end{tabular}

It seems as if that day was not wholly profane, in which we have given heed to some natural object. The fall of snowflakes in a still air preserving to each crystal its perfect form; the blowing of sleet over a wide sheet of water, and over plains, the waving ryefield, the mimic waving of acres of houstonia whose innumerable florets whiten and ripple before the eye; the reflections of trees and flowers in glassy lakes; the musical steaming odorous southwind which converts all trees into wind harps; the crackling and spurting of hemlock in the flames; or of pine logs which yield glory to the walls and faces in the sitting room - these are the music and pictures of the most ancient religion,-EMERSON, Essay on Nature. 
SEPTEMBER.

THOUGHT WORK.-Continued.

\begin{tabular}{|c|c|c|c|c|c|}
\hline \multirow{2}{*}{ 贷 } & \multirow{2}{*}{ 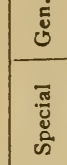 } & Meteorology & AstronOMY & Grology & \multirow{2}{*}{$\begin{array}{l}\text { Mineralogy } \\
\begin{array}{l}\text { Mechanical constit - } \\
\text { uents of soil. }\end{array}\end{array}$} \\
\hline & & $\begin{array}{l}\text { Daily record of observa- } \\
\text { tions on the weather. }\end{array}$ & $\begin{array}{l}\text { The equinox. Slant } \\
\text { of the sun's rays. }\end{array}$ & $\begin{array}{l}\text { General aspects of } \\
\text { the surrounding } \\
\text { country. }\end{array}$ & \\
\hline & 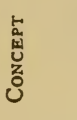 & $\begin{array}{l}\text { Relation of the weather } \\
\text { to the appearance of } \\
\text { the landscape. }\end{array}$ & $\begin{array}{l}\text { Relation of the } \\
\text { changing slant of } \\
\text { the sun's rays to } \\
\text { meteorological con- } \\
\text { ditions. }\end{array}$ & $\begin{array}{l}\text { The forces that have } \\
\text { determined the } \\
\text { present appearance } \\
\text { of the country. }\end{array}$ & $\begin{array}{l}\text { The means by which } \\
\text { rock and vegetable } \\
\text { products become } \\
\text { mixed. }\end{array}$ \\
\hline & 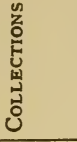 & $\begin{array}{l}\text { The maps of the Weather. } \\
\text { Bureau. }\end{array}$ & $\cdot$ & $\begin{array}{l}\text { Various rocks and } \\
\text { stones associated } \\
\text { with different kinds } \\
\text { of soils. }\end{array}$ & $\begin{array}{l}\text { Samples of soil and } \\
\text { subsoil. }\end{array}$ \\
\hline & 峁 & $\begin{array}{l}\text { Thermometer. } \\
\text { Barometer. } \\
\text { Hygrometer. } \\
\text { Wind vane }\end{array}$ & Shadow-stick. & $\begin{array}{l}\text { Boxes for speci- } \\
\text { mens. }\end{array}$ & $\begin{array}{l}\text { Sieve I- ro inch } \\
\text { mesh. Sieve I-50 } \\
\text { inch mesh. Scales. }\end{array}$ \\
\hline \multirow{2}{*}{ 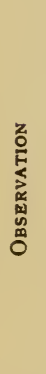 } & స్ & $\begin{array}{l}\text { Effect of temperature } \\
\text { and moisture upon } \\
\text { ripening and coloring } \\
\text { of fruits and leaves. }\end{array}$ & $\begin{array}{l}\text { Position of sun on } \\
\text { meridian and on } \\
\text { the horizon. } \\
\text { Eclipse of } \\
\text { moon. } \\
\text { Venus evening } \\
\text { star. Jupiter } \\
\text { morning star. }\end{array}$ & $\begin{array}{l}\text { Slope of land. } \\
\text { Direction of } \\
\text { streams. Kinds of } \\
\text { rock exposed. }\end{array}$ & $\begin{array}{l}\text { Soil associated with } \\
\text { best plant growth. } \\
\text { Animal life in the } \\
\text { soil. }\end{array}$ \\
\hline & 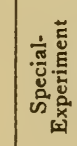 & $\begin{array}{l}\text { Find amount of rainfall; } \\
\text { relative humidity; ab- } \\
\text { solute amount of } \\
\text { moisture in atmos- } \\
\text { phere. Kinds of } \\
\text { clouds. }\end{array}$ & $\begin{array}{l}\text { Find areas covered } \\
\text { by given volume of } \\
\text { sunlight at differ- } \\
\text { ent times of the } \\
\text { month. Find angle } \\
\text { of sun's rays. }\end{array}$ & $\begin{array}{l}\text { Test the hardness } \\
\text { and solubility of } \\
\text { the country rock. }\end{array}$ & $\begin{array}{l}\text { Find coarse and fine } \\
\text { gravel and sand } \\
\text { and amount of clay } \\
\text { and loam in sam- } \\
\text { ples of soil. }\end{array}$ \\
\hline \multicolumn{2}{|c|}{ 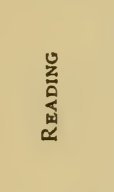 } & $\begin{array}{l}\text { Clouds. (8) The Air- } \\
\text { Breathers. (9)- } \\
\text { Kingsley. }\end{array}$ & $\begin{array}{l}\text { A Morning in } \\
\text { Moonland. (Io) } \\
\text { King Sol. (Io)- } \\
\text { Amy Johnson's } \\
\text { Sunshine. (II) } \\
\text { Looking for the } \\
\text { Sun. (r2)-Dr. } \\
\text { I. I. Hayes. }\end{array}$ & $\begin{array}{l}\text { Origin of Valleys } \\
\text { and Lakes. (13) } \\
\text { - Shaler. }\end{array}$ & $\begin{array}{l}\text { "Relation of Geol. } \\
\text { ogy to Agriculture. } \\
\text { Its Relation to } \\
\text { Health," Applied } \\
\text { Geology.- } \\
\text { Williams. } \\
\text { Soils.-Shaler. }\end{array}$ \\
\hline 离 & 㸃 & $\begin{array}{l}\text { Hymn to the Clouds.- } \\
\text { Palmer. } \\
\text { The Tempest.- } \\
\text { Dickens. }\end{array}$ & $\begin{array}{l}\text { Autumn Tides.- } \\
\text { Burroughs. } \\
\text { The Wind and the } \\
\text { Moon.-MacDon- } \\
\text { ald. }\end{array}$ & $\begin{array}{l}\text { Glaciers of the } \\
\text { Alps. Formation } \\
\text { of Glaciers. Move- } \\
\text { ment of Glaciers. }\end{array}$ & $\begin{array}{l}\text { On the Cliff.- } \\
\text { Rossiter Fohnson. }\end{array}$ \\
\hline & 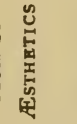 & \multicolumn{4}{|c|}{$\begin{array}{l}\text { Whatsoever is beautiful is for the same reason good, when suited to the purpose for } \\
\text { which it was intended. Whatsoever is suited for the end intended, with respect to that } \\
\text { end is good and fair; and contrariwise it must be deemed evil and deformed when it } \\
\text { departs from the purpose which it was designed to promote. - Socrates. }\end{array}$} \\
\hline
\end{tabular}


SEPTEMBER.

FORM WORK.

\begin{tabular}{|c|c|c|c|c|c|}
\hline & ZoöLOGY & Botany & GEOGRAPHY & Physics & Chemistrey \\
\hline 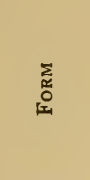 & $\begin{array}{l}\text { Geometric form of } \\
\text { the wing; propor- } \\
\text { tions of parts. } \\
\text { Meaning of the } \\
\text { form and propor- } \\
\text { tions. Form and } \\
\text { proportions of the } \\
\text { bodies of insects. }\end{array}$ & $\begin{array}{l}\text { Geometric } \\
\text { forms and pro- } \\
\text { portions in va- } \\
\text { rious fruits and } \\
\text { leaves. The } \\
\text { meaning of } \\
\text { these forms and } \\
\text { proportions. }\end{array}$ & $\begin{array}{l}\text { Relief forms in } \\
\text { continental } \\
\text { areas. }\end{array}$ & $\begin{array}{l}\text { The form of the } \\
\text { prism. Size } \\
\text { of its angles. } \\
\text { Forms of mir- } \\
\text { rors used. }\end{array}$ & \\
\hline 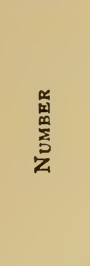 & $\begin{array}{l}\text { Prevailing colors of } \\
\text { insects. Relation } \\
\text { of insect coloration } \\
\text { to colors of flowers } \\
\text { and plants in gen- } \\
\text { eral. Varieties of } \\
\text { insects. }\end{array}$ & $\begin{array}{l}\text { Proportion of } \\
\text { leaves on dif- } \\
\text { ferent kinds of } \\
\text { trees partly } \\
\text { eaten by in- } \\
\text { sects. Fruits } \\
\text { injured by in- } \\
\text { sects. Propor- } \\
\text { tion of water } \\
\text { and dry solids } \\
\text { in different } \\
\text { kinds of fruits. }\end{array}$ & $\begin{array}{l}\text { Relative value } \\
\text { of the various } \\
\text { fruits produced } \\
\text { in the United } \\
\text { States. Rela- } \\
\text { tive production } \\
\text { in different } \\
\text { fruit regions. } \\
\text { Fall crop } \\
\text { regions. }\end{array}$ & $\begin{array}{l}\text { Primary colors. } \\
\text { Colors found } \\
\text { in fruits. In } \\
\text { the landscape. }\end{array}$ & $\begin{array}{l}\text { Proportions of } \\
\text { ash in fruits. } \\
\text { Ratio of ash to } \\
\text { dry solid; to } \\
\text { the water. }\end{array}$ \\
\hline 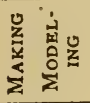 & $\begin{array}{l}\text { Forms of the bodies } \\
\text { of animals studied. } \\
\text { Drying board for } \\
\text { insects. }\end{array}$ & $\begin{array}{l}\text { Fruits and } \\
\text { leaves studied. } \\
\text { Trays for dry- } \\
\text { ing fruits. }\end{array}$ & $\begin{array}{l}\text { Maps showing } \\
\text { fruit areas. }\end{array}$ & $\begin{array}{l}\text { Make a prism } \\
\text { and mount it. } \\
\text { Make a mag- } \\
\text { netic needle. }\end{array}$ & \\
\hline 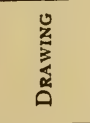 & $\begin{array}{l}\text { Show structure of } \\
\text { insect as a whole } \\
\text { and in its parts: } \\
\text { e. g., wing, foot, } \\
\text { leg, mouth. }\end{array}$ & $\begin{array}{l}\text { Fruits and } \\
\text { leaves. Fruits } \\
\text { in various sec- } \\
\text { tions to show } \\
\text { structure. }\end{array}$ & $\begin{array}{l}\text { Maps showing } \\
\text { distribution of } \\
\text { fruits and } \\
\text { grains. }\end{array}$ & $\begin{array}{l}\text { Drawing of rays } \\
\text { of light in their } \\
\text { course through } \\
\text { the prism. }\end{array}$ & $\begin{array}{l}\text { Drawing of } \\
\text { apparatus. }\end{array}$ \\
\hline نั & $\begin{array}{l}\text { Animals conspic- } \\
\text { uous by color. } \\
\text { Show adaptation of } \\
\text { color. }\end{array}$ & $\begin{array}{l}\text { Flowers, fruits } \\
\text { and leaves. } \\
\text { Landscape } \\
\text { effects prod'c'd } \\
\text { by plants. }\end{array}$ & $\begin{array}{l}\text { Landscape } \\
\text { colors. }\end{array}$ & The spectrum. & \\
\hline$\sum_{z=0}^{0}$ & $\begin{array}{l}\text { How animals hide } \\
\text { themselves. How } \\
\text { animals move- } \\
\text { walking, flying. } \\
\text { How insect flight } \\
\text { differs from that of } \\
\text { birds. }\end{array}$ & $\begin{array}{l}\text { How different } \\
\text { fruits are } \\
\text { formed. How } \\
\text { insects use } \\
\text { leaves and } \\
\text { stems. }\end{array}$ & $\begin{array}{l}\text { Preparation and } \\
\text { shipment of } \\
\text { fruits to mar- } \\
\text { ket. Prepara- } \\
\text { tion of fruits } \\
\text { for food. }\end{array}$ & $\begin{array}{l}\text { The combina- } \\
\text { tions of colors } \\
\text { in a September } \\
\text { landscape. }\end{array}$ & $\begin{array}{l}\text { How to find the } \\
\text { ash in fruits. }\end{array}$ \\
\hline
\end{tabular}

Study of the language forms necessary in all written and oral expression which occurs in the study of all subjects. Choice of words; spelling; capitals ; pronunciation ; punctuation; sentence; subject and predicate; paragraph; figures of speech. Function of words - parts of speech. Relations of words.

\begin{tabular}{|c|c|c|c|c|c|}
\hline 峁 & $\begin{array}{l}\text { "Hunting Glee," } \\
\text { National Music } \\
\text { Reader No. 4. }\end{array}$ & $\begin{array}{l}\text { "The Hunter } \\
\text { and the Wild } \\
\text { Rose," Na- } \\
\text { tional Music } \\
\text { Reader No. 4. }\end{array}$ & $\begin{array}{l}\text { "The Field and } \\
\text { the Wood," } \\
\text { National } \\
\text { Music } \\
\text { Reader No. 4. }\end{array}$ & {$\left[\begin{array}{l}\text { "Autumn," } \\
\text { National } \\
\text { Music } \\
\text { Reader No. 4. }\end{array}\right.$} & $\begin{array}{l}\text { "The Sad } \\
\text { Leaves are } \\
\text { Dying," Public } \\
\text { School Music } \\
\text { Course No. } 5 \text {. }\end{array}$ \\
\hline 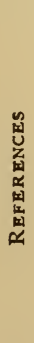 & $\begin{array}{l}\text { Birds Through an } \\
\text { Opera Glass. - } \\
\text { Meriam. } \\
\text { Home Studies in } \\
\text { Nature.-Treat. } \\
\text { Fairyland of } \\
\text { Science, chap. } \\
\text { ix.-Buckley. } \\
\text { Darwinism.-Wal- } \\
\text { lace. } \\
\text { Humbolt Lib. }\end{array}$ & $\begin{array}{l}\text { How to Know } \\
\text { the Wildflow- } \\
\text { ers.-Dana. } \\
\text { Flowers, Fruits, } \\
\text { and Leaves.- } \\
\text { Lubbock. } \\
\text { Introduction to } \\
\text { Botany.- } \\
\text { Spalding. } \\
\text { Recreations in } \\
\text { Botany.- } \\
\text { Creevy. } \\
\text { Fairyland of } \\
\text { Science.- } \\
\text { Buckley, } \\
\text { chap. vii. }\end{array}$ & $\begin{array}{l}\text { Handbook of } \\
\text { Commercial } \\
\text { Geography.- } \\
\text { Chisholm. } \\
\text { Java, the Pearl } \\
\text { of the East.- } \\
\text { Higginson. }\end{array}$ & $\begin{array}{l}\text { Six Lectures on } \\
\text { Light.--Tyn- } \\
\text { dall. }\end{array}$ & $\begin{array}{l}\text { "Decay in the } \\
\text { Apple Barrel," } \\
\text { Popular } \\
\text { Science } \\
\text { Monthly, May, } \\
\text { Igo3. } \\
\text { Remsen's Chem- } \\
\text { istry. Cooke's } \\
\text { Laboratory } \\
\text { Practice. First } \\
\text { Book on Chem- } \\
\text { istry. Shazw- } \\
\text { Brewster. }\end{array}$ \\
\hline
\end{tabular}


SEPTEMBER.

FORM WORK.-Continued.

\begin{tabular}{|c|c|c|c|c|}
\hline & METEOROLOGY & Astronomy & Geology & MineRALOGY \\
\hline 龒 & $\begin{array}{l}\text { Cloud forms at different } \\
\text { times of the day. }\end{array}$ & $\begin{array}{l}\text { Varying form of } \\
\text { the moon. Size } \\
\text { and variation of } \\
\text { the angle of the } \\
\text { sun's rays. }\end{array}$ & Relief forms & $\begin{array}{l}\text { Forms of weathered } \\
\text { minerals and } \\
\text { rocks. Meaning } \\
\text { of the forms. }\end{array}$ \\
\hline$\sum_{\text {Z }}^{\text {幽 }}$ & $\begin{array}{l}\text { Compare the rainfall by } \\
\text { weeks. Ratio to the } \\
\text { annual rainfall. } \\
\text { Amount of water to an } \\
\text { acre. Humidity of the } \\
\text { atmosphere. }\end{array}$ & $\begin{array}{l}\text { Ratio of length of } \\
\text { day to that of the } \\
\text { night. Rate of } \\
\text { change in day's } \\
\text { length during the } \\
\text { month. Variation } \\
\text { in size of angle of } \\
\text { noon rays. }\end{array}$ & $\begin{array}{l}\text { Comparison of va- } \\
\text { rious areas having } \\
\text { natural boundaries } \\
\text { in the neighbor- } \\
\text { hood. }\end{array}$ & $\begin{array}{l}\text { Proportion of sand, } \\
\text { gravel and clay in } \\
\text { soil studied. }\end{array}$ \\
\hline 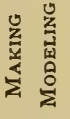 & $\begin{array}{l}\text { Make a hygrometer. } \\
\text { Rain-guage. Baro- } \\
\text { meter. }\end{array}$ & $\begin{array}{l}\text { Make a shadow- } \\
\text { stick. }\end{array}$ & $\begin{array}{l}\text { Make boxes and } \\
\text { trays for speci- } \\
\text { mens. }\end{array}$ & $\begin{array}{l}\text { Make sieves for } \\
\text { analyzing soils. }\end{array}$ \\
\hline 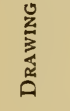 & $\begin{array}{l}\text { Drawing of cloud forms. } \\
\text { Of instruments to be } \\
\text { used in making. }\end{array}$ & $\begin{array}{l}\text { Varying angle of } \\
\text { noon rays of sun. } \\
\text { Moon's phases. }\end{array}$ & $\begin{array}{l}\text { Various natural } \\
\text { areas studied. }\end{array}$ & \\
\hline 昶 & $\begin{array}{l}\text { Cloud effects in color at } \\
\text { different times during } \\
\text { the day. }\end{array}$ & Sky colors. & $\begin{array}{l}\text { Landscape effects } \\
\text { produced by soil } \\
\text { and rock. }\end{array}$ & $\begin{array}{l}\text { Landscape effects } \\
\text { produced by soils. }\end{array}$ \\
\hline 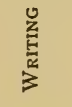 & $\begin{array}{l}\text { Compare the meteoro- } \\
\text { logical conditions of } \\
\text { September at Chicago } \\
\text { with other regions. }\end{array}$ & $\begin{array}{l}\text { How the moon } \\
\text { changes in one } \\
\text { month. }\end{array}$ & $\begin{array}{l}\text { How soil is made } \\
\text { from rock. }\end{array}$ & $\begin{array}{l}\text { How soils are } \\
\text { mingled. }\end{array}$ \\
\hline
\end{tabular}

Study of the language forms necessary in all written and oral expression which occurs in the study of all subjects. Choice of words; spelling; capitals ; pronunciation; punctuation; sentence: subject and predicate; paragraph; figures of speech. Function of words - parts of speech. Relations of words.

\begin{tabular}{|c|c|c|c|c|}
\hline$\underset{5}{5}$ & $\begin{array}{l}\text { "When Comes Re- } \\
\text { freshing Rain," Na- } \\
\text { tional Music Reader } \\
\text { No. 4. }\end{array}$ & $\begin{array}{l}\text { "Song of the } \\
\text { Stars," National } \\
\text { Music Reader } \\
\text { No. 4. }\end{array}$ & $\begin{array}{l}\text { "The Mountain- } \\
\text { eer's Song," } \\
\text { Public School } \\
\text { Music Course } \\
\text { No.6. }\end{array}$ & $\begin{array}{l}\text { "Nutting Song," } \\
\text { Public School } \\
\text { Music Course } \\
\text { No. 6. }\end{array}$ \\
\hline 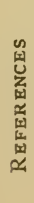 & $\begin{array}{l}\text { Elementary Meteor- } \\
\text { ology.-Davis. } \\
\text { Instructions to Volun- } \\
\text { tary Observers, U. } \\
\text { S. Weather Bureau. } \\
\text { Fairyland of Science, } \\
\text { chap. iv. - Buckley. } \\
\text { Forms of Water.-Tyn- } \\
\text { dall. }\end{array}$ & $\begin{array}{l}\text { Teacher's Manual } \\
\text { of Geography.- } \\
\text { Redway. } \\
\text { Starland.-Ball. } \\
\text { Astronomy.-New- } \\
\text { comb. Briefer } \\
\text { Course. }\end{array}$ & $\begin{array}{l}\text { Shall We Teach } \\
\text { Geology.- } \\
\text { Winchell. } \\
\text { Geological Story.- } \\
\text {-Dana. } \\
\text { Aspects of the } \\
\text { Earth.-Shaler. }\end{array}$ & $\begin{array}{l}\text { Common Minerals } \\
\text { and Rocks.- } \\
\text { Crosby. } \\
\text { Crosby's Tables. }\end{array}$ \\
\hline
\end{tabular}


JANUARY.

THOUGHT WORK.

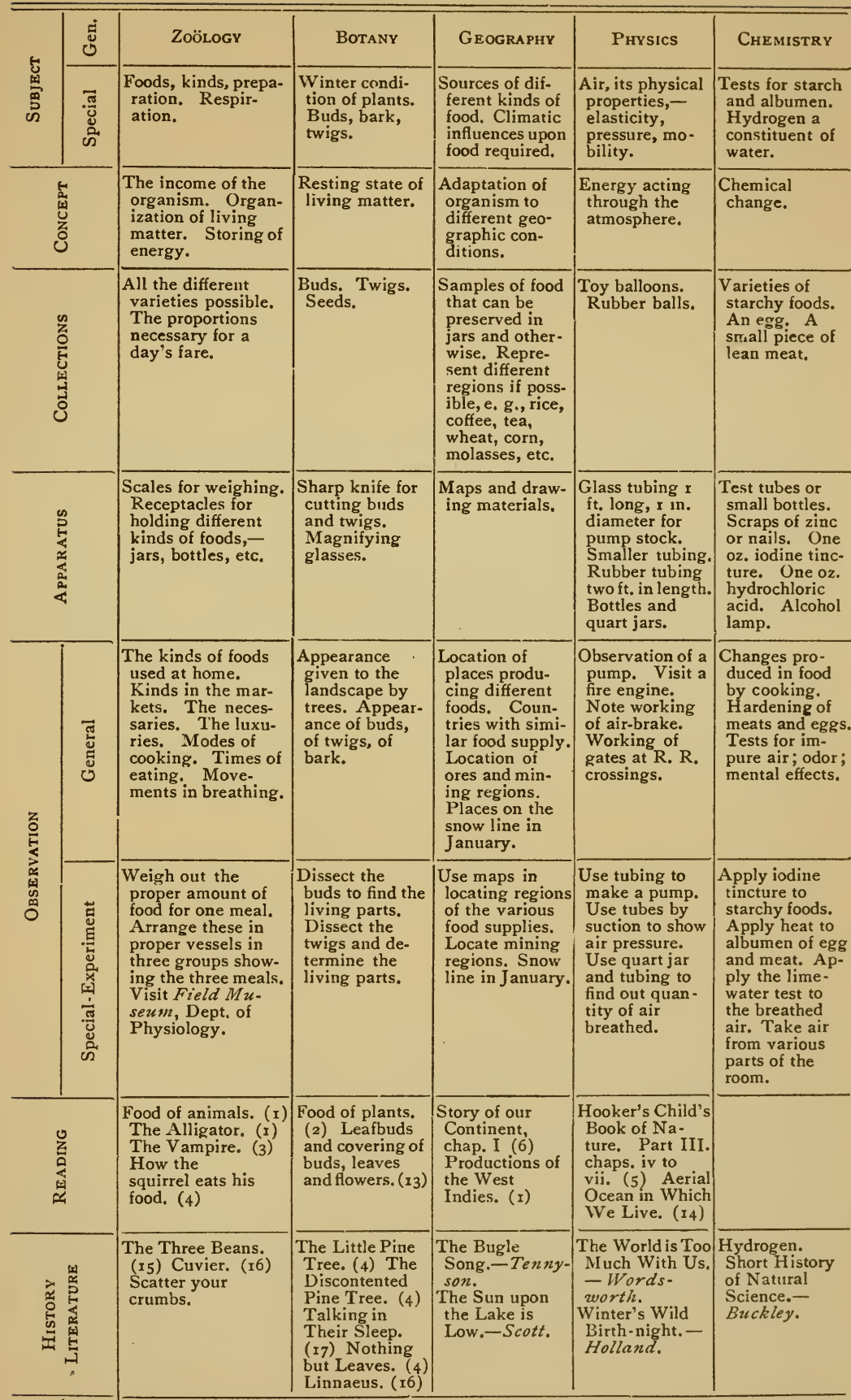

The true object of science is to lead the mind of man towards its noble destinationa knowledge of truth-to spread sound and useful ideas among the lowest classes of people, to draw human beings from the effects of prejudices and passions, to make reason the arbitrator and supreme guide of public opinion.-Cuvier, Heroes of Science. 
JANUARY.

THOUGHT WORK-Continued.

\begin{tabular}{|c|c|c|c|c|c|}
\hline \multirow{2}{*}{ 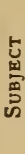 } & ड્ & METEOROLOGY & Astronomy & Geology & Mineralogy \\
\hline & 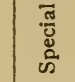 & $\begin{array}{l}\text { Effects of weather upon } \\
\text { demand for food. Ef- } \\
\text { fects upon productions. }\end{array}$ & $\begin{array}{l}\text { Effect of season } \\
\text { changes upon food } \\
\text { required. }\end{array}$ & $\begin{array}{l}\text { Fossil plants as a } \\
\text { history of life } \\
\text { on the earth. }\end{array}$ & $\begin{array}{l}\text { Testing minerals. } \\
\text { Ores. }\end{array}$ \\
\hline \multicolumn{2}{|r|}{ 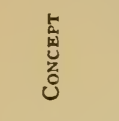 } & $\begin{array}{l}\text { Sensitiveness of the or- } \\
\text { ganism to meteorologi- } \\
\text { cal influences. }\end{array}$ & $\begin{array}{l}\text { Changing relation } \\
\text { of the earth and } \\
\text { sun. }\end{array}$ & $\begin{array}{l}\text { Persistence of life } \\
\text { upon the earth. } \\
\text { Time included in } \\
\text { life history on the } \\
\text { earth. }\end{array}$ & $\begin{array}{l}\text { Contrast between } \\
\text { the organic and the } \\
\text { inorganic. }\end{array}$ \\
\hline \multicolumn{2}{|c|}{ 总 } & & . & $\begin{array}{l}\text { Fossils that may be } \\
\text { found in lake-shore } \\
\text { pebbles or in coal } \\
\text { and slate at the } \\
\text { coal yards. }\end{array}$ & Stones. Ores. \\
\hline \multicolumn{2}{|r|}{ 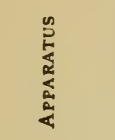 } & $\begin{array}{l}\text { Rain gauge. Barometer. } \\
\text { Thermometer. Hygro- } \\
\text { meter. Weather maps. }\end{array}$ & $\begin{array}{l}\text { Shadow-Stick. } \\
\text { Ruler. Brass Pro- } \\
\text { tractor. }\end{array}$ & $\begin{array}{l}\text { Jars for holding } \\
\text { water and sand to } \\
\text { show how leaves } \\
\text { and other forms } \\
\text { may become im- } \\
\text { bedded. }\end{array}$ & $\begin{array}{l}\text { Acid. Alcohol lamp. } \\
\text { Blowpipe. Char- } \\
\text { coal. Forceps. }\end{array}$ \\
\hline \multirow{2}{*}{ 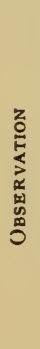 } & సँّ & $\begin{array}{l}\text { Iufluence of the weather } \\
\text { upon the appetite. In- } \\
\text { fluence upon mental } \\
\text { and physical activity. } \\
\text { Character of the rain. } \\
\text { Kinds of clouds. Forms } \\
\text { of snowflakes. Frost } \\
\text { crystals. }\end{array}$ & $\begin{array}{l}\text { Points on the hori- } \\
\text { zon of sunrise and } \\
\text { sunset. Moon's } \\
\text { phases. Venus } \\
\text { evening star. Mars } \\
\text { and Jupiter. Con- } \\
\text { stellations. }\end{array}$ & $\begin{array}{l}\text { Burial of sticks, } \\
\text { leaves and other } \\
\text { forms in mud and } \\
\text { silt. Visit coal } \\
\text { yards and quarries } \\
\text { and the lake shore } \\
\text { in search of fossils. }\end{array}$ & $\begin{array}{l}\text { Uses of metals of } \\
\text { various kinds. Iron, } \\
\text { lead, brass, copper, } \\
\text { tin, zinc in ma- } \\
\text { chines and in man- } \\
\text { ufactures. }\end{array}$ \\
\hline & 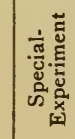 & $\begin{array}{l}\text { Measure the rainfall. } \\
\text { Depth of snow. } \\
\text { Measure the humidity } \\
\text { with hygrometer. }\end{array}$ & $\begin{array}{l}\text { Measure slant of } \\
\text { sun's rays. Note } \\
\text { length of day and } \\
\text { night. }\end{array}$ & $\begin{array}{l}\text { Into a jar of water } \\
\text { sprinkle sand or silt } \\
\text { and illustrate how } \\
\text { leaves and twigs or } \\
\text { bones may be } \\
\text { buried. }\end{array}$ & $\begin{array}{l}\text { Test the ores as to } \\
\text { solubility, fusibility, } \\
\text { hardness, etc. }\end{array}$ \\
\hline \multicolumn{2}{|r|}{ 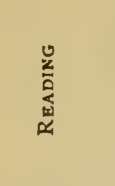 } & Clouds and Rain. (4) & $\left\{\begin{array}{l}\text { Storyland of the } \\
\text { Stars. -Pratt. (7) }\end{array}\right.$ & $\begin{array}{l}\text { Story of the Amber } \\
\text { Beads. (8) Earth } \\
\text { Building. (I) A } \\
\text { mountain of fossils. } \\
\text { Written in Rocks. } \\
\text { (x) Footprints in } \\
\text { the Sand. (I) } \\
\text { Fossils. (9) }\end{array}$ & $\begin{array}{l}\text { Mining. (10) Com- } \\
\text { mon Minerals and } \\
\text { Rocks. (12) }\end{array}$ \\
\hline \multicolumn{2}{|c|}{ 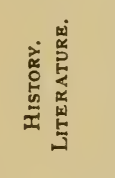 } & $\begin{array}{l}\text { Snowflakes. (2) Rime } \\
\text { of the Ancient Mariner. } \\
\text { - Coleridge. } \\
\text { The First Snow-fall.- } \\
\text { Lowell. } \\
\text { Blow Blow Thou Winter } \\
\text { Wind.-As You Like } \\
\text { It. }\end{array}$ & $\begin{array}{l}\text { What Can I Do. (2) } \\
\text { Copernicus. (18) } \\
\text { The Silver Boat. } \\
\text { (7)-M. F. Butts. } \\
\text { Hesperus' Song. - } \\
\text { Ben Jonson. }\end{array}$ & $\begin{array}{l}\text { Life of Steno. ( } 16) \\
\text { The Petrified Fern. } \\
\text { - Mary Bolles } \\
\text { Branch. }\end{array}$ & $\begin{array}{l}\text { Flint and Steel.- } \\
\text { Saxe. }\end{array}$ \\
\hline
\end{tabular}

In nature, all is useful, all is beautiful. It is therefore beautiful because it is alive, moving, reproductive; it is therefore useful because it is symmetrical and fair. Beauty will not come at the call of a legislature, nor will it repeat in England or America its history in Greece. It will come as always, unannounced, and spring up between the feet of brave and earnest men. It is in vain that we look for genius to reiterate its miracles in the old arts; it is its instinct to find beauty and holiness in new and necessary facts, in the field and roadside, in the shop and mill.-EMERSON, Essay on Art. 
JANUARY.

FORM WORK.

\begin{tabular}{|c|c|c|c|c|c|}
\hline & ZoÖLOGY & BOTANY & GeOGRAPHy & Physics & Chemistry \\
\hline 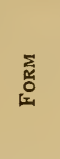 & $\begin{array}{l}\text { Forms of fruits used } \\
\text { as food as wholes } \\
\text { and in sections. }\end{array}$ & $\begin{array}{l}\text { Geometric forms } \\
\text { found in buds } \\
\text { and their sec- } \\
\text { tions. Form in } \\
\text { section of twigs } \\
\text { showing mode } \\
\text { of growth. }\end{array}$ & $\begin{array}{l}\text { Vertical and } \\
\text { horizontal } \\
\text { forms of natural } \\
\text { divisions. }\end{array}$ & $\begin{array}{l}\text { Forms occurring } \\
\text { in apparatus. } \\
\text { Circle, rect- } \\
\text { angle, cylinder. } \\
\text { Relation of } \\
\text { form to } \\
\text { function. }\end{array}$ & \\
\hline 战 & $\begin{array}{l}\text { Cost of a meal ; of } \\
\text { each article of food; } \\
\text { of a day's board; } \\
\text { board for a week, } \\
\text { month, year. Cost } \\
\text { for a family. }\end{array}$ & $\begin{array}{l}\text { Compare num- } \\
\text { ber of buds } \\
\text { frost-killed } \\
\text { with the num- } \\
\text { ber of buds still } \\
\text { alive on last } \\
\text { year's growth. }\end{array}$ & $\begin{array}{l}\text { A reas of the } \\
\text { regions produ- } \\
\text { cing different } \\
\text { foods compared. } \\
\text { Mining regions. }\end{array}$ & $\begin{array}{l}\text { A mount of air } \\
\text { breathed each } \\
\text { respiration. } \\
\text { Examples } \\
\text { showing elas- } \\
\text { ticity of air. } \\
\text { Diameters of } \\
\text { the chest in } \\
\text { various phases } \\
\text { of respiration, } \\
\text { before and after } \\
\text { exercise. }\end{array}$ & \\
\hline $\begin{array}{l}u \\
z \\
z \\
z \\
z \\
z \\
z \\
z\end{array}$ & $\begin{array}{l}\text { To show bulk of food } \\
\text { needed. Fruits } \\
\text { used as food. }\end{array}$ & $\begin{array}{l}\text { Forms of buds, } \\
\text { twigs and seeds. }\end{array}$ & $\begin{array}{l}\text { Sand modeling } \\
\text { maps. Show } \\
\text { relief of differ- } \\
\text { ent food areas. }\end{array}$ & $\begin{array}{l}\text { Make suction } \\
\text { and force } \\
\text { pumps. Siphon. } \\
\text { Form of the } \\
\text { chest; relative } \\
\text { diametors in } \\
\text { respiration. }\end{array}$ & $\begin{array}{l}\text { Apparatus for } \\
\text { for making } \\
\text { hydrogen. }\end{array}$ \\
\hline 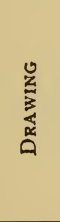 & Fruits used as food. & $\left\{\begin{array}{c}\text { Sections of buds, } \\
\text { and twigs show- } \\
\text { ing location of } \\
\text { living material. }\end{array}\right.$ & $\begin{array}{l}\text { Maps showing } \\
\text { location of food } \\
\text { producing } \\
\text { regions. Min- } \\
\text { ing regions. }\end{array}$ & $\begin{array}{l}\text { Apparatus need- } \\
\text { ed to show } \\
\text { properties of } \\
\text { air. Essentials } \\
\text { of a fire engine } \\
\text { of an air brake; } \\
\text { of R. R. cross- } \\
\text { ing gate. Pumps } \\
\text { showing valves. } \\
\text { Barometer. }\end{array}$ & $\begin{array}{l}\text { Apparatus need- } \\
\text { ed for making } \\
\text { hydrogen. }\end{array}$ \\
\hline نั & $\begin{array}{l}\text { Colors of fruits used } \\
\text { as food. }\end{array}$ & $\begin{array}{l}\text { Paint sections of } \\
\text { buds and twigs } \\
\text { to show living } \\
\text { parts. }\end{array}$ & $\begin{array}{l}\text { Landscapes. } \\
\text { Winter colors. }\end{array}$ & & $\begin{array}{l}\text { The color of } \\
\text { starch in the } \\
\text { test with iodine. }\end{array}$ \\
\hline$\underset{3}{\stackrel{U}{E}}$ & $\begin{array}{l}\text { Preparation of food. } \\
\text { Time of eating } \\
\text { with different ani- } \\
\text { mals. Flesh eaters. } \\
\text { Vegetarians, Sum. } \\
\text { mary of work. }\end{array}$ & $\begin{array}{l}\text { Winter aspects } \\
\text { of plants. The } \\
\text { woods in win- } \\
\text { ter. Summary } \\
\text { of observations. }\end{array}$ & $\begin{array}{l}\text { Foods of differ- } \\
\text { ent nations. } \\
\text { Modes of eat- } \\
\text { ing. Modes of } \\
\text { cooking. }\end{array}$ & $\begin{array}{l}\text { Description of } \\
\text { a fire engine. } \\
\text { Description of } \\
\text { an air brake. } \\
\text { Description of } \\
\text { a lifting pump. } \\
\text { Description of } \\
\text { a barometer. } \\
\text { Summary of } \\
\text { experiments. }\end{array}$ & $\begin{array}{l}\text { Hydrogen com- } \\
\text { pared with oxy- } \\
\text { gen. How } \\
\text { hydrogen is } \\
\text { prepared. }\end{array}$ \\
\hline
\end{tabular}

Study of the language forms necessary in all written and oral expression which occurs in the study of all subjects. Choice of words ; spelling ; capitals ; pronunciation ; punctuation; sentence, subject and predicate; paragraph; figures of speech. Function of words -parts of speech. Relations of words.

\begin{tabular}{|c|c|c|c|c|c|}
\hline 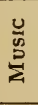 & $\begin{array}{l}\text { "Nature gives no } \\
\text { sorrow,"-Nat. } \\
\text { Mus, Course No. x. }\end{array}$ & $\begin{array}{l}\text { "EveningPrayer } \\
\text { in the Forest." } \\
- \text { Nat. Mus. } \\
\text { Course No. } 4 .\end{array}$ & $\begin{array}{l}\text { "Midwinter." - } \\
\text { Nat. Mus. } \\
\text { Course No. 2. }\end{array}$ & $\begin{array}{l}\text { "What God per- } \\
\text { forms."-Nat. } \\
\text { Mus. Course } \\
\text { No. 4. }\end{array}$ & $\begin{array}{l}\text { "Winter Song.- } \\
\text { Nat. Mus. } \\
\text { Course No. 2. }\end{array}$ \\
\hline 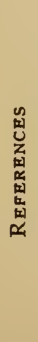 & $\begin{array}{l}\text { Life in Nature. } \\
\text { Humboldt Lib.- } \\
\text { Hinton. } \\
\text { The Study of Ani- } \\
\text { mal Life.-Thom- } \\
\text { son. } \\
\text { The Human Body.-- } \\
\text { Martin. } \\
\text { "Air and Life." } \\
\text { Smithsonian Rep. } \\
\text { '93. }\end{array}$ & $\begin{array}{l}\text { A Year with the } \\
\text { Trees.-Flagg. } \\
\text { Aspects of the } \\
\text { Earth.- } \\
\text { Shaler. }\end{array}$ & $\begin{array}{l}\text { Geographical } \\
\text { Reader.- } \\
\text { Fohonnot. } \\
\text { Geographical } \\
\text { Readers.- } \\
\text { King. } \\
\text { Aspects of the } \\
\text { Earth.- } \\
\text { Shaler. }\end{array}$ & $\begin{array}{l}\text { "Breath and } \\
\text { Breathing."'Sci. } \\
\text { for All. Vol. } \\
\text { IV. } \\
\text { Conservation of } \\
\text { Energy. Hum- } \\
\text { boldt Lib.- } \\
\text { Balfour } \\
\text { Stcwart. }\end{array}$ & $\begin{array}{l}\text { Entertainment } \\
\text { in Chemistry. } \\
\text { - Tyler. } \\
\text { Chemistry of } \\
\text { Common Life. } \\
\text { - Fohnson. } \\
\text { First Book in } \\
\text { Chemistry. } \\
\text { Shaw- } \\
\text { Brewster. } \\
\text { Foods.-Inter- } \\
\text { National Sci. } \\
\text { Series. } \\
\text { Chemistry of } \\
\text { Cooking.- } \\
\text { Williams. }\end{array}$ \\
\hline
\end{tabular}




\section{JANUARY.}

FORM WORK.-Continued.

\begin{tabular}{|c|c|c|c|c|}
\hline & METEOROLOGY & AsTRONOMY & Geology & MiNERALOGY \\
\hline 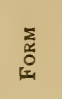 & $\begin{array}{l}\text { Cloud forms. Compare } \\
\text { with previous months. }\end{array}$ & $\begin{array}{l}\text { Angles formed by } \\
\text { slant of sun's rays. } \\
\text { Compare with pre- } \\
\text { vious months. }\end{array}$ & $\begin{array}{l}\text { Forms of fossils. } \\
\text { Ferns. }\end{array}$ & Forms of crystals. \\
\hline 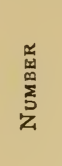 & $\begin{array}{l}\text { Averages of daily rec- } \\
\text { ords. Compare with } \\
\text { previous month. Io } \\
\text { inches snow = I inch } \\
\text { rainfall. Compare } \\
\text { rainfall and humidity } \\
\text { with previous months. }\end{array}$ & $\begin{array}{l}\text { Compare slant of } \\
\text { sun's rays and } \\
\text { day's length with } \\
\text { slant and length in } \\
\text { previous months. }\end{array}$ & $\begin{array}{l}\text { Estimated rate of } \\
\text { erosion in N. A. } \\
\text { I ft. in } 5,000 \text { yrs. } \\
\text { Estimated length of } \\
\text { time to unearth a } \\
\text { carboniferous } \\
\text { fossil. }\end{array}$ & $\begin{array}{l}\text { Relative weight of } \\
\text { ores. Specific } \\
\text { gravity. }\end{array}$ \\
\hline 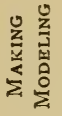 & $\begin{array}{l}\text { Chalk-model cloud } \\
\text { forms. }\end{array}$ & Make shadow-stick. & $\begin{array}{l}\text { Fossil forms. Im- } \\
\text { print leaves in clay } \\
\text { and dry or bake. }\end{array}$ & Crystal forms. \\
\hline 岕 & $\begin{array}{l}\text { Maps showing isotherms, } \\
\text { and course of storms. } \\
\text { Snow crystals. Cloud } \\
\text { forms. }\end{array}$ & $\begin{array}{l}\text { In a large circle } \\
\text { draw radii showing } \\
\text { changing slant of } \\
\text { sun's rays during } \\
\text { month. Moon's } \\
\text { phases. }\end{array}$ & $\begin{array}{l}\text { Fossil plants found } \\
\text { in coal, slate, and } \\
\text { elsewhere. }\end{array}$ & Crystal forms. \\
\hline oี & $\begin{array}{l}\text { Cloud colors. Sky } \\
\text { colors-sunset, sunrise. }\end{array}$ & Color of the planets. & $\begin{array}{l}\text { Color of fossil } \\
\text { remains. }\end{array}$ & $\begin{array}{l}\text { Colors of ores and } \\
\text { metals. }\end{array}$ \\
\hline$\sum_{z}^{u}$ & $\begin{array}{l}\text { The storms for the } \\
\text { month. How to pre- } \\
\text { dict the weather. Why } \\
\text { the wind veers. }\end{array}$ & $\begin{array}{l}\text { Summary of changes } \\
\text { during the month. } \\
\text { Comparison of the } \\
\text { appearance of the } \\
\text { planets; their } \\
\text { apparent motions. }\end{array}$ & $\begin{array}{l}\text { The earth history } \\
\text { suggested by a } \\
\text { fossil plant. }\end{array}$ & $\begin{array}{l}\text { How ores are } \\
\text { smelted. How } \\
\text { ores are mined. } \\
\text { Mineral wealth } \\
\text { compared with } \\
\text { other resources. }\end{array}$ \\
\hline
\end{tabular}

Study of the language forms necessary in all written and oral expression which occurs in the study of all subjects. Choice of words; spelling ; capitals ; pronunciation; punctuation; sentence, subject and predicate; paragraph; figures of speech. Function of words -parts of speech. Relations of words.

" Evening Shades are Falling."-Nat. Mus. Course No. 4 .

Elementary Meteorology. -Davis. Aspects of the Earth.Shaler.

Instructions to Voluntary Observers.Weather Bureau.

\begin{tabular}{|c|c|c|}
\hline $\begin{array}{l}\text { "The Evening Star." } \\
\text {-Nat. Mus, } \\
\text { Course No, } \\
\text { "Evening." Nat. } \\
\text { Mus. Course No. } 4 .\end{array}$ & $\begin{array}{l}\text { "God the Lord." } \\
\text {-Nat. Mus. } \\
\text { Course No. 2. }\end{array}$ & \\
\hline $\begin{array}{l}\text { Astronomy with an } \\
\text { Opera Glass.- } \\
\text { Serviss. } \\
\text { Starland.-Ball. } \\
\text { Cowperthwaite's } \\
\text { Planisphere. } \\
\text { - A. Flanagan. }\end{array}$ & $\begin{array}{l}\text { Aspects of the } \\
\text { Earth.-Shaler } \\
\text { The Geological } \\
\text { Story.-Dana. }\end{array}$ & $\begin{array}{l}\text { World of Matter. } \\
\text { - Ballard. } \\
\text { Common Minerals } \\
\text { and Rocks. } \\
\text {-Crosby. } \\
\text { Mineral Resources } \\
\text { of the U. S. (Re- } \\
\text { ports.) Applied } \\
\text { Geology. } \\
\text { - Williams. }\end{array}$ \\
\hline
\end{tabular}


JUNE.

THOUGHT WORK.

\begin{tabular}{|c|c|c|c|c|c|c|}
\hline \multirow[b]{2}{*}{ 哺 } & \multirow{2}{*}{$\frac{\text { Dूं }}{0}$} & ZoöLOGY & \multirow{2}{*}{$\begin{array}{l}\text { Botany } \\
\text { Plant Physiol- } \\
\text { ogy. Passage } \\
\text { of water } \\
\text { through the } \\
\text { plant. }\end{array}$} & \multirow{2}{*}{$\begin{array}{l}\text { GEOGRAPHY } \\
\text { Conditions of } \\
\text { life at this } \\
\text { season. Vari- } \\
\text { ous stages of } \\
\text { crop growth. }\end{array}$} & \multirow{2}{*}{$\begin{array}{l}\text { Prysics } \\
\text { Electricity, } \\
\text { Frictional and } \\
\text { Voltaic. }\end{array}$} & \multirow{2}{*}{$\begin{array}{l}\text { Chemistry } \\
\begin{array}{l}\text { Chemistry of a } \\
\text { battery. }\end{array}\end{array}$} \\
\hline & & $\begin{array}{l}\text { Insect life. Use the } \\
\text { tree as a center for } \\
\text { study. }\end{array}$ & & & & \\
\hline & 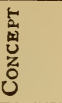 & $\begin{array}{l}\text { Inter-relations of } \\
\text { animals and plants. }\end{array}$ & $\begin{array}{l}\text { Vital functions } \\
\text { in the plant. }\end{array}$ & $\begin{array}{l}\text { Relations of } \\
\text { crops to } \\
\text { geographic } \\
\text { conditions. }\end{array}$ & $\begin{array}{l}\text { Nature of elec. } \\
\text { trical energy. }\end{array}$ & $\begin{array}{l}\text { Chemical } \\
\text { change as a } \\
\text { source of } \\
\text { energy. }\end{array}$ \\
\hline & 芯 & $\begin{array}{l}\text { Butterflies, moths, } \\
\text { bees, beetles, In- } \\
\text { sect eggs. Young } \\
\text { larvæ. Grasshop- } \\
\text { pers. Dragon- } \\
\text { flies. }\end{array}$ & $\begin{array}{l}\text { Different kinds } \\
\text { of seedling } \\
\text { plants. Oak, } \\
\text { maple and ash } \\
\text { seedlings one } \\
\text { year old. Use } \\
\text { sunflower } \\
\text { plant. Study } \\
\text { of flowers. } \\
\end{array}$ & $\begin{array}{l}\text { Pictures showing } \\
\text { growing crops } \\
\text { of various } \\
\text { regions at this } \\
\text { season. }\end{array}$ & $\begin{array}{l}\text { Bottles, wide- } \\
\text { mouthed, or } \\
\text { jars. Small- } \\
\text { sized copper } \\
\text { wire with } \\
\text { insulation. } \\
\text { Glass tubes } \\
\text { and sealing } \\
\text { wax. } \\
\end{array}$ & $\begin{array}{l}\text { Pieces of cop- } \\
\text { per and zinc. } \\
\text { Bottles. Acid. }\end{array}$ \\
\hline & $\mathfrak{n}_{\mathfrak{L}}^{n}$ & $\begin{array}{l}\text { Frame for mount- } \\
\text { ing insects. } \\
\text { Poison bottle. Nets } \\
\text { for insects. Jars } \\
\text { and boxes for in- } \\
\text { sect and larva } \\
\text { cages. }\end{array}$ & $\begin{array}{l}\text { Scales and } \\
\text { weights. Wide- } \\
\text { mouthed } \\
\text { bottles. Grad- } \\
\text { uate for meas- } \\
\text { uring water. }\end{array}$ & $\begin{array}{l}\text { Sand-pans for } \\
\text { modeling maps. } \\
\text { Clay for model- } \\
\text { ing. }\end{array}$ & $\begin{array}{l}\text { Jars or wide- } \\
\text { mouthed bot- } \\
\text { tles. Copper } \\
\text { wire. Tubes. } \\
\text { Zinc and cop- } \\
\text { per plates for } \\
\text { battery. }\end{array}$ & $\begin{array}{l}\text { Battery outfit } \\
\text { used in } \\
\text { Physics. }\end{array}$ \\
\hline \multirow[b]{2}{*}{ 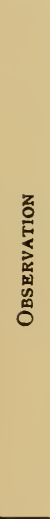 } & דूँ & $\begin{array}{l}\text { Insects that infest } \\
\text { the leaves of plants; } \\
\text { the bark; the wood; } \\
\text { the ground about } \\
\text { the roots; that fre- } \\
\text { quent the flowers. } \\
\text { Depositories of } \\
\text { eggs. Food of } \\
\text { larvæ. }\end{array}$ & $\begin{array}{l}\text { The wilting of } \\
\text { plants. Rela- } \\
\text { tion of leaves } \\
\text { to sunshine. } \\
\text { The flow of } \\
\text { sap. }\end{array}$ & $\begin{array}{l}\text { Character of } \\
\text { vegetation in } \\
\text { different lo } \\
\text { calities. The } \\
\text { environment } \\
\text { and growth of } \\
\text { annuals, bien- } \\
\text { nials, and } \\
\text { perennials. }\end{array}$ & $\begin{array}{l}\text { Examination of } \\
\text { the telephone. } \\
\text { The telegraph. } \\
\text { Trolley street } \\
\text { car. The } \\
\text { dynamo and } \\
\text { electric motor. }\end{array}$ & $\begin{array}{l}\text { Arrangement } \\
\text { of batteries in } \\
\text { a telegraph } \\
\text { office. In } \\
\text { telephone } \\
\text { central. }\end{array}$ \\
\hline & 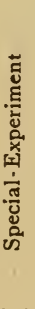 & $\begin{array}{l}\text { Insect mounting. } \\
\text { Modes of flight; } \\
\text { of walking; of se- } \\
\text { curing food; of } \\
\text { eating. Hatching } \\
\text { of insect eggs. }\end{array}$ & $\begin{array}{l}\text { Determine } \\
\text { amount of } \\
\text { water trans- } \\
\text { pired by a } \\
\text { seedling oak, } \\
\text { maple, ash or } \\
\text { sunflower. } \\
\text { Place in wide- } \\
\text { mouthed } \\
\text { bottles in soil } \\
\text { saturated with } \\
\text { water. See } \\
\text { Nature Study } \\
\text { for June. }\end{array}$ & $\begin{array}{l}\text { Trace on } \\
\text { weather maps } \\
\text { the areas of } \\
\text { the various } \\
\text { crops. Note } \\
\text { the isotherms } \\
\text { crossing each } \\
\text { area. }\end{array}$ & $\begin{array}{l}\text { Use glass rod } \\
\text { and sealing } \\
\text { wax and cloth } \\
\text { to develop } \\
\text { electricity. } \\
\text { Connect bat- } \\
\text { tery with small } \\
\text { door bell. } \\
\text { Test the current } \\
\text { with galvano- } \\
\text { meter. See } \\
\text { Nature } \\
\text { Study, p. } 4 \text { r6. }\end{array}$ & $\begin{array}{l}\text { Observe the } \\
\text { chemical } \\
\text { action in a } \\
\text { simple zinc } \\
\text { and copper } \\
\text { battery. See } \\
\text { Nature } \\
\text { Study, p. } 4 \text { I5. } \\
\end{array}$ \\
\hline \multicolumn{2}{|c|}{ 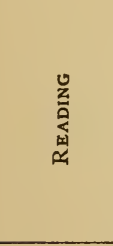 } & $\begin{array}{l}\text { Wings busy and } \\
\text { sober. (I) Flying } \\
\text { bugs and walking } \\
\text { sticks. (I) Wings } \\
\text { of gossamer and } \\
\text { gold. (I) Fruit } \\
\text { and grain destroy- } \\
\text { ers. (I) }\end{array}$ & $\begin{array}{l}\text { Song and Hymn } \\
\text { of Garden and } \\
\text { Wood. (2) } \\
\text { The Sexes of } \\
\text { Plants. (3) } \\
\text { The Arrange- } \\
\text { ment of Leaves. } \\
\text { (3) Hidden } \\
\text { Flowers. (3) }\end{array}$ & $\begin{array}{l}\text { The Central } \\
\text { Plain and } \\
\text { Eastern High- } \\
\text { lands. (4) } \\
\text { The Great } \\
\text { Northwest. (4) } \\
\text { Mexican } \\
\text { Farming and } \\
\text { Mining (4) }\end{array}$ & $\begin{array}{l}\text { Electricity } \\
\text { the Science of } \\
\text { the Igth cen- } \\
\text { tury, chap. I } \\
\text { (Humboldt } \\
\text { Lib., No. I48). } \\
\text { Ibid., chap. } \\
\text { ii, Part II. } \\
\text { Ibid., con- } \\
\text { cluding } \\
\text { chapter. }\end{array}$ & $\begin{array}{l}\text { Electricity the } \\
\text { Science of the } \\
\text { Igth century, } \\
\text { pp. } 79 \text { and } 84 .\end{array}$ \\
\hline & & $\begin{array}{l}\text { Birds in Spring. ( } x \text { ) } \\
\text { Tom. ( } 1 \text { ) Birds at } \\
\text { Dawn. (2) The } \\
\text { Rochester Robin. } \\
\text { (2) }\end{array}$ & $\begin{array}{l}\text { The Ivy Green. } \\
\text {-Dickens. } \\
\text { My Window } \\
\text { Ivy.-Mary } \\
\text { Mapes Dodge. } \\
\text { The Birch Tree. } \\
\text { - Lowell. }\end{array}$ & $\begin{array}{l}\text { To the Dande- } \\
\text { lion.-Lozvell. } \\
\text { In Stacking } \\
\text { Time.-Gar. } \\
\text { land. } \\
\text { Color in the } \\
\text { Wheat.-Gar- } \\
\text { land. } \\
\text { Corn Shadows. } \\
\text { Garland. }\end{array}$ & $\begin{array}{l}\text { Spring.- } \\
\text { Holmes. } \\
\text { Lines on Re- } \\
\text { visiting the } \\
\text { Country.- } \\
\text { Bryant. }\end{array}$ & $\begin{array}{l}\text { After a Tem- } \\
\text { pest. - Bryant. } \\
\text { Summer Wind. } \\
\text {-Bryant. } \\
\text { June.-Bryant. }\end{array}$ \\
\hline
\end{tabular}


JUNE.

THOUGHT WORK - Continued.

\begin{tabular}{|c|c|c|c|c|c|}
\hline \multirow{2}{*}{ 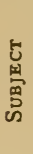 } & ర్ల & METEOROLOGY & Astronomy & GeologY & MINERALOGY \\
\hline & 荧 & $\begin{array}{l}\text { Thunder-storms. } \\
\text { Lighıning. }\end{array}$ & Summer solstice. & $\begin{array}{l}\text { Fieldwork. } \\
\text { Erosion. }\end{array}$ & $\begin{array}{l}\text { Mechanical con. } \\
\text { stituents of soil. }\end{array}$ \\
\hline \multicolumn{2}{|c|}{ 造 } & $\begin{array}{l}\text { Electrical conditions of } \\
\text { earth and air. }\end{array}$ & $\begin{array}{l}\text { Relations of earth } \\
\text { to sun. }\end{array}$ & $\begin{array}{l}\text { Modification of } \\
\text { earth forms. }\end{array}$ & $\begin{array}{l}\text { Relation of soil con- } \\
\text { stituents to fer- } \\
\text { tillity. }\end{array}$ \\
\hline \multicolumn{2}{|c|}{ 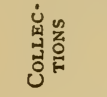 } & Weather Maps. & & $\begin{array}{l}\text { Specimens of rock } \\
\text { showing weather- } \\
\text { ing and wearing. }\end{array}$ & $\begin{array}{l}\text { Various specimens } \\
\text { of soils. }\end{array}$ \\
\hline \multicolumn{2}{|c|}{ 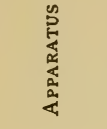 } & $\begin{array}{l}\text { Thermometer. Barome- } \\
\text { ter. Hygrometer. } \\
\text { Rain-guage. Wind } \\
\text { Vane. }\end{array}$ & $\begin{array}{l}\text { Shadow-stick. } \\
\text { Brass protractor. }\end{array}$ & $\begin{array}{l}\text { Trays or boxes for } \\
\text { specimens. }\end{array}$ & Boxes for soils. \\
\hline \multirow{2}{*}{ 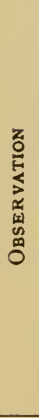 } & ॠँّ & $\begin{array}{l}\text { Formation of thunder } \\
\text { clouds. Character of } \\
\text { lightning flashes. } \\
\text { Examine trees struck } \\
\text { by lightning. Charac- } \\
\text { ter of the weather } \\
\text { before and after such } \\
\text { storms. }\end{array}$ & $\begin{array}{l}\text { Position of sun on } \\
\text { meridian. Note } \\
\text { noon shadows. } \\
\text { Position of the sun } \\
\text { on the horizon. } \\
\text { Change in day's } \\
\text { length. }\end{array}$ & $\begin{array}{l}\text { Visit lake or river } \\
\text { shore. Formation } \\
\text { of bars. Wearing } \\
\text { of banks. }\end{array}$ & $\begin{array}{l}\text { Soils producing } \\
\text { different kinds of } \\
\text { plants. Where } \\
\text { the healthiest } \\
\text { plants are pro- } \\
\text { duced. }\end{array}$ \\
\hline & 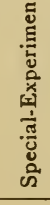 & $\begin{array}{l}\text { Note the average daily } \\
\text { temperature best } \\
\text { suited for planted } \\
\text { growth. Note amount } \\
\text { of rainfall received. }\end{array}$ & $\begin{array}{l}\text { Compare the area } \\
\text { covered by a } \\
\text { given volume of } \\
\text { sunshine with the } \\
\text { area covered by } \\
\text { the same volume } \\
\text { in previous months. }\end{array}$ & $\begin{array}{l}\text { Collect specimens } \\
\text { showing various } \\
\text { phases and stages } \\
\text { of erosion. }\end{array}$ & $\begin{array}{l}\text { By means of sieves, } \\
\text { find the amount of } \\
\text { material, fine, } \\
\text { medium and } \\
\text { coarse, in different } \\
\text { samples of soil. }\end{array}$ \\
\hline \multicolumn{2}{|c|}{ 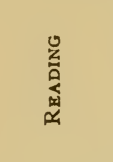 } & $\begin{array}{l}\text { First Book in Geology, } \\
\text { pp. 56-66. }- \text { Shaler. } \\
\text { Ibid., pp. } 98 \text { ff. }\end{array}$ & $\begin{array}{l}\text { Illustrated Lectures } \\
\text { in Astronomy.- } \\
\text { The Oxford } \\
\text { Handy Helps. } \\
\text { The Storyland of } \\
\text { the Stars.- } \\
\text { Mara Pratt. }\end{array}$ & $\begin{array}{l}\text { First Book in } \\
\text { Geology, pp. } \\
\text { 107-130.-Shaler. }\end{array}$ & $\begin{array}{l}\text { First Book in } \\
\text { Geology, pp. } 1-46 . \\
\text {-Shaler. }\end{array}$ \\
\hline \multicolumn{2}{|c|}{ 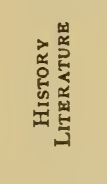 } & $\begin{array}{l}\text { The West Wind.-Gar- } \\
\text { land. } \\
\text { Song of the Winds.- } \\
\text { Garland. } \\
\text { Spring Rains.-Gar. } \\
\text { land. }\end{array}$ & $\begin{array}{l}\text { Sundown.-Gar- } \\
\text { land. } \\
\text { Drought.-Gar- } \\
\text { land. } \\
\text { The Noonday Plain. } \\
\text { Moonlight.- } \\
\text { Longfellow. }\end{array}$ & $\begin{array}{l}\text { The Gladness of } \\
\text { Nature.-Bryant. } \\
\text { A Summer Ramble. } \\
\text { - Bryant. }\end{array}$ & $\begin{array}{l}\text { Plowing. } \\
\text { Earth.-Brland. }\end{array}$ \\
\hline
\end{tabular}

A true announcement of the law of creation, if a man were found worthy to declare it, would carry art up into the kingdom of nature, and destroy its separate and contrasted existence. The fountains of invention and beauty in modern society are all but dried up. ... Now men do not see nature to be beautiful and they go to make a statue which shall be.-Emr Rson, Essay on Art. 
JUNE.

FORM WORK.

\begin{tabular}{|c|c|c|c|c|c|}
\hline & ZoöLOGY & Botany & Geology & Physics & Chemistry \\
\hline 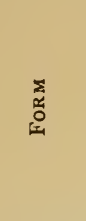 & $\begin{array}{l}\text { Form of insect } \\
\text { bodies. Meaning } \\
\text { of the various forms. } \\
\text { Advantage in loco- } \\
\text { motion, walking } \\
\text { and flight. }\end{array}$ & $\begin{array}{l}\text { Forms assumed } \\
\text { by tree tops. } \\
\text { Study form as } \\
\text { determined } \\
\text { by bud devel- } \\
\text { opment, and } \\
\text { angle of } \\
\text { branches. } \\
\text { Adaptation of } \\
\text { leaf forms. }\end{array}$ & $\begin{array}{l}\text { Forms of the } \\
\text { various crop } \\
\text { areas. }\end{array}$ & $\begin{array}{l}\text { Most economical } \\
\text { forms in con- } \\
\text { struction of } \\
\text { apparatus. }\end{array}$ & $\begin{array}{l}\text { Most economical } \\
\text { forms of zinc } \\
\text { and carbons or } \\
\text { copper used in } \\
\text { batteries. }\end{array}$ \\
\hline 㶵 & $\begin{array}{l}\text { Varieties of insect } \\
\text { life. Number that } \\
\text { live on the leaves; } \\
\text { that deposit eggs } \\
\text { on the leaves; in } \\
\text { the twigs; in the } \\
\text { ground. Number } \\
\text { different kinds of } \\
\text { ground insects. }\end{array}$ & $\begin{array}{l}\text { Growth of twigs } \\
\text { per week. Lat- } \\
\text { eral and ter- } \\
\text { minal growth } \\
\text { compared. } \\
\text { Leaf area esti- } \\
\text { mated from } \\
\text { measurement. } \\
\text { Am't of water } \\
\text { transpired by } \\
\text { an ordinary } \\
\text { tree. }\end{array}$ & $\begin{array}{l}\text { Comparison of } \\
\text { deltas and } \\
\text { other areas } \\
\text { bearing upon } \\
\text { the amount of } \\
\text { erosion in vari- } \\
\text { ous places. }\end{array}$ & $\begin{array}{l}\text { Measurements } \\
\text { necessary in } \\
\text { various appara- } \\
\text { tus needed. }\end{array}$ & $\begin{array}{l}\text { Measurements } \\
\text { needed in bat- } \\
\text { tery construc- } \\
\text { tion. }\end{array}$ \\
\hline 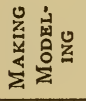 & $\begin{array}{l}\text { Model insect forms. } \\
\text { Forms of eggs- } \\
\text { enlarged. }\end{array}$ & $\begin{array}{l}\text { Forms of leaves } \\
\text { modeled. }\end{array}$ & $\begin{array}{l}\text { Maps showing } \\
\text { distribution of } \\
\text { river systems, } \\
\text { slopes, etc. }\end{array}$ & $\begin{array}{l}\text { Making of ap- } \\
\text { paratus. }\end{array}$ & $\begin{array}{l}\text { Making of bat- } \\
\text { teries. }\end{array}$ \\
\hline 㟧 & $\begin{array}{l}\text { Drawing of insects } \\
\text { showing structure } \\
\text { of parts. }\end{array}$ & $\begin{array}{l}\text { Drawing of tree } \\
\text { forms, Forms } \\
\text { of leaves. } \\
\text { Forms of early } \\
\text { forming fruit. }\end{array}$ & $\begin{array}{l}\text { Maps showing } \\
\text { distribution of } \\
\text { river systems. } \\
\text { Location of } \\
\text { deltas and } \\
\text { other features } \\
\text { relating to ero- } \\
\text { sion. }\end{array}$ & $\begin{array}{l}\text { Drawing of ap- } \\
\text { paratus show- } \\
\text { ing connec- } \\
\text { tions necessary } \\
\text { for various } \\
\text { purposes. }\end{array}$ & $\begin{array}{l}\text { Drawing of bat } \\
\text { teries showing } \\
\text { connections } \\
\text { and relations } \\
\text { of parts. }\end{array}$ \\
\hline 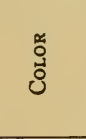 & $\begin{array}{l}\text { Painting of butter- } \\
\text { flies, moths and } \\
\text { other insects. }\end{array}$ & $\begin{array}{l}\text { Landscape } \\
\text { work. Trees, } \\
\text { showing } \\
\text { change of foli- } \\
\text { age. Leaves. }\end{array}$ & $\begin{array}{l}\text { Coloration of } \\
\text { maps showing } \\
\text { relief, slopes, } \\
\text { valleys and all } \\
\text { features of } \\
\text { erosion. }\end{array}$ & & \\
\hline 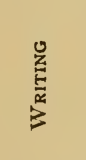 & $\begin{array}{l}\text { How insects fly. } \\
\text { How insects walk. } \\
\text { How insects eat. } \\
\text { How insects are } \\
\text { dependent upon } \\
\text { plants. }\end{array}$ & $\begin{array}{l}\text { The dependence } \\
\text { of plants upon } \\
\text { insects. Water } \\
\text { in plant life. }\end{array}$ & $\begin{array}{l}\text { Relation of val- } \\
\text { leys to the set- } \\
\text { tlement of the } \\
\text { country. Effect } \\
\text { of mountains } \\
\text { upon settle- } \\
\text { inent. }\end{array}$ & $\begin{array}{l}\text { Electricity com- } \\
\text { pared with } \\
\text { steam power. }\end{array}$ & $\begin{array}{l}\text { Effects of chem- } \\
\text { ical changes in } \\
\text { a battery com- } \\
\text { pared wtth ef- } \\
\text { fects of chemi- } \\
\text { cal changes in } \\
\text { combustion. }\end{array}$ \\
\hline
\end{tabular}

The study of thought expression through language. The limits of the sentence. The phrase. Technical terms as needed. Choice of words; spelling; capitals; pronunciation; punctuation; sentence; paragraph; figures of speech.

"The Humble Bee,"|"Summer | "A Mid-Sum- "The Light that " Woodnotes,"

"Summer, Riv- "

ज) Riverside Song

Book.

erside Song

Book.

Our Common In-

Trees of N. A.

sects.-Packard. -Apgar.

Half-Hours with In- Physiological

sects.-Packard.

Botany.-

Comstock's Ento-

mology. Comstock

Gray.

Pub. Co., Ithaca,

N. Y.

Distribution of Animals and Plants. (Humboldt Lib.

Recreations in Botany.Creevy.

Flowers, Fruits and Leaves.Lubbock. No. 64.)

(Humboldt mer Song, Song Book.

Earth and Man. -Guyot.

The Earth's History.Roberts.

Handbook of Commercial Geography. Chisholm. Aspects of the Earth.Lib. Nos. Shaler. is felt," Riv- " Riverside erside Song Song Book. Book.

Electricity the Science of the
Nineteenth enth Century.(Humboldt Lib. Nos. x 48-9.) The Electric Llght._Ibid., No. II9. Modern Views of Electricity. - Lodge.

Force and Enro6.)

Lessons in Electricity. - Tyn . dall ( $H u m$. boldt Lib.) No. 8 .) The Electric Light.-Ibid., No. $x$ I9. I6I-2.) 
JUNE.

FORM WORK.-Continued.

\begin{tabular}{|c|c|c|c|c|}
\hline & METEOROLOGY & ASTRONOMY & Geology & Mineralogy \\
\hline 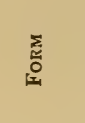 & $\begin{array}{l}\text { Forms of clouds at differ- } \\
\text { ent times in the day. } \\
\text { Form of thunder- } \\
\text { clouds. }\end{array}$ & $\begin{array}{l}\text { Form of shadow- } \\
\text { stick. Angles } \\
\text { made by sun's rays } \\
\text { at different } \\
\text { seasons. }\end{array}$ & $\begin{array}{l}\text { Forms made by } \\
\text { erosion due to } \\
\text { slope, hardness of } \\
\text { material and } \\
\text { amount of water. }\end{array}$ & \\
\hline 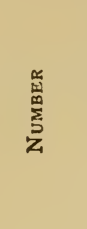 & $\begin{array}{l}\text { Rainfall ; rainy, cloudy } \\
\text { and clear days com- } \\
\text { pared with previous } \\
\text { month. }\end{array}$ & $\begin{array}{l}\text { Angle of noon rays } \\
\text { compared with } \\
\text { preceding months. } \\
\text { Day's length com- } \\
\text { pared. Area cov- } \\
\text { ered by a given } \\
\text { volume of sunshine } \\
\text { compared with } \\
\text { similar areas in } \\
\text { preceding months. }\end{array}$ & $\begin{array}{l}\text { Estimate from } \\
\text { measurements the } \\
\text { amount of silt in } \\
\text { suspension in } \\
\text { different samples of } \\
\text { water. }\end{array}$ & $\begin{array}{l}\text { Various mechani- } \\
\text { cal constituents of } \\
\text { soils compared. } \\
\text { Proper ratio of } \\
\text { different constitu- } \\
\text { ents for plant life. }\end{array}$ \\
\hline 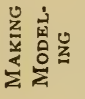 & $\begin{array}{l}\text { Chalk-modeling of } \\
\text { cloud-forms. Thun- } \\
\text { der-clouds. }\end{array}$ & $\begin{array}{l}\text { Making of shadow- } \\
\text { stick. }\end{array}$ & $\begin{array}{l}\text { Sand-models of } \\
\text { eroded districts ob- } \\
\text { served. }\end{array}$ & $\begin{array}{l}\text { Making of sieves } \\
\text { and other necessary } \\
\text { apparatus. }\end{array}$ \\
\hline 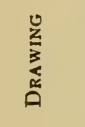 & $\begin{array}{l}\text { Maps showing distribu- } \\
\text { tion of rainfall and } \\
\text { course of isotherms. }\end{array}$ & $\begin{array}{l}\text { Drawings showing } \\
\text { slant of sun's rays } \\
\text { at noon for the } \\
\text { different months. }\end{array}$ & $\begin{array}{l}\text { Drawings showing } \\
\text { course of streams, } \\
\text { of lake shore and } \\
\text { other features of } \\
\text { erosion. }\end{array}$ & $\begin{array}{l}\text { Drawing of ap- } \\
\text { paratus. }\end{array}$ \\
\hline ô & $\begin{array}{l}\text { Sky colors at different } \\
\text { times of day. }\end{array}$ & & $\begin{array}{l}\text { Landscape work } \\
\text { showing features of } \\
\text { erosion. }\end{array}$ & $\begin{array}{l}\text { Landscape work } \\
\text { showing colors due } \\
\text { to differences in } \\
\text { soil. }\end{array}$ \\
\hline$\underset{z}{\underline{Z}}$ & $\begin{array}{l}\text { Description of a thun- } \\
\text { der-storm. }\end{array}$ & $\begin{array}{l}\text { The apparent course } \\
\text { of the sun during } \\
\text { the year. }\end{array}$ & $\begin{array}{l}\text { Describe changes } \\
\text { witnessed by } \\
\text { erosion. }\end{array}$ & $\begin{array}{l}\text { Relative value of } \\
\text { different soils. }\end{array}$ \\
\hline 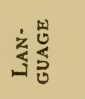 & $\begin{array}{l}\text { The study of thought } \\
\text { phrase. Technical terms } \\
\text { punctuation; sentence; }\end{array}$ & $\begin{array}{l}\text { as needed. Choice o } \\
\text { paragraph; figures of }\end{array}$ & $\begin{array}{l}\text { language. The limits } \\
\text { of words; spelling; ca } \\
\text { f speech. }\end{array}$ & $\begin{array}{l}\text { of the sentence. The } \\
\text { pitals; pronunciation; }\end{array}$ \\
\hline 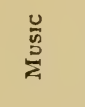 & $\begin{array}{l}\text { "There is Music in the } \\
\text { Air," Riverside Song } \\
\text { Book. }\end{array}$ & $\begin{array}{l}\text { "Softly Now the } \\
\text { Light of Day,", } \\
\text { Riverside Song } \\
\text { Book. }\end{array}$ & $\begin{array}{l}\text { "Stars of the Sum- } \\
\text { mer Night," Riv- } \\
\text { erside Song Book. }\end{array}$ & $\begin{array}{l}\text { "The Harp at } \mathrm{Na-} \\
\text { ture's Advent } \\
\text { Strung," River- } \\
\text { side Song Book. }\end{array}$ \\
\hline 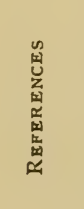 & $\begin{array}{l}\text { Elements of Meteor- } \\
\text { ology.-Davis. } \\
\text { Instructions to Volun- } \\
\text { tary Observers.- } \\
\text { Weather Bureau. } \\
\text { Lightning. Thunder and } \\
\text { Lightning Conductors. } \\
\text { - (Humboldt Lib. } \\
\text { No. r39.) }\end{array}$ & $\begin{array}{l}\text { Starland.-Ball. } \\
\text { The Sun.-(Hum- } \\
\text { boldt Lib. No. 49.) } \\
\text { Romance of Astron- } \\
\text { omy.-Ibid., } \\
\text { No. 2o. } \\
\text { The Wonders of the } \\
\text { Heavens.-Ibid., } \\
\text { No. r4. }\end{array}$ & $\begin{array}{l}\text { Aspects of the } \\
\text { Earth.-Shaler. } \\
\text { Town Geology.- } \\
\text { Kingsley. } \\
\text { The Earth's His- } \\
\text { tory.-Roberts. }\end{array}$ & $\begin{array}{l}\text { Applied Geology.- } \\
\text { Williams. } \\
\text { The World of } \\
\text { Matter.-Ballard. } \\
\text { Crosby's Tables. }\end{array}$ \\
\hline
\end{tabular}




\section{MINUTES OF MEETINGS HELD AT ATLANTA, GA., FEBRUARY 22-25, 1904.}

\section{(CONVENTION HALL, PIEDMONT HOTEL.)}

Four sessions of the Society were held at Atlanta. In the absence of President Jackman, Professor Reuben P. Halleck was chosen chairman, and conducted the discussions and business with marked acceptability.

The first session was held, as appointed, at 4 o'clock P. M., on Monday, February 22. The entire time was devoted to the discussion of Dr. John Dewey's paper on "The Relation of Theory to Practice in Education." This paper stirred up a good deal of vigorous thinking, and aroused, perhaps, more than the usual interest both within and outside the membership of the Society. The discussion was highly valuable in that it revealed the different points of view and methods of attacking a problem by many different persons whose aims are common, but who are often working under widely different conditions. It was found necessary to limit the speakers to five minutes each, and allow no person to speak twice as long as any who had not yet spoken wished the floor.

The meeting set for Wednesday (February 24) was changed from $2: 30$ P. M. to $5: 30$ P. M. This was to avoid conflict with section meetings of the Department of Superintendence, in which most of the members were interested.

The Monday evening meeting proved to be well attended, and there was close and progressive discussion of Dr. Dewey's paper. At this meeting there was an informal consideration of what work the Society ought to take up next. The following lines were suggested:

Charles DeGarmo: Since many of us are deeply interested in the preparation of teachers for secondary education, it might be well to go to that field.

F. M. McMurry: It would be a good plan to have a thoroughgoing discussion of what is "scientific method" in the study of education.

SAmuel T. Dutton: (I) The field of the kindergarten and primary school; (2) how conserve the benefits of school education for adult life? 
Stratton D. Brooks: The question of admission to the university without examination.

A. Kaswell Ellis: Take one of our educational problems and make a thoroughgoing scientific treatment of it.

GRANT KARR: Define the psychological nature of the common-school subjects.

J. Stanley Brown: The time element as it affects the elementary, secondary, and college courses. The six-year course for the high school.

Other suggestions were offered, but were to be made more definite and sent to the Secretary.

On Wednesday at 5 P. M., at the regular business meeting the following officers and members of the Executive Committee were chosen :

President-Professor Wilbur S. Jackman, College of Education, University of Chicago (continued another year).

Secretary-Treasurer - Manfred J. Holmes, Illinois State Normal University, Normal, Ill.

Memoers of the Executive Committee, to serve for two years - Charles A. McMurry, State Normal School, DeKalb, Ill.; Reuben Post Halleck, Male High School, Louisville, Ky.

A motion was carried to appropriate fifty dollars $(\$ 50)$ for the Secretary's expenses during the past year.

A motion was carried to allow the Secretary one hundred and fifty dollars ( $\left.\$ \mathrm{I}_{50}\right)$ for expenses; provided, that such sum remain in the treasury after all other indebtedness of the Society has been discharged.

The discussion of Miss Brooks's paper on "The Relation of Theory to Practice in City Training Schools" brought out some helpful comparisons as to how different cities are trying to supply their schools with trained teachers. This discussion also suggested the question of having a few leaders of discussion well prepared beforehand, and ready to do justice to the paper discussed.

On Thursday, at 9 A. M., the following-named persons were elected to active membership:

Ezra W. Benedict, principal of high school, Warrensburg, N. Y.

Sarah C. Brooks, principal of Teachers' Training School, Baltimore, Md.

Edwin C. Broome, superintendent of schools, Rahway, N. J.

John F. Brown, professor in education, State University, Iowa City, Ia.

J. Stanley Brown, superintendent of Township High School, Joliet, Ill. 
W. T. Carrington, state superintendent of public schools, Jefferson City, Mo. Charles E. Chadsey, assistant superintendent of schools, Denver, Colo.

J. M. H. Frederick, superintendent of schools, Lakewood, O.

Albert Ross Hill, dean of Missouri Teachers' College, Columbia, Mo.

Homer P. Lewis, superintendent of schools, Worcester, Mass.

Elizabeth Mavity, Illinois State Normal Universty, Normal, Ill.

George A. Newton, superintendent of schools, Greenville, Tex.

James J. Sheppard, principal of High School of Commerce, New York, N. Y. Waite A. Shoemaker, State Normal School, St. Cloud, Minn.

Elmer W. Walker, superintendent of State School for the Deaf, Delavan, Wis.

After informal consideration of plans and conduct of the Society, it was moved and carried that the topic for the next YEArвook be taken from the field of secondary education.

Annual financial statements will be printed in Part I of each YEARBOoK, published regularly for the February meeting. 


\section{LIST OF ACTIVE MEMBERS.}

Edwin A. Alderman, president of Tulane University, New Orleans, La. Zonia Baber, School of Education, University of Chicago, Chicago, Ill. Frank Bachman, Normal College, Athens, O.

C. M. Bardwell, Aurora, Ill.

R. H. Beggs, Whittier School, Denver, Colo.

Ezra W. Benedict, principal of high school, Warrensburg, N. Y.

Frank G. Blair, State Normal School, Charleston, Ill.

Frederick Bolton, Iowa City, Ia.

Richard G. Boone, Yonkers, N. Y.

E. C. Branson, Normal School, Athens, Ga.

Francis B. Brant, 1637 S. Fifteenth Street, Philadelphia, Pa.

Sarah C. Brooks, principal Teachers' Training School, Baltimore, Md.

Stratton D. Brooks, Mason street, Boston, Mass.

Edwin C. Broome, superintendent of schools, Rahway, N. J.

Elmer E. Brown, University of California, Berkeley, Calif.

George P. Brown, editor, Bloomington, Ill.

John F. Brown, State University, Iowa City, Ia.

J. Stanley Brown, Township High School, Joliet, Ill.

Martin G. Brumbaugh, 3324 Walnut Street, Philadelphia, Pa.

William L. Bryan, University of Indiana, Bloomington, Ind.

George V. Buchanan, 6r4 W. Seventh Street, Sedalia, Mo.

Edward F. Buchner, University of Alabama, University, Ala.

Frederick Burk, State Normal School, San Francisco, Calif.

Jesse D. Burks, 557 W. Twelfth Street, New York, N. Y.

W. H. Burnham, Clark University, Worcester, Mass.

Nicholas Murray Butler, Columbia University, New York, N. Y.

B. C. Caldwell, president of Louisiana State Normal, Natchitoches, La.

W. T. Carrington, state superintendent, Jefferson City, Mo.

Charles E. Chadsey, assistant superintendent of schools, Denver, Colo.

Clarence F. Carroll, Worcester, Mass.

C. P. Cary, state superintendent, Madison, Wis.

E. W. Chubb, Athens, O.

P. P. Claxton, Southern Education Board, Knoxville, Tenn.

David E. Cloyd, II6 Nassau street, New York, N. Y.

John W. Cook, State Normal School, DeKalb, Ill.

William J. Crane, Marshalltown, Ia.

Ellwood I. Cubberly, Leland Stanford Junior University, Palo Alto, Calif. 
Frank M. Darling, 320 W. Sixty-first Place, Chicago, Ill.

William M. Davidson, Topeka, Kan.

Washington S. Dearmont, State Normal School, Cape Girardeau, Mo.

Charles DeGarmo, Cornell University, Ithaca, N. Y.

John Dewey, University of Chicago, Chicago, Ill.

Edwin G. Dexter, State University, Urbana, Ill.

Richard E. Dodge, Columbia University, New York, N. Y.

Newton C. Dougherty, Peoria, Ill.

Augustus S. Downing, One Hundred and Nineteenth Street and Second avenue, New York, N. Y.

F. B. Dressler, University of California, Berkeley, Calif.

Samuel T. Dutton, Columbia University, New York, N. Y.

Charles B. Dyke, Kamehameha School, Honolulu, H. I.

Andrew W. Edson, Park Avenue and Fifty-ninth street, New York, N. Y.

A. Kaswell Ellis, University of Texas, Austin, Tex.

W. H. Elson, Grand Rapids, Mich.

David Felmley, State Normal University, Normal, Ill.

Frank A. Fitzpatrick, Boston, Mass.

George M. Forbes, Rochester University, Rochester, N. Y.

J. M. H. Frederick, superintendent of schools, Lakewood, O.

R. S. Garwood, Marshall, Mich.

Charles B. Gilbert, D. Appleton \& Co., New York, N. Y.

Newell D. Gilbert, DeKalb, Ill.

E. C. Glass, Lynchburg, Va.

John Glotfelter, Emporia, Kan.

J. P. Gordy, Ohio State University, Columbus, O.

James M. Greenwood, Kansas City, Mo.

W. N. Hailman, Ainsworth \& Co., Boston, Mass.

Reuben P. Halleck, Boys' High School, Louisville, Ky.

Rufus H. Halsey, State Normal School, Oshkosh, Wis.

Paul Henry Hanus, Harvard University, Cambridge, Mass.

Ada VanStone Harris, city schools, Rochester, N. Y.

W. H. Hatch, Oak Park, Iil.

Mrs. Josephine W. Heermans, Brunswick Hotel, Kansas City, Mo.

J. W. Henninger, State Normal School, Macomb, Ill.

Walter L. Hervey, 320 Manhattan Avenue, New York, N. Y.

Edgar L. Hewett, Las Vegas. N. M.

Albert R. Hill, Missouri Teachers' College, Columbia, Mo.

M. J. Holmes, State Normal University, Normal, Ill.

W. W. Howe, White Hall, N. Y.

Wilbur S. Jackman, University of Chicago, Chicago, Ill.

J. I. Jegi, State Normal School, Milwaukee, Wis. 
Jeremiah W. Jenks, Cornell University, Ithaca, N. Y.

Lewis H. Jones, State Normal College, Ypsilanti, Mich.

Grant Karr, State Normal School, Oswego, N. Y.

J. A. Keith, Northern Illinois State Normal School, DeKalb, Ill.

John R. Kirk, State Normal School, Kirksville, Mo.

Henry E. Kratz, Calumet, Mich.

Ossian H. Lang, editor, 6r E. Ninth Street, New York, N. Y.

Isabel Lawrence, State Normal School, St. Cloud, Minn.

Homer P. Lewis, superintendent of schools, Worcester, Mass.

George H. Locke, University of Chicago, Chicago, Ill.

Livingston C. Lord, State Normal School, Charleston, Ill.

Charles D. Lowry, 307 Touhy Avenue, Chicago.

Herman T. Luckens, State Normal School, California, Pa.

G. W. A. Luckey, Lincoln, Neb.

President E. O. Lyte, State Normal School, Millersville, Pa.

John A. MacVannel, Columbia University, New York, N. Y.

David R. Major, Columbus, O.

C. E. Mann, St. Charles, Ill.

Frank A. Manny, Ethical Culture Schools, Iog W. Fifty-fourth Street, New York, N. Y.

Elizabeth Mavity, State Normal University, Normal, Ill.

Guy E. Maxwell, State Normal School, Winona, Minn.

William H. Maxwell, superintendent of schools, New York, N. Y.

Charles McKenny, State Normal School, Milwaukee, Wis.

Charles A. McMurry, State Normal School, DeKalb, Ill.

Frank M. McMurry, Teachers College, New York, N. Y.

Israel C. McNeil, State Normal School, West Superior, Wis.

William A. Millis, Crawfordsville, Ind.

J. F. Millspaugh, State Normal School, Los Angeles, Calif.

Paul Monroe, Columbia University, New York, N. Y.

Will S. Monroe, State Normal School, Westfield, Mass.

Ernest C. Moore, University of California, Berkeley, Calif.

Frank Morton, Lowell High School, San Francisco, Calif.

George A. Newton, superintendent of schools, Greenville, Tex.

Theodore B. Noss, State Normal School, California, Pa.

M. V. O'Shea, University of Wisconsin, Madison, Wis.

Simon N. Patten, University of Pennsylvania, Philadelphia, Pa.

John H. Phillips, Birmingham, Ala.

John T. Prince, West Newton, Mass.

J. F. Reigart, 109 W. Fifty-fourth Street, New York, N. Y.

R. R. Reeder, Hastings-on-Hudson, New York.

C. M. Richards, 230 W. One Hundred and Fifth Street, New York, N. Y. 
Emily J. Rice, School of Education, University of Chicago, Chicago, Ill.

R. N. Roark, Kentucky University, Lexington, Ky.

Stuart H. Rowe, 30 Academy Street, New Haven, Conn.

J. E. Russell, Teachers College, New York, N. Y.

Lucy M. Salmon, Poughkeepsie, N. Y.

Howard Sandison, Terre Haute, Ind.

Myron T. Scudder, State Normal School, New Paltz, N. Y.

Levi Seeley, State Normal School, 482 W. State Street, Trenton, N. J.

Burgess Shank, Normal School, Valley City, North Dakota.

James J. Sheppard, High School of Commerce, New York, N. Y.

Waite A. Shoemaker, State Normal School, St. Cloud, Minnesota.

H. W. Shryock, State Normal School, Carbondale, Ill.

Herbert M. Slauson, Ann Arbor, Mich.

David E. Smith, Teachers College, New York, N. Y.

George M. Smith, University of South Dakota, Vermillion, S. D.

Z. X. Snyder, State Normal School, Greeley, Colo.

F. Louis Soldan, Ninth and Locust Streets, St. Louis, Mo.

Edward D. Starbuck, Leland Stanford Junior University, Palo Alto, Calif.

J. W. Stearns, University of Wisconsin, Madison, Wis.

J. R. Street, University of Syracuse, Syracuse, N. Y.

W. S. Sutton, University of Texas, Austin, Tex.

Joseph S. Taylor, 2275 Aqueduct Avenue, University Heights, New York, N. $Y$.

Charles H. Thurber, Ginn \& Co., Boston, Mass.

C. C. VanLiew, State Normal School, Chico, Calif.

James H. VanSickle, Baltimore, Md.

Elmer W. Walker, superintendent of State School for the Deaf, Delavan, Wis.

Sarah J. Walter, Willimantic, Conn.

Samuel Weir, Clarion Normal School, Clarion, Pa.

Guy Montrose Whipple, Cornell University, Ithaca, N. Y.

A. S. Whitney, University of Michigan, Ann Arbor, Mich.

J. J. Wilkinson, Chicago, Ill.

J. M. Wilkinson, State Normal School, Emporia, Kan.

Lightner Witmer, University of Pennsylvania, Philadelphia, Pa.

L. E. Wolfe, San Antonio, Tex.

O. I. Woodley, Menominee, Mich. 






